\title{
Littoral Tales: Lagos
}

by

Fiki Falola

A thesis submitted to the Faculty of Graduate and Post Doctoral Affairs

in partial fulfillment of the requirements for the degree of

\author{
Master of Architecture
}

in

Azrieli School of Architecture \& Urbanism

\author{
Carleton University \\ Ottawa, Canada
}

(C) 2021

Fiki Falola 
"There is no reason for clinging to the doleful prognostications so often uttered with regard to the hopelessness of ever rendering Lagos a fairly healthy city. When its swamps are filled up, when the island is surrounded by a sea wall, when its rainfall is utilised, and its sewage regulated, then Lagos will be sufficiently healthy to become

the proud Queen of West Africa, the greatest

emporium of trade in this part of the continent.' Sir William McGregor, 1901 


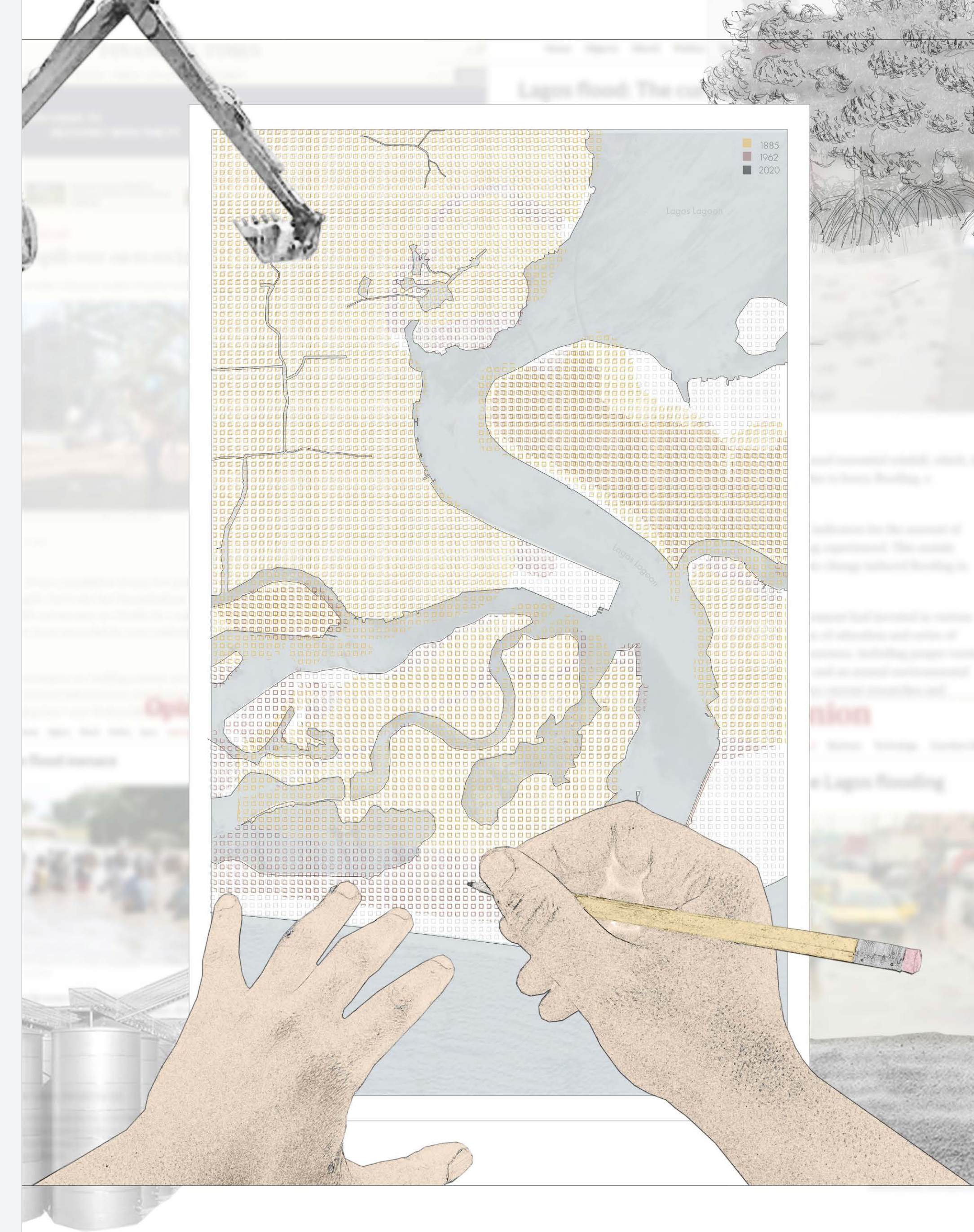


“...With its coastal location and abundant

natural resources, Lagos is ideally positioned to take a leading role in the African economy and become a major global force, especially with a population of 18 million, which is expected to soar

to 25 million by 2015. The gateway to the continent needs a new headquarters. Eko Atlantic is the answer. Rising on land reclaimed from the Atlantic Ocean off Victoria Island in Lagos...It will create prosperity and will be where business gets done."

Eko Atlantic, Developer's Statement, 2012 
This thesis explores speculative interventions along Lagos' Littoral zones woven within complex lavers of land, water, and waste. Subverting the colonial extractive operations of dredging, drilling and draining, it imagines the social construction of space through intervention that aggregate, accumulate and promote adaptation, to changing environmental conditions such as rising water

Drawings, maps, sections and collages at the urban scale are used as tools to explore the geo-historical development of Lagos, beginning with the colonial period. Narrowing into a locality with an industria and military history, this thesis presents some interesting challenges: How do we re-interpret and subvert the colonial ways of understanding land and sea? How might viewing non-human entities as co-creators of architectural space affect the way we design? How can an architectura understanding of the networks of land, water, and waste at the urban scale support speculation around sustainable and community-driven interventions at the human scale of a neighbourhood? 


\section{To my community:}

My brilliant and incredibly insightful advisor Catherine Bonier, without which this would not have been possible. Thank you for inspiring both creativity and rigor throughout my studies and during my thesis.

The academic community which also helped steward my architectural journey—Ozayr Saloojee, Hans Ibelings. Thank you for consistently challenging me.

My friends and family, mom, dad, Joe, thank you for always supporting me and engaging with my ideas.

My colleagues, the faculty at Carleton and beyond-Dr. Taibat Lawanson (who provided specific insights on the city which I could not have googled), Bruno, and all the other people with whom I shared great conversations, thank you.

Espresso...

I now realize I will be completing my masters with many more questions than answers and I am entirely enthusiastic about this. 
CONTENTS

ix $A$ sstract

xi Acknowledgements

xii Contents

xv Method/Tools/Glossary (Old)

xvii Method/Tools/Glossary (New)

PART 1: THE PRESENT: PRECARIOUS POSSIBILITIES

13 Lagos-Appropriating the Sea

PART 2: THE PAST: DREDGE, DRILL, DRAIN

23 Methodolog

39 Methodology I: Mapping

67 Methodology II: Time Phased Sections

77 Methodology III: Exercises in Form Finding

PART 3: THE FUTURE: AGGREGATE, ACCUMULATE, ADAPT

101 The Future: Improvising Ecologies

139 Conclusion: Design as Process

143 List of Maps used in Research

147 List of Figures

153 Endnotes

159 Bibliography 


\section{Environmental}

\section{Operations}

Dredging: A complex process of extracting sediment and relocating it. Despite the many creative possibilities of managing sediment, its potential is often simply relegated to fulfilling commercial objectives such as deepening a channel for a ship or to engineer an architectural development with a waterfront view. ${ }^{1}$

Drilling: The process of extracting the natural resource wealth of one territory and generally transferring it to another

Draining: Refers to the removal of water from wetlands and naturally vegetative areas for sanitary, bacteriological, industrial, or agricultural purposes.

Mapping: A system of representation that allows a unique author to territorialize space, for the purpose of conquest, establishing a "new" settlement on already settled land, or simply to indicate valuable locations for resource shopping.

\section{Habitation}

Urban Planning: A device for rebuilding the city by means of subtracting whatever does not belong in a minority utopic vision.

Wetland: An unproductive parcel of land that collects water and breeds disease. Safe and healthy societies are better suited to $d r y l a n d s$. Whenever possible, wetlands should be eliminated. ${ }^{2}$
Breakwater: A device to subjugate the flow of water in coastal areas where inhabitants are not accustomed to surfing.

Flood: Water with an increased flow that ventures into human occupied spaces, sometimes causing disaster-especially in urbanized areas.

Land Reclamation: The process of creating new land from the sea. Often used as a method to address the issues of land scarcity that come with urbanization, or to re-claim land the ocean has taken away. Completed using the operations of "dredging and draining."

Adaptation: A selectively scaled approach to address environmental concerns by diverting environmental problems from one area to another. 


\section{Habitation and Environmental}

\section{Operations}

Social Construction of Space: The social construction of space is the means by which human and non-human entities use their social and material agency to co-construct space through processes of aggregation, accumulation, and adaptation. Simultaneous with these constructive processes is the actualization of new economic and social systems. This paradigm upholds the belief that the term "social" is inclusive of a multispecies with which humans live and exist interdependently. ${ }^{4}$

Self-Organized Community: Autonomous communities that use

improvisational methods to construct their spaces, often working and

operating within an economy that is not regulated by the government.

Sea Appropriation: The act of altering or extending the boundary between land and water by creating new land from the sea.

Social Media Flood Timeline: A research tool that is used to analyze responses to flood to establish place-based patterns that exist beyond traditional mapping methods/ available information.

Twitter for Geoverse: A technologically advanced version of Twitter that imagines how non-human entities might communicate if they were sentient. Please see Methodology for more info.

Re-swampified: Previously drained wetland areas that return to their natural state of being - swamp

New World Architecture: Unexplored territories, spaces, or areas of dwelling that present opportunities for creating new theories by superimposing pre-existing notions or typologies in unfamiliar situations or habitations.

Aggregate: The practice of combining distinct elements into a whole.

Accumulate: A process of gathering parts over time, which eventually results in a whole.

Rising Water: A name to describe water rising above the threshold most are usually accustomed to.

Tools

Grades of Wetness: An alternative way to represent 2D space, by mean of re-considering the relationship of land and water. Water is usually described as subservient to land using terminology such as flood and land reclamation. Grades of Wetness considers land from the standpoint of water, as possessing different qualities of "wetness" that hold different amounts of water, depending on their geological or vegetative characteristics. ${ }^{6}$ 
1 Dredging Today. "USA: DredgeFest Approaches," September 6, 2012. https://www.dredgingtoday.com/2012/09/06/usa-dredgefestapproaches/.

DredgeFest, an annual symposium, field expedition and speculative design workshop in the USA, defines dredging within the framework of the Anthropocene as a mechanized operation in which underwater sediments are removed/transported from the bottom of lakes, rivers, harbours etc. It is part of a network of activities in which "humans act as intentional and unintentional geologic agents, accelerating and decelerating the movement of silts, sands and clay."

2 Dahl, Thomas E., and Gregory J. Allord. History of Wetlands in the Conterminous United States. U.S. Geological Survey, 1997. This relates to the idea that during the 1700 s wetlands were regarded as obstacles to development, disease ridden, and should be reclaimed for other purposes.

3 Ajibade, Idowu. "Can a Future City Enhance Urban Resilience and Sustainability? A Political Ecology Analysis of Eko Atlantic City, Nigeria." International Journal of Disaster Risk Reduction, Africa's Urban Risk and Resilience, 26 (December 1, 2017): 85-92. https://doi.org/10.1016/j. ijdrr.2017.09.029. On Eko Atlantic, Ajibade argues “'For the most part, the project commodifies not just nature but the idea of adaptation by converting a publicly owned common-pool resource (ocean space and seabed) into a prime estate for capital accumulation. To do this, the 
State allocated the ocean space and seabed to developers in the name of addressing an environmental crisis and then enclosed and privatised this space and the reclaimed land on account of boosting Nigeria's economic growth. This uneven socio-ecological metabolism did not only alter the social relations of property with respect to the ocean, but it erased the people, culture and configuration of economic and non-economic usage that existed in the area."

4 Zárate, Lorena. "They Are Not 'Informal Settlements'-They Are Habitats Made by People." The Nature of Cities (blog), April 26, 2016 https://www.thenatureofcities.com/2016/04/26/they-are-not informal-settlements-they-are-habitats-made-by-people/. This idea was inspired by Lorena Zárate's concept- The Social Production of Habitat which details the production of habitat by people using people-centered processes to create and manage housing, services and community infrastructure. Lorena Zárate, President of Habitat International Coalition critiques the use of the term slum and its variations because it often highlights the negative aspects of such living conditions while ignoring their complexity and the rights of people to produce and manage their own habitats as a fundamental right to the city.

5 The term "New World" was historically used by European navigators to refer to issues concerning the exploration and colonization of the Americas. It was called the New World because previously, most exploration and known land had existed in Africa, Asia, and Europe. The term "New World" here, not to be confused with its historical use is placed in the context of architecture to describe new ground for architectural theorization and exploration that has not previously been rigorously studied or examined.

6 Mathur, Anuradha, and Dilip Da Cunha. Soak: Mumbai in an Estuary New Delhi: Rupa Publications, 2009. In Soak, Dilip and Anuradha imagine Mumbai as an estuary rather than an island they note that an estuary demands gradients not walls, fluid occupancies not defined land uses, negotiated moments not hard edges.

7 Jackson, Steven J. "Rethinking Repair." In Media Technologies: Essays on Communication, Materiality, and Society, 222. MIT Press, 2013. http:// ieeexplore.ieee.org/document/6733973. 


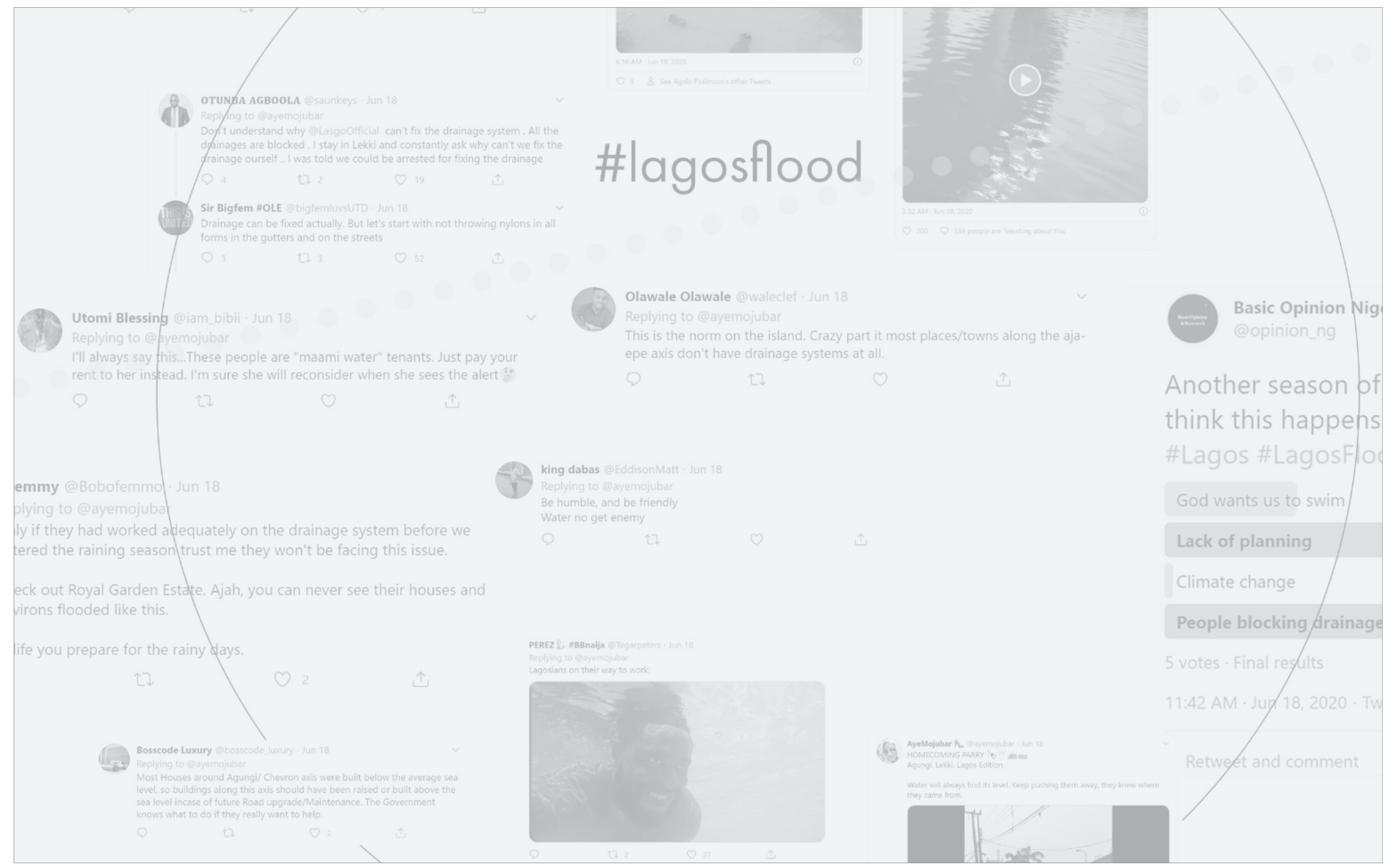




\section{breakwater}

Why does all the sand have to stay on my side? \#flowinterrupted \#westmole

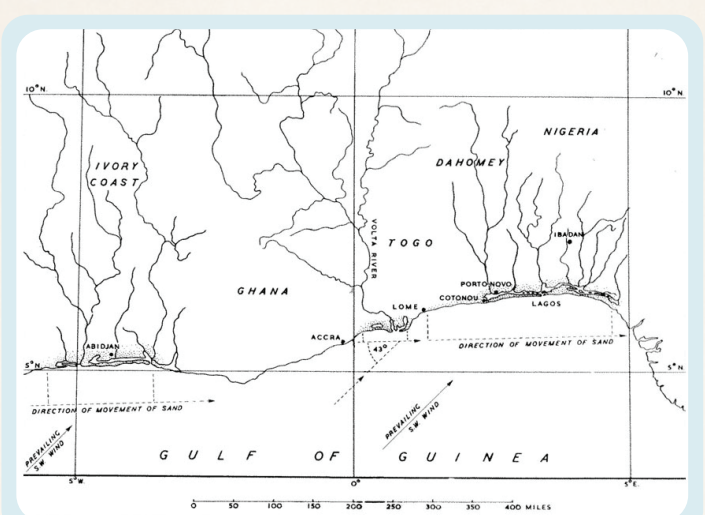

6:22 AM · Jan 12, 1912 · Twitter for Geoverse

5 Retweets $\mathbf{2}$ Likes

0

victoriaisland @queenschoice · 1h

Replying to @wavegoodbye

Intic. Send some over here \#frodingawa

P

20

○ 0 
The urgency of climate change in Lagos and its future as a coastal city, has been rendered a matter of concern ${ }^{7}$ with the launch of Eko Atlantic. Eko Atlantic is a planned development in Lagos built for 250, 000 inhabitants, composed of five million square meters claimed from the Atlantic Ocean. The development was initially built to stop coastal erosion along the shores of Victoria Island, an important business district in the city. The project is composed of two parts: [1] The construction of The Great Wall of Lagos and [2] The construction of a new microcity just beyond Victoria Island.

For the Lagos elite, the construction of Eko Atlantic city is a triumph. The design of the wall is an engineering feat, and the city will have many high-tech features and amenities, positioning it to become a model for the rest of West Africa. Aside, there has been much debate about the environmental impacts of this project and how it will affect neighboring communities. Some experts note that while this new city will be protected, parts of the city beyond the wall will become susceptible to flooding. There is evidence of this already happening, although the developers pride the project on their commitment to sustainability.

"The developers of Eko Atlantic City are committed to creating an environmentally friendly city for the 21st Century. Through planting trees, using energy efficient materials where possible, and wellplanned infrastructure and roads, Eko Atlantic City is ushering in a new city with a green future in mind." 
Amidst this debate, the practice of claiming land in Lagos in the past decade has been rendered increasingly visible. Following the construction of Banana Island in the 80s, an exclusive island for high profile individuals, at the turn of the century many new islands and parcels of sea-appropriated land began appearing on the coastline. This included Orange Island and Gracefield Island, enclaves for habitation that were also created through dredging from the bed of the Lagos Lagoon. There have been many appeals against the dangers of land reclamation because of the adverse effects on the environment, such as reducing coastal resilience in the event of coastal storms, tidal surges and the destruction of nearby ecosystems. Further it is noteworthy that much of the Lagos Metropolitan area is only on average 1-3 metres above sea level (depending on location). As a result, many neighborhoods both along the coast and beyond are susceptible to extreme flooding Despite this, both the government and public-private partnerships desire to claim more land (See Fig. 3). Those in favor of dredging celebrate the greater availability of land it provides for the quickly growing population. ${ }^{8}$ The city, however, is constantly having to battle against coastal erosion. Further, Nigeria's wetlands, the country's natural stronghold against flooding, have been progressively lost through the process of urbanization. ${ }^{?}$

How did we get here? The practice of appropriating land from the sea is not new. Historically, Lagos was mostly water. It was a series of islands, sandbars and mudflats. The first documented alteration of land can be traced to the 19th century. In Earth and its Inhabitants, French geographer, Elisée Reclus notes that, "The island of Lagos, the Auni or
Awani of the natives, lies three miles from the sea, between the arms of the lagoons, the mouth of the Ogun river, and the channel opening seawards. The city occupies a large space on the west side of this marshy land, where the European quarter has been built on ground partly reclaimed from the lagoon." ${ }^{10}$ Further for many coastal cities, fighting the war against the sea has been a historical battle, which often carried with it many political implications depending on where the littoral line (boundary) was drawn, a device Dilip Da Cunha and Anuradha Mathur term in Soak as the “...mos powerful instrument in the European enterprise of mapping that would make the land-sea separation not just a commonly accepted reality, but stark divide., 11

In some ways, Littoral Tales is part of a continuum of the universal story of the many concerted efforts by different engineering and militaristic operations to wage what might be termed the war against the sea, also mirrored in the multi-faceted efforts by the U.S Army Corps of Engineers to tame the Mississippi, as explored in James McPhee's Atchafalaya ${ }^{12}$ This war is further complicated by its position within the capitalistic and colonial enterprise of industrialization, which often involved extracting the wealth of one territory for the external realization of profit (outside of the territory).

In other ways Littoral Tales is a specific and needed story to tel for Lagos because it is a West African city, and because it is situated within a spatial perspective that is absent in many of its historical accounts (further explained in Part 2). 


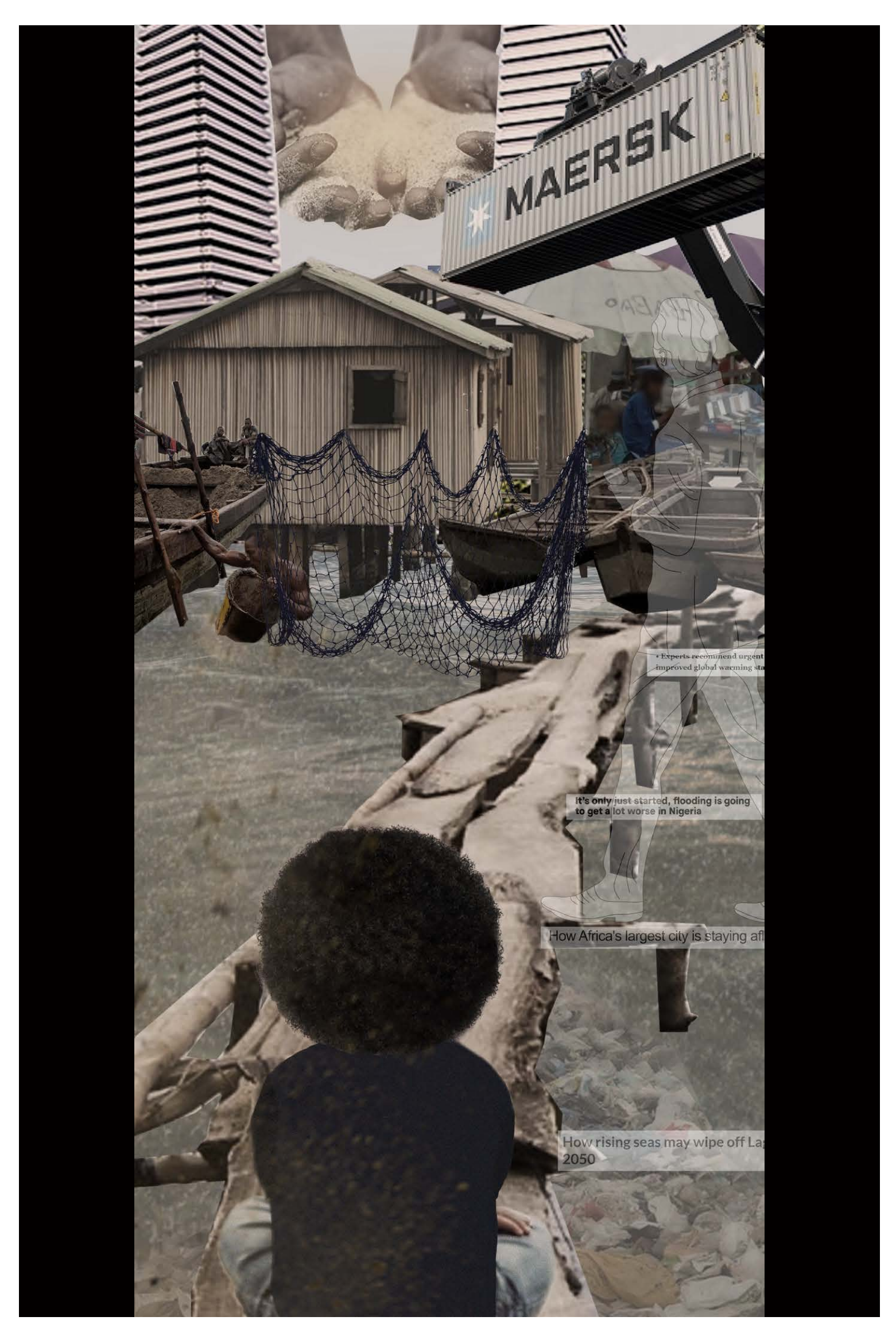


"The fundamental conundrum of Lagos, considered as both paradigm and pathological extreme of the West African city, is its continued existence and productivity in spite of a near-complete absence of those infrastructures, systems, organizations, and amenities that define the word "city" in terms of Western planning methodology. Lagos, as an icon of West African urbanity, inverts every essential characteristic of the so-called modern city. Yet, it is still-for lack of a better word-a city; and one that works."

-Koolhaas, Lagos, Harvard Project on the City (2000)

"If Koolhaas and his colleagues, soaring over the city, can clain that the sight of the traders crammed beneath the Oshodi flyover is 'proof and evidence' that Lagos urbanism is 'one that works', the conclusion is inescapable: in their perspective, it is the city's ability to sustain a market that is the sole signifier of its health...In the 19th century, colonial campaigns aimed to impose new forms of power relations; is the goal of the 21st century exploration nothing more than to celebrate the outcome of existing ones?" 

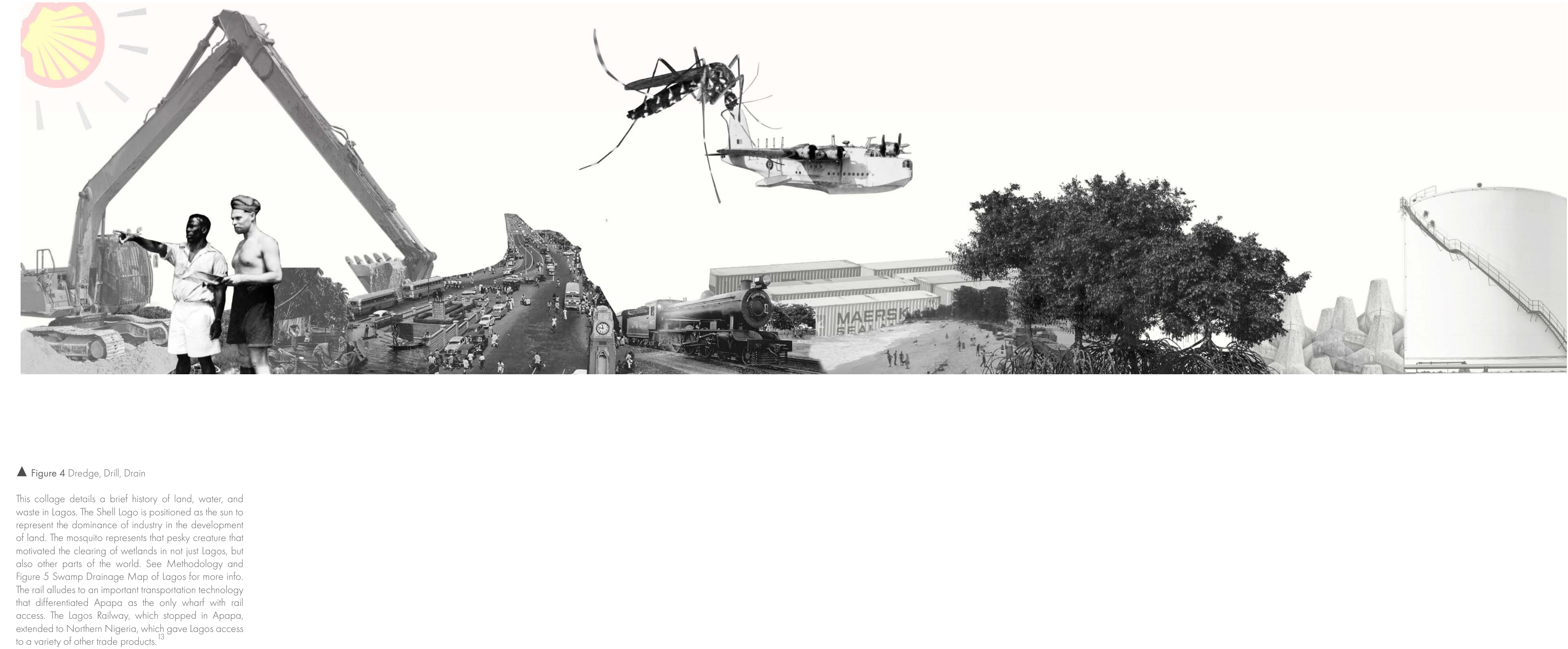
METHODOLOGY

What does it mean for a city to work? Investigating the Past to Understand Space in the Present and Speculate on the Future

This thesis began by investigating the geo-historical development of Lagos, using maps to understand how the city arrived at its presentday conditions: a city with a negotiable population of about fifteen million, widespread environmental issues related to coastal erosion and flooding, and a city of vast socio-economic division. In Postmodern Geographies urbanist and geographer Edward Soja discusses the absence of spatial analysis in critical theory and why it is an important avenue to investigate the subject of power. Soja quotes Michel Foucault’' 'Eye of Power', noting that a history written of spaces, would simultaneously be a history of powers. ${ }^{14}$ Further, Dr. Ademide Adelusi-Adeluyi, whose research focusses on the history of African cities, localizes this argument by noting that the spatial narrative is important because

“...there is a blankness to the space in which historical narratives unfold in West African cities. There is also an anonymity that plagues Lagosians (or ara Eko, as they are known locally) who are not male, titled, or rich... [and narratives usually focus on] ...the political, economic, and social aspects of change through time... [while].. the city, islands, and coastline fade into the background, unengaged and passive in their role as landscape." 15

The history of land in Lagos is one that involves repeatedly claiming land from the sea, draining swamps, building canals, clearing wetlands, 
and subjugating the flow of water. Though seemingly novel because of its position as a West African city, further research of places with colonial histories drew similarities. The pattern involved the development of railway, the clearing of wetlands to make space for industry, or swamp drainage motivated by sanitation/bacteriological ideas.

In History of Wetlands in the Conterminous United States, it is noted that there was a perception in the 1700 s that wetlands were a problem and an obstacle to development. As a result, large scale drainage campaigns ensued to transform wetlands into farmlands and other "productive" land uses. ${ }^{16}$ These practices of altering the landscape which were enabled by advances in technology, enabled the production of specific landscapes, which although they seem fixed, could have had alternate outcomes. Anuradha Mathur and Dilip Da Cunha for example, in their project Soak, imagine Mumbai as an estuary, celebrating the idea of fluid occupancies and accommodating the sea rather than fighting against it with developments such as sea walls. ${ }^{17}$ The theory of Soak is a manifesto that calls for an approach to making peace with the sea, "...gradients not walls, fluid occupancies not defined land uses, negotiated moments not hard edges." ${ }^{18}$ Further, in In Levees that Might Have Been, Richard L. Hindle notes that "The intensively engineered rivers we know today were not inevitable."19 Through exploring a series of levee patents and technologies he provides insights and imaginations of infrastructures that might have resulted in a very different U.S Landscape. ${ }^{20}$ The common thread among these two discussions is the landscapes we see today were by design, including in many cases, the associated environmental problems that accompany them. An archive of forgotten patents from
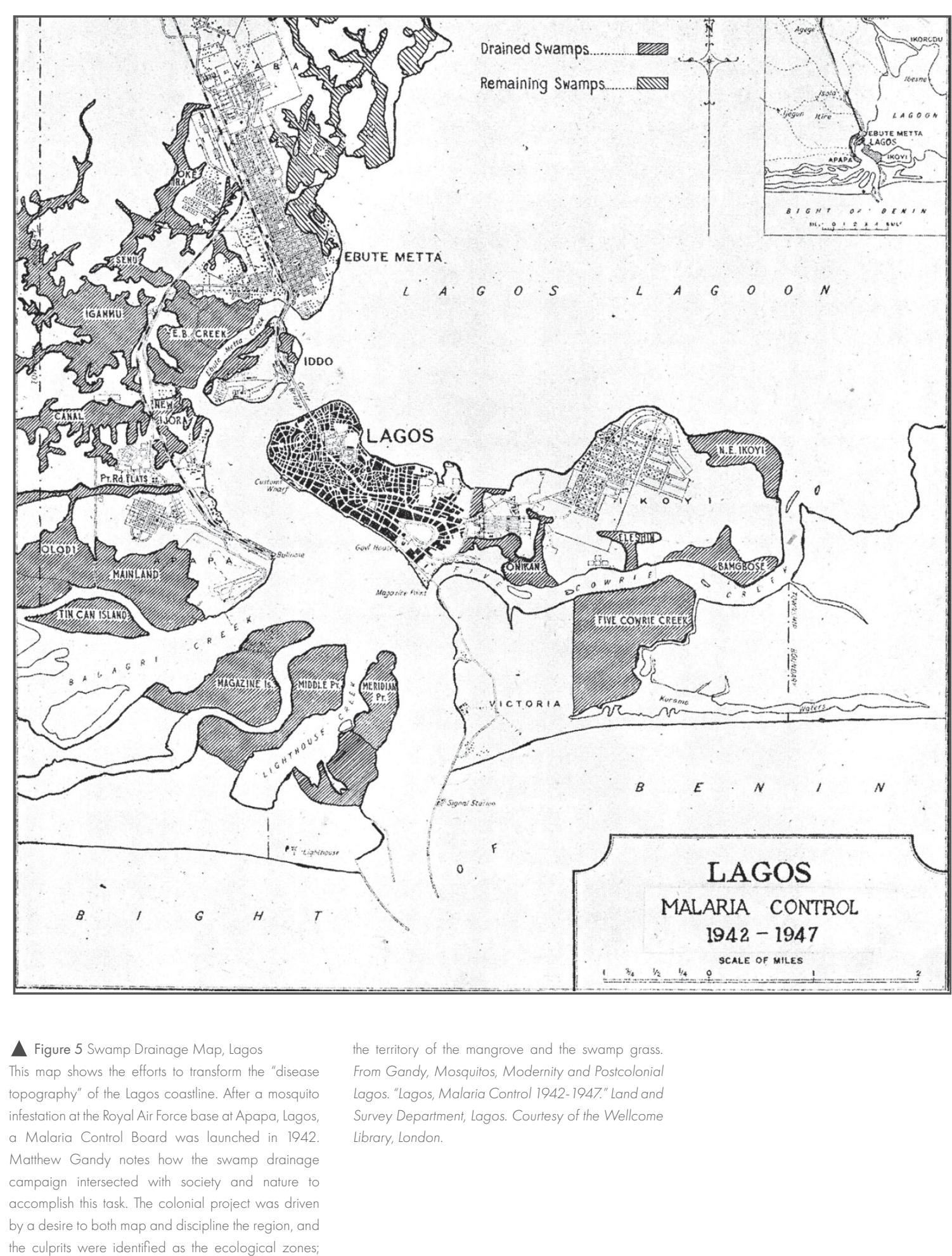
the 20th century can only rouse the curiosity; What alternative and ecological imaginations might have prevailed if the U.S Army Corps of Engineers did not assume so much control over the American Hydraulic Landscape?21

\section{Using Maps to Understand the History of the Lagos Landscape}

The strategy of using maps to understand how the landscape of Lagos changed over time presented many complex problems. The map is a political tool, a reflection of a cartographer's ideologies materialized into territories and boundaries. Access to indigenous knowledge of the landscape would likely only have been available in the oral tradition. Further, in Fiffy Years of Post-Colonial Mapping in Nigeria, Nnabugwu Uluocha notes that much of Nigeria is presently under mapped due to economic and political instability, lack of funding, and unreliable current information. Uluocha notes that in addition to other private entities".. corporate organizations have had an impact on the post-colonial effor to map Nigeria, particularly the oil-industry giant Shell Petroleum, which has made impressive contributions to the geological mapping of several parts of southern Nigeria. Other oil companies such as Chevron, ExxonMobil, and Agip have also contributed to the 50 years of post-colonial mapping of Nigeria". 22 Keeping this in mind, the maps would provide an important starting to point to begin to understand retrospectively what foreign interests projected for the future of Lagos by understanding their omissions, inclusions, and visions.

The maps that were created of Lagos provide an account of how the ecology of Lagos was transformed (specifically wetlands an vegetation) through the operations of dredging, draining and railway construction to enable industry (mostly petroleum). In Lagos: A Cultural History, Kaye Whiteman gives an account of Lagos that is focussed on industry and using engineering to win the war against the lagoon, “ “... the greedy, muddy-coloured sea absorbing like some insatiable monster the masses of grey rock hurled, at all times of the day and every day in the week..." ${ }^{23}$ Contrastingly, in The Fabric of Space, Matthew Gandy gives an account of Lagos in which concerns of health and sanitation led to interventions on the land. Figures 14 and 15 show maps of Lagos in 1962, where Apapa which was previously a predominantly marshy land, has been filled and transformed into the Port of Lagos.

In Gandy's Mosquitos, Modernity and Postcolonial Lagos, he describes several attempts to transform what was considered "...the "disease topography" of the Lagos coastline, ${ }^{24}$ to satisfy British attempts to transform Lagos into the 'Liverpool of West Africa'. ${ }^{25}$ Lagos, which was characterized by swamps, marshy land and mangroves, had a landscape that was believed to play a role in the transmission of Malaria. There were early attempts to address these concerns but after the infestation of the Royal Air Force base at Apapa in the 1940s, a more serious campaign began from 1942-1947 which involved the embarkment of an extensive swamp drainage program. Figure 5 shows the effect on the landscape from the swamp drainage campaign, yet later maps of Lagos either indicate that some areas were re-swampified or that the campaign was not carried out to its full extent.

Describing the topography of Lagos, in Lagos: A Cultural History, Whiteman gives several accounts of different authors who described the 
perils and dangers of the entrance to the Lagos Port; as a place that was dangerous, unpredictable, and unapproachable, the lagoon often carrying with it the force of the Atlantic. He notes that "...access to the deep-water anchorage that lies between what is now Lagos Island and Apapa was rendered perilous by the "bar," a sandbank across the entry to the lagoon from the Atlantic Ocean that made all navigation perilous, especially for larger ships. ${ }^{26}$ The transformation of Lagos into a port city came with the construction of two breakwaters known as the East and West Mole beginning in 1905 and completed in 1912. This allowed ships to freely enter the Port of Lagos and discharge cargo directly and "... once the problem was cracked in the early twentieth century, it unlocked the port city's huge economic potential". ${ }^{27}$ The location of what was once the perilous bar is now the site of Bar Beach and the home of the new city on the Atlantic which has been advertised as sustainable and holding a commitment to green building initiatives: Eko Atlantic. Apapa is chosen as a site of scaled study because of its industrial and military history, and its historical importance as the Lagos Port Complex.

\section{Sections, Model-Making and Illustration}

The questions that arose after the mapping exercise were how do we begin to move away from mapping which provides a limited understanding of space? How can this information help to imagine the city differently? Sections, Model Making and Illustrations would provide another reading of space that would bring about a variety of conclusions in which to speculate on the future. For example, in Soak, Anuradha Mathur and Dilip Da Cunha imagine Mumbai as an estuary. What if

Lagos remained a city of mangroves? A city that was drawn with an interest of ecological concern rather than the realization of profit on an international stage (British Interest)? With these considerations in mind, how can architecture work with ecology to imagine the city differently? Models are created, predicated on the idea that different technologies (high or lo-tech) ${ }^{28}$ can bring about different environmental processes. These models form the basis to imagine speculative infrastructural devices that might work with ecology to create architectural opportunities for habitation.

The Glossary

The glossary highlights the importance of language in constructing narratives and methodology in constructing space. Two glossaries highlight two ways of conceptualizing and thinking about the environment. The Old Glossary (xiv-xv) highlights ways of conceiving the environment that commodify, extract, and see it as an entity subservient to human endeavours and ways of living. Contrastingly, the New Glossary (xvixvii) highlights ways of working with the environment and suggests practices and ways of living rooted in the social production of space, guided by both human and non-human actors.

Twitter for Geoverse

"This is the lesson: Great cities are like any other living things, being born and maturing and wearying and dying in their turn." - N.K Jemisin, The City We Became

In the article Should Trees Have Standing? - Towards Legal Rights for Natural Objects, Christopher D. Stone makes the case for granting elements 
in nature certain rights under the law. He argues that "Throughout legal history, each successive extension of rights to some new entity has been, theretofore, a bit unthinkable. ${ }^{, 29}$ Further, if we can afford rights to trusts, corporations, municipalities and even ships then it means that non-human things can also come to be recognized as possessors of rights. Granting rights to the natural environment will not be “....as silly as that no one should be allowed to cut down a tree, ${ }^{, 30}$ but will guarantee entities guardianship and legal protection by protecting them against exploitation, ecological damage, and risk of endangerment. Stone argues that if neither corporations nor municipalities can speak but are still spoken on behalf of, this is possible, and the natural entity will be treated as a legal incompetent.

The idea of Twitter for Geoverse emerged from the sensibilities of environmental personhood and the idea of the sentient city in The City We Became, a city that lives, dies and breathes, personified by human avatars who represent different boroughs of the city. Twitter is a platform which has great value in contemporary culture because it affords people the ability to express their opinions in 280 characters (previously 140) or less. In some cases, censorship of twitter posts, such as in the case of elections is strongly contested and considered an attack against free speech. Using this medium, a fictionalized version of the app located in a "Geoverse" or a geographical universe affords elements in the environement a voice in which concerns might be represented in a language that is understood and culturally relevant. The idea of Twitter for Geoverse is not to anthropomorphize the environment and its associated qualities but to give a presence and a voice to an entity that sometimes seems elusive or beyond us. It is a medium for storytelling and a tool that is used throughout the project to narrate in a way that is direct and concise. Retrospectively, the device is used to tell the story of land involving breakwaters, islands, and the movement of the lagoon. In the present, twitter is used to tell the story from the human perspective which centers around environmental problems-flooding, coastal erosion, extreme rainfall, and to establish hypotheses for their causes. In the future, it is used as a tool to narrate and predict along the trajectory of the past and present

Collage

Collage is used as a device to combine different ideas of a place into a single visual narrative. It is used to illustrate certain feelings and ideas of place. For example, Figure 4, Dredge Drill Drain, compresses the narrative of several maps into a single drawing, telling the story of industrialization, urbanization and the emergence of a city. In the future, it is used as tool to move the narrative forward.

Worldbuilding and Speculative Fiction

Narrative writing and fiction are used as important catalysts for the investigation of the past, the understanding of present issues and the speculation of a future site existing between now and the year 2100 . The methodology provides a framework to understand the correlation between how specific ways of operating on the land can result in different landscapes and possibilities of habitation that may or may not be inclusive or problematic(environmentally). For example, the idea of land reclamation often goes with the terms developer, urbanization, and in many cases 
the commodification of the ocean for private profit. Contrastingly, ideas of stewardship and remediation typically connect with ideas of ecology and sustainability. Within this historical framework of understanding, a subversion then becomes possible through re-mapping, re-imagining and rebuilding the site in the process of speculating what might be sustainable and community-driven mode of habitation at the scale of the neighbourhood, that is self-organized and embraces the ecological qualities of what it means to occupy Lagos within its littoral zones. The environment and its associated processes are foregrounded to reflect the necessity of seeing them as a partner in approaching design in a way that heals, repairs and is rooted in an ethics of care. 
the other side of the Lagos lagoon are in the growing town of Apapa, which boasts a rail terminal

Situated two miles from the Atlantic and having an artiflcial breakwater running into the sea, Lagos is more vulnerable to possible enemy action than is Vichy-controlled Dakar Lagos lfes below sea level, and if it were flooded by the Atlantic only one tiny spot in the whole city would remain above water. This spot is the very place where the British blueJackets landed in 1851. On the other

hand, Dakar is sheltered by the seemingly unbroken mountain ranges which rises and falls intermittently, stretching from the British colony of Slerra Leone to French Senegambla.

- - - n - -




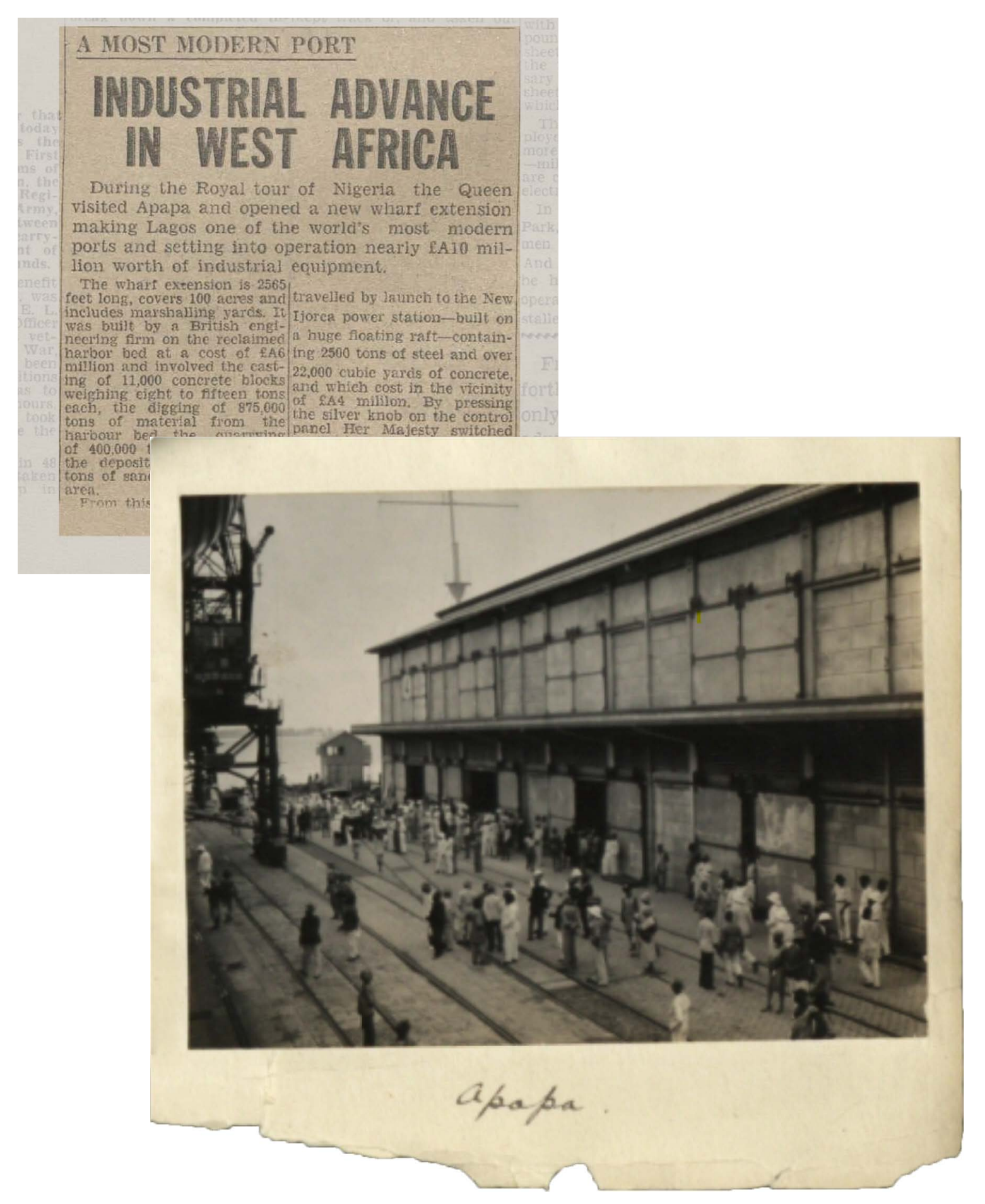


The goal of the mapping exercises was to pair an understanding of land and sea with particular ways of drawing, mapping and representing the city. Four maps are selected at different years, half of which are produced by foreign entities, and the other half by Federal Surveys Nigeria and other mapping corporations. These maps which range from the 1800 s to shortly after Nigeria gained independence (1960). The last is a generic map produced by Open Street Map in 2020. A parallel reading of maps allows for an analysis of two styles of representation. Maps on the left are mostly notational, while maps on the right represent a new way of re-interpreting, re-drawing and representing the city in terms of water (an element integral to its history).

\section{The Gradient}

In trying to break down the previous logic of mapping the coastal city, a gradient is created, which instead of using the map as merely a tool for demarcation and identification, tries to understand the nature of different qualities of ground. Each portion of the gradient is labelled as a thing with a certain capacity to hold water ranging from concrete which has none when fully cured, to different kinds of wetlands, finally ending at water. This gradient recognizes the fact that Lagos is a city of islands and sandbars, and that its character and soul lies in its relationship to water. It is water- in a certain capacity 
grades of colonial ground

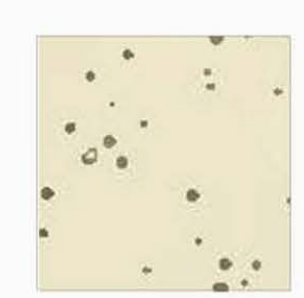

sand

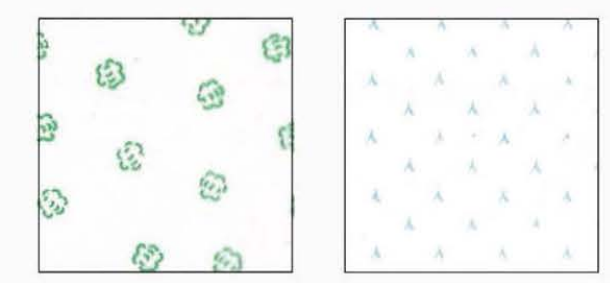

bush

mangrove

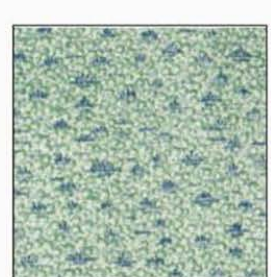

mangrove

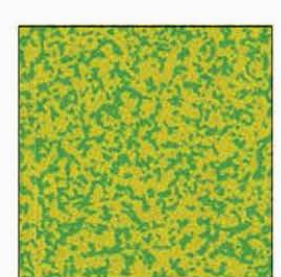

wood/swamp

marsh
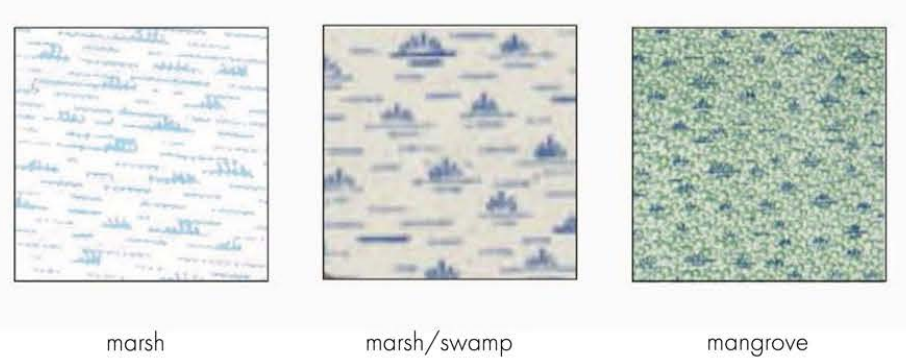

marsh/swamp

mangrove

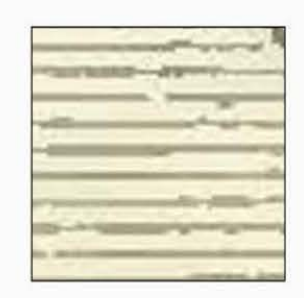

water

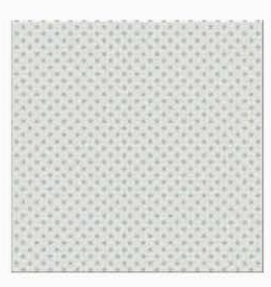

marsh

holding tanks for water

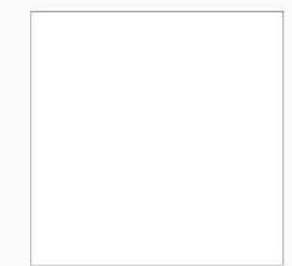

concrete

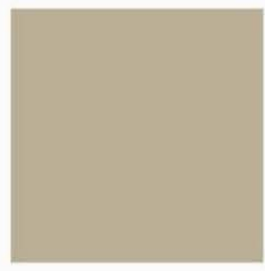

dirt/sand

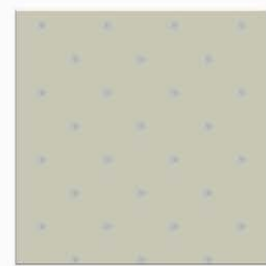

bush

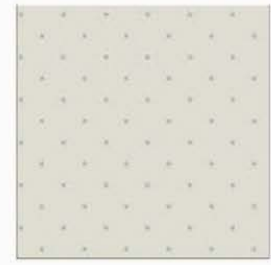

mangrove

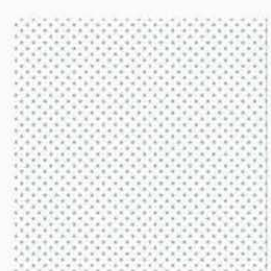

water

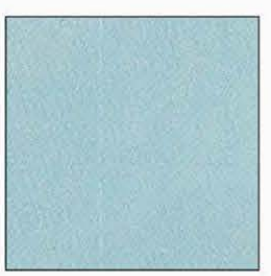

water

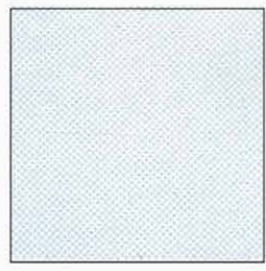

water

$\triangle$ Figure 9 Gideles of Colonial Ground Gradient

used in old maps of Lagos
Vigure 10 Holding Tank for Water Gradient 

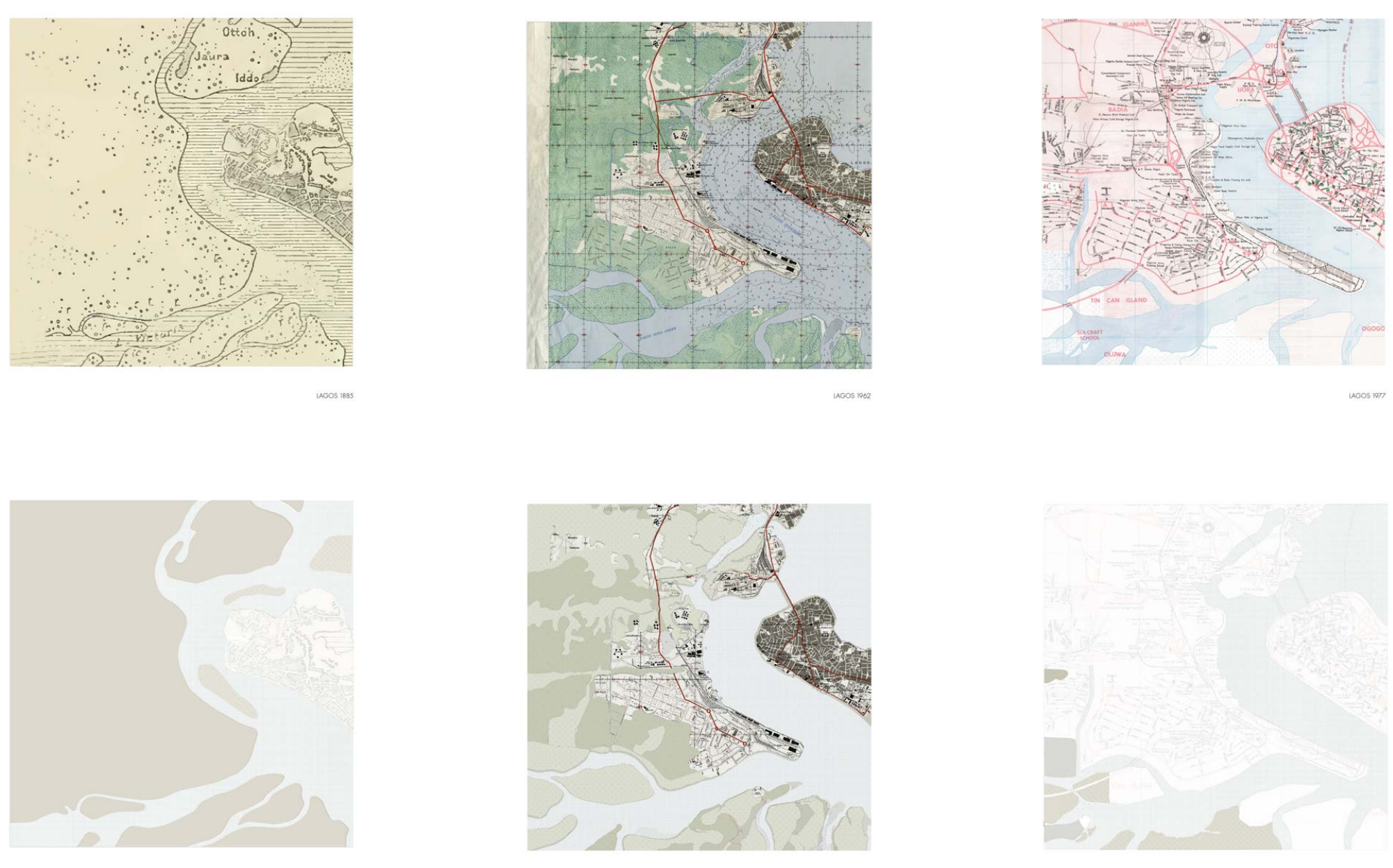
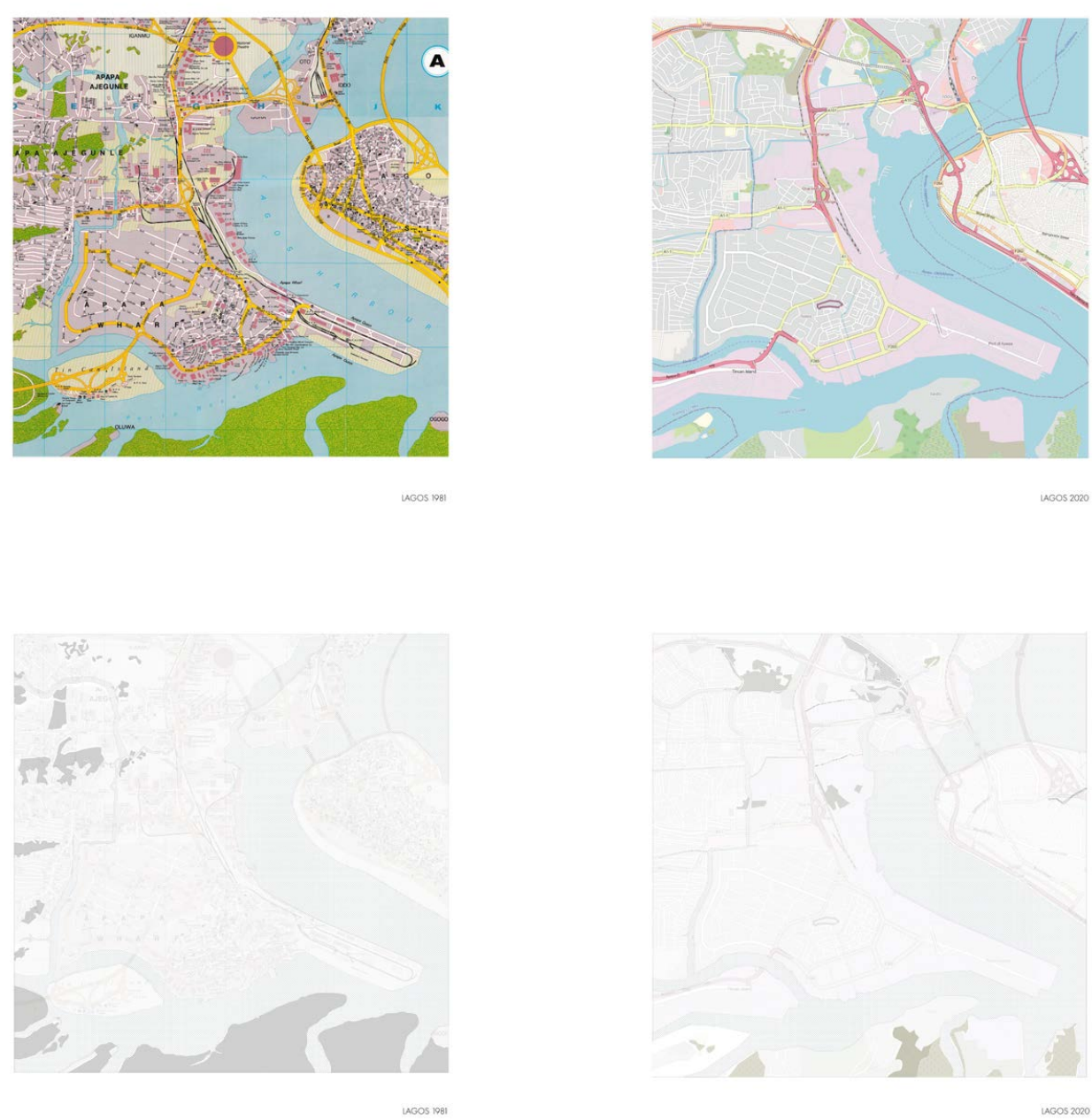


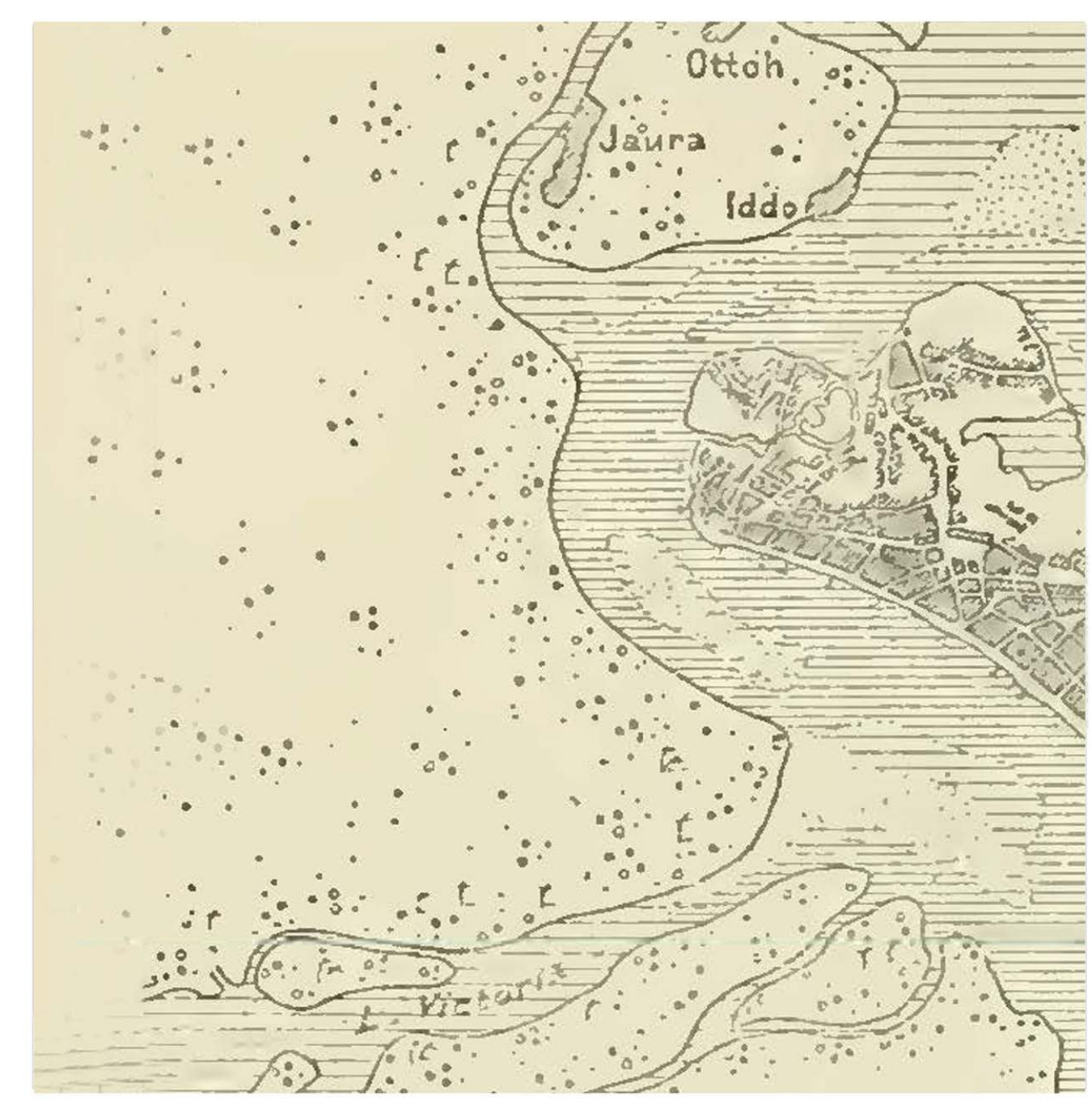

$\Delta$ Figure 12 lagos 1885

This is a 1: 900000 scaled map, taken from

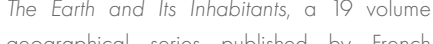
geographer Elisée Réclus. It describes Lagos cily are exposed at low water. This map is an

excepition to the series of other maps that follow

because 1 tocusses on the relationship of land-

qualities of the city. The spoce is rendered as

mythology of an enticing territory ideal for

gy of on enicing territiory, ideal
st (Reclus, 270).

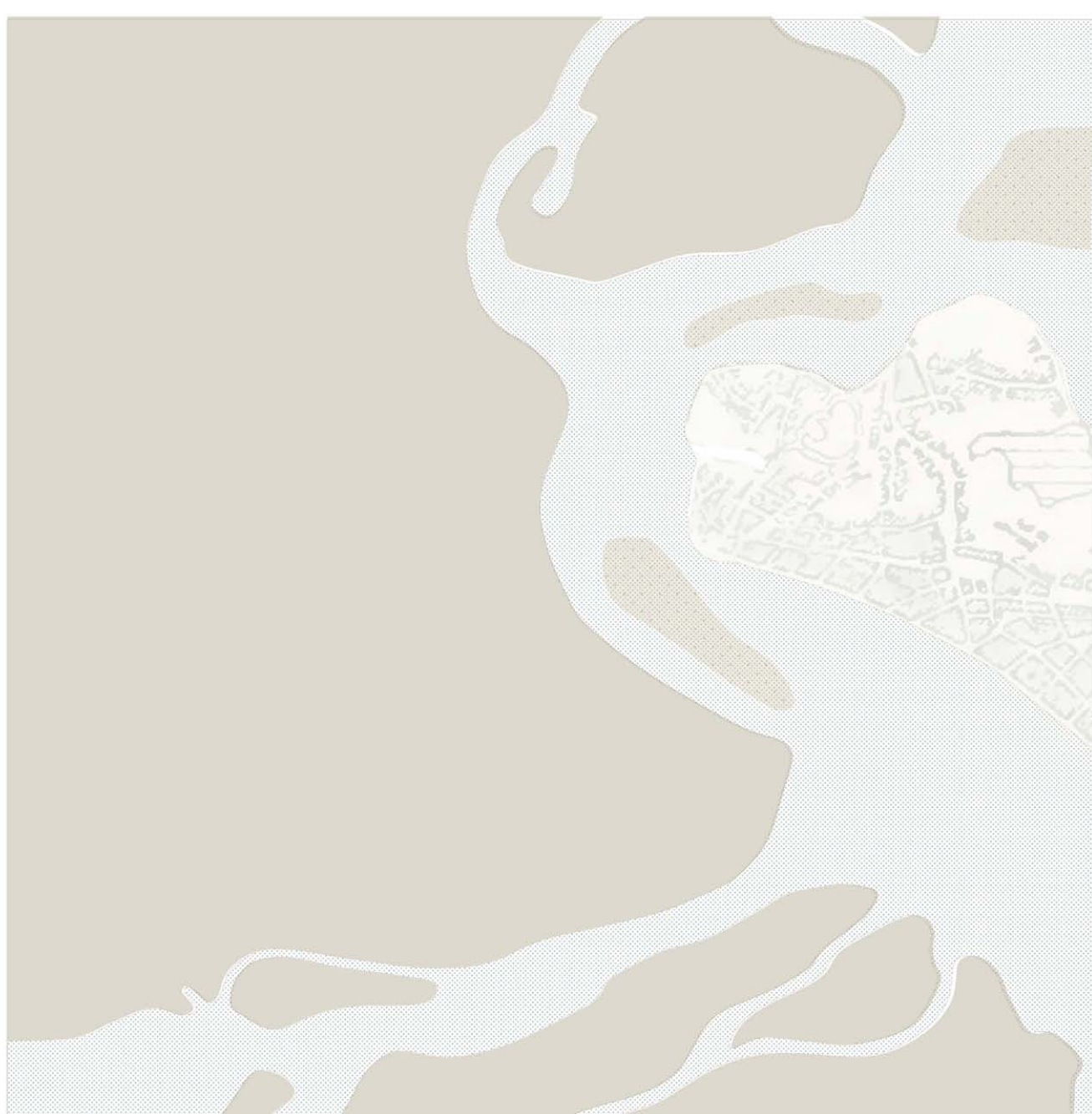

LAGOS 1885 


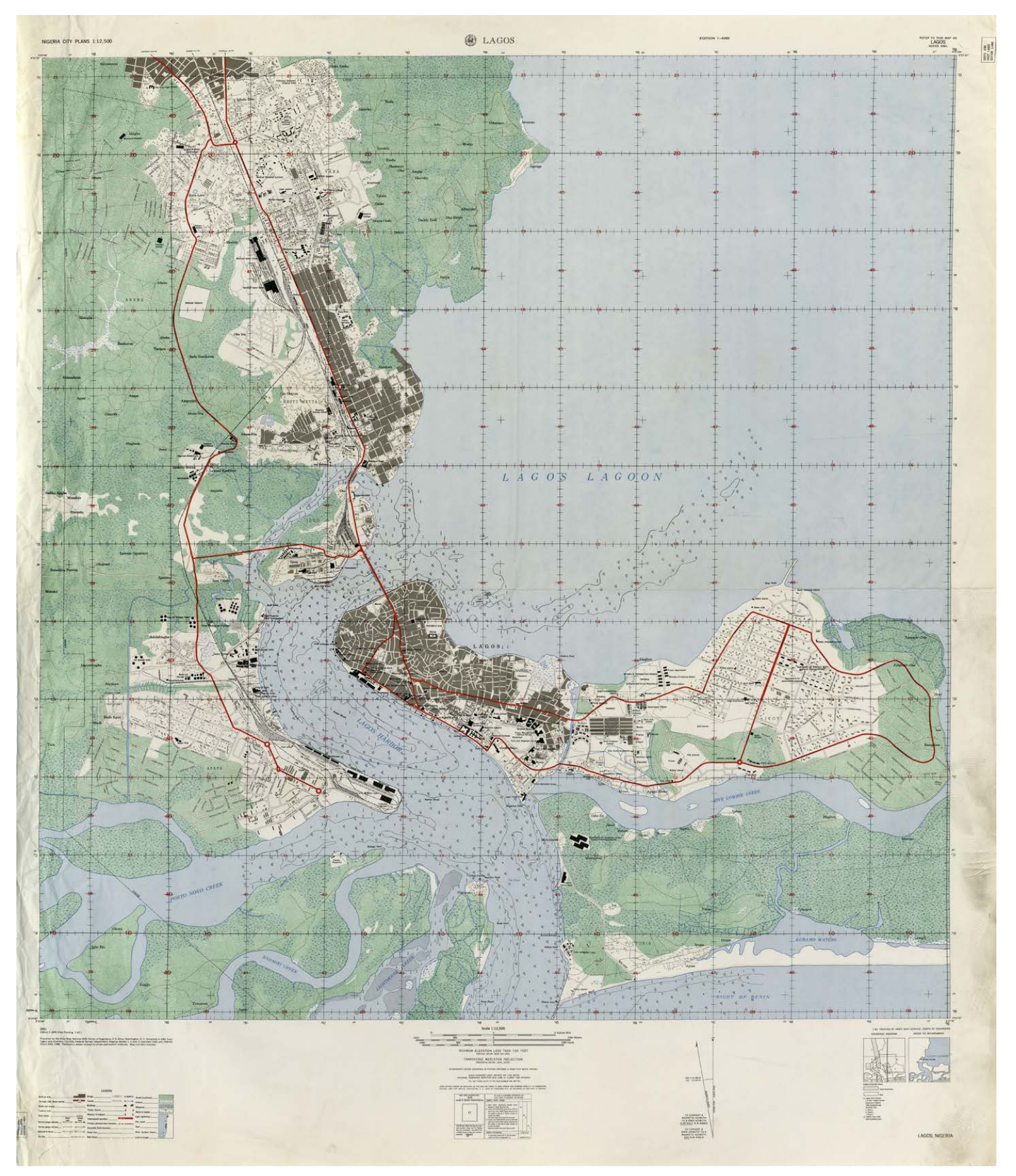

A Figure 14 Lagos 1962, US. Amrmy Corps Map

Prepared by the Army Map Service (AM), Corps of
Engineers, U.S Amy, Wastington D.C/ Compiled

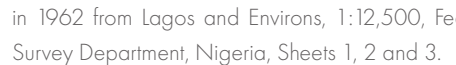

- Figure 15 Logos 1962

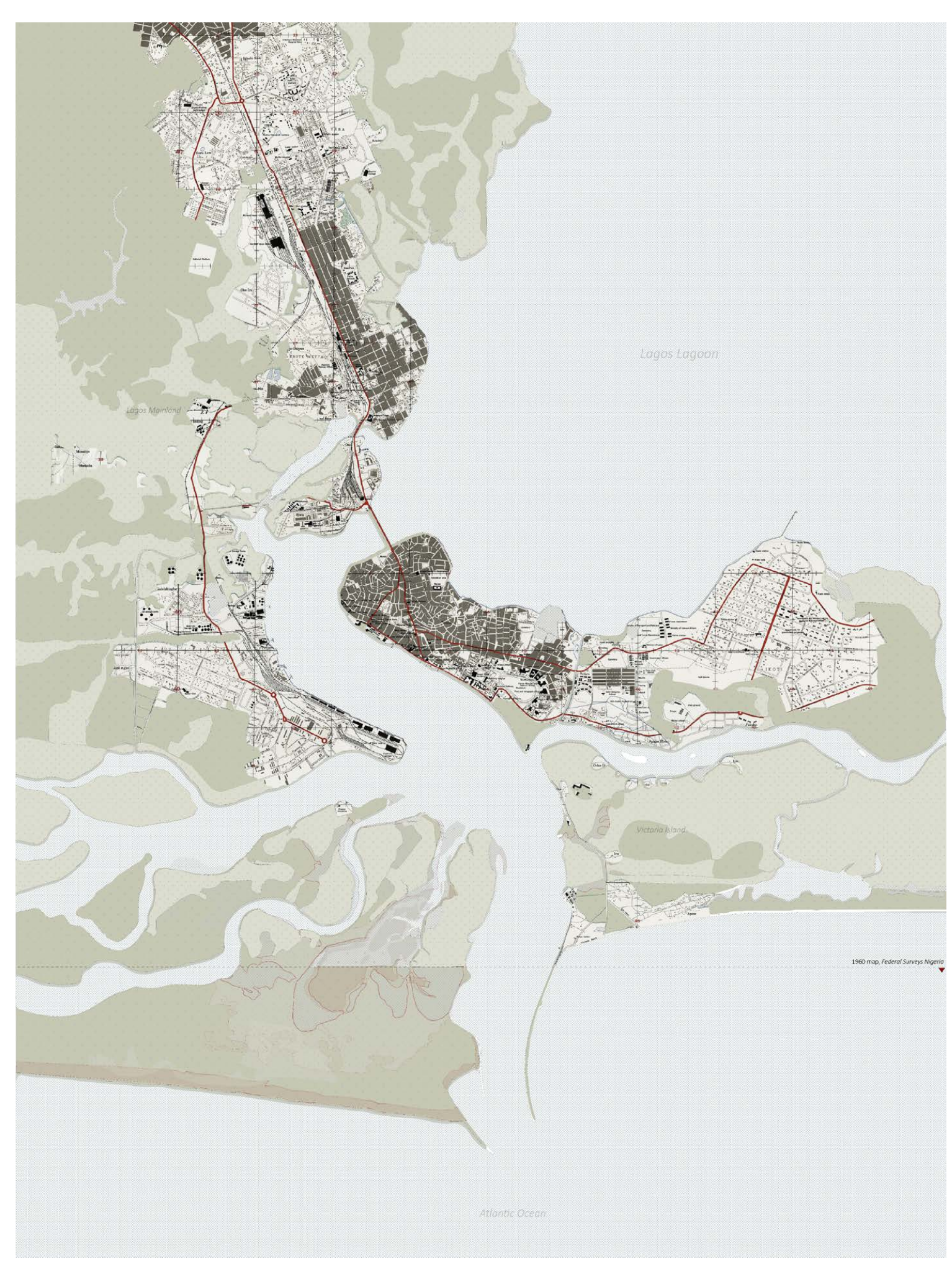



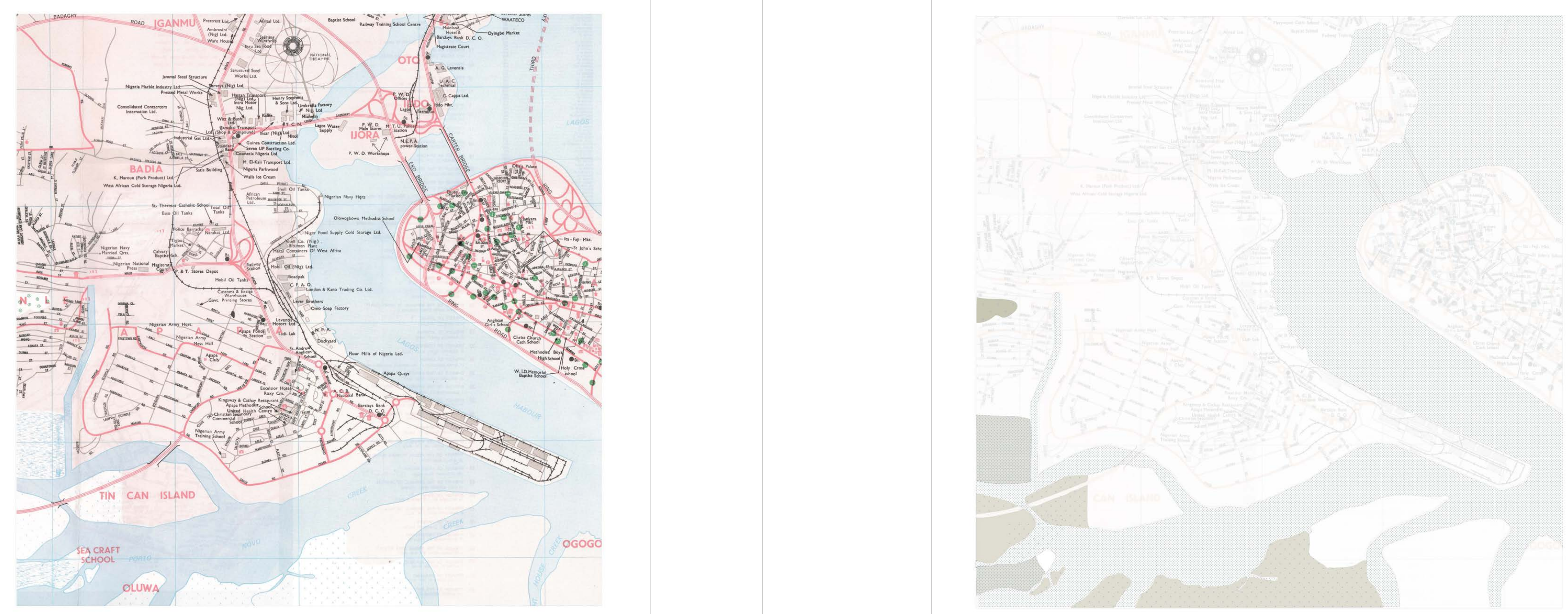

LAGOS 1977

$\operatorname{14c05} 1977$

A Figure 16 logos 1977

"TeNatin's Capital, a Street Guide to lagos." Lagos

Federal Surveys 1977 , Pinit:While new elements migh
hove been added to the postindependence mat

(1960+1), the methodology of the maps still remaii
colonial in nature and are indisinguishable save for the

indication of a local author. 

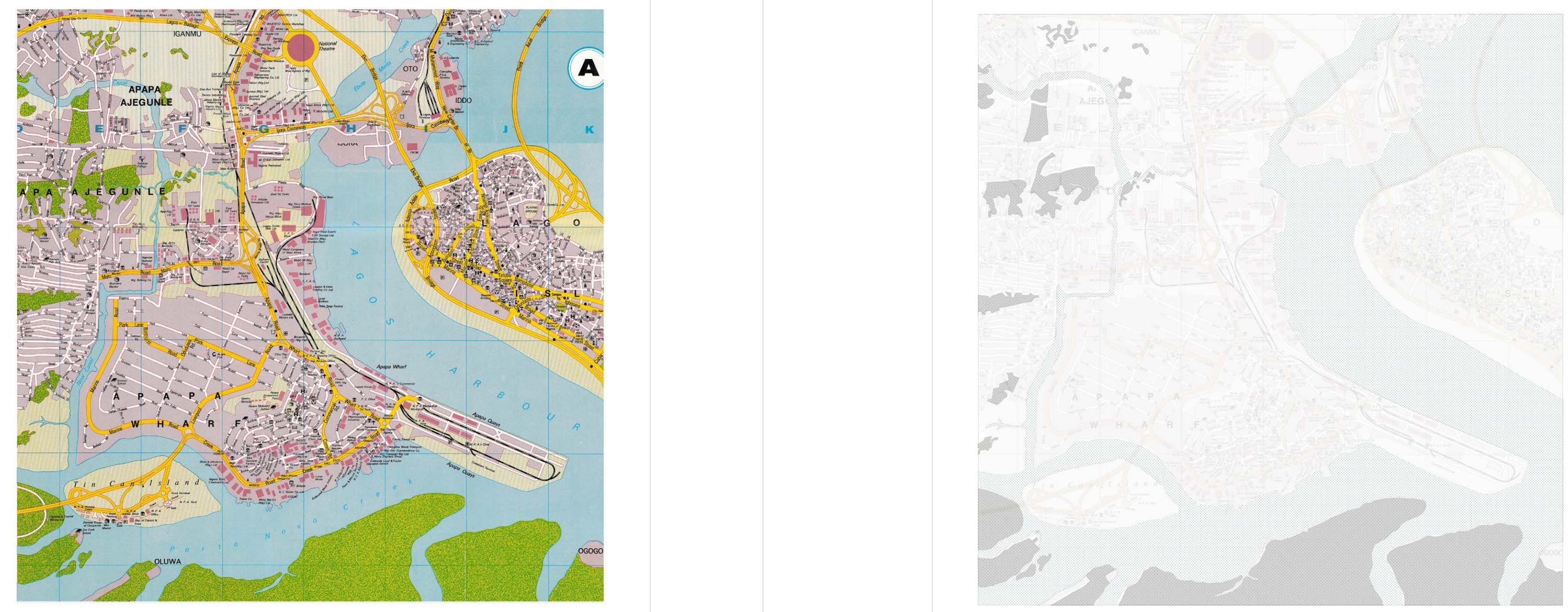


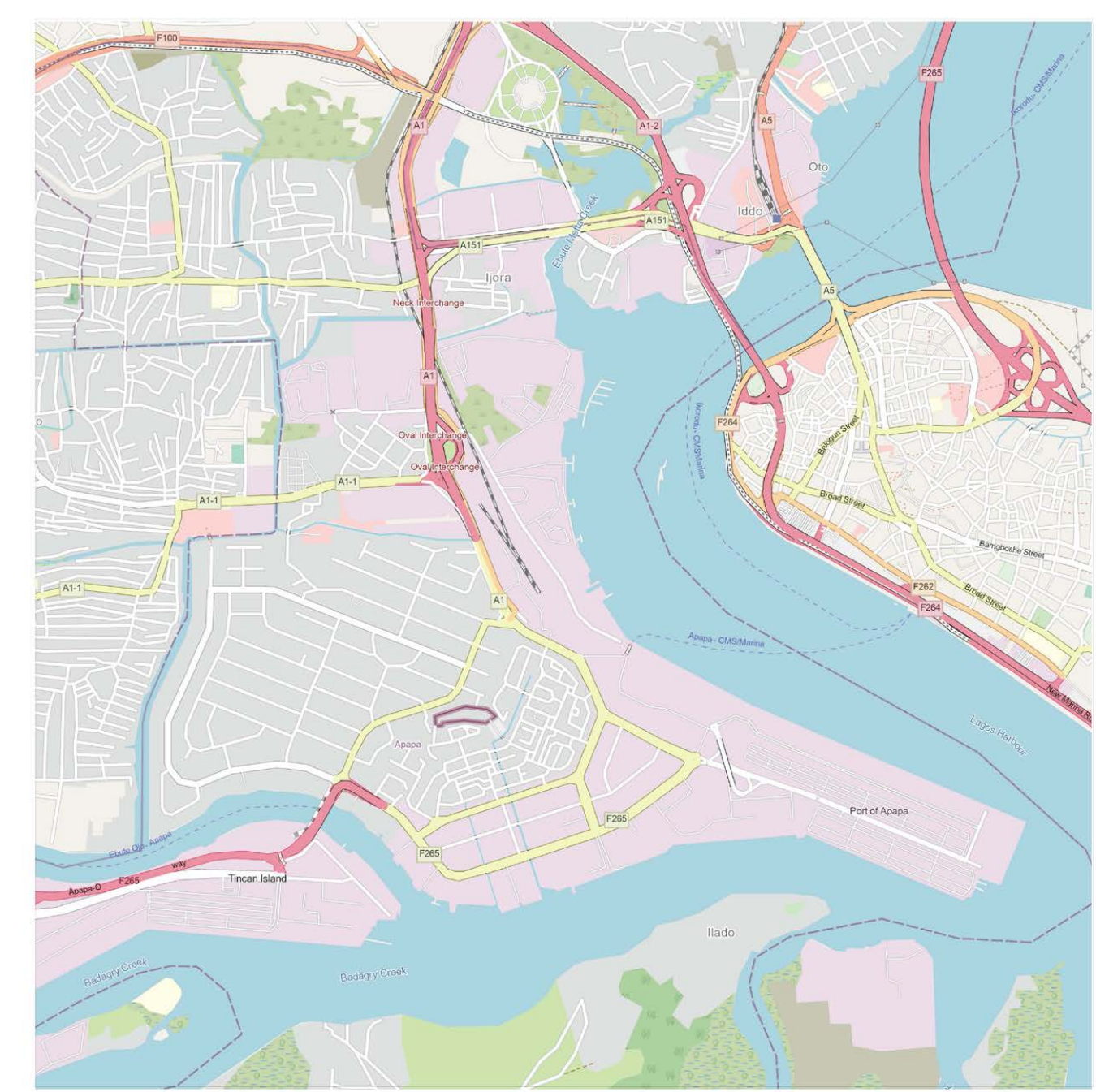

LAGOS 2020

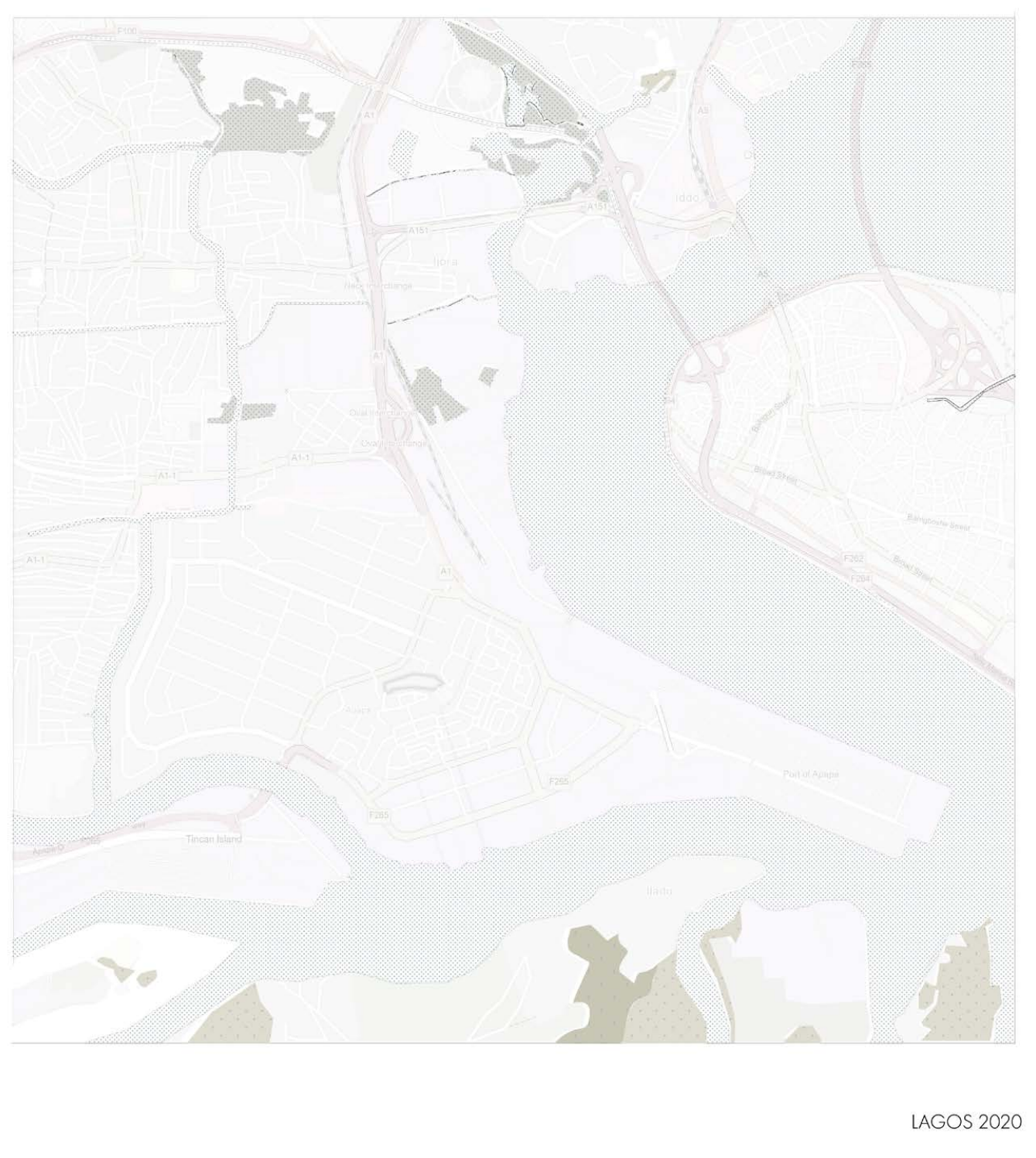




\section{Hard and Soft Edges}

"Retbinking the question of nature here is a matter of finding the right questions rather than looking for immediate answers. It is about thinking and retbinking in berited ideologies and assumed truths through the creative use of representation as tool for thought in the production of architectural knowledge" (Agrest, 9 )

The idea that modes of representation have an epistemic value has been an important theme in my thesis explorations. Representation is intrinsically tied to modes of seeing and objectivity and the way the environment is represented is related to how we view, treat and inhabit it. The conceptual models that follow ask the question: How can a model be a tool for exploration and generate new ideas and information, rather than simply being a direct copy of what it aims to represent? No variation of dots and hatches can convey the complexity of what it means to set foot on a swamp or provide access to the intricacies of mangrove root systems which require insight into tactile and material qualities. The models were created in Dr. Lisa Moffit's Class Miniaturizing the Gigantic which used tank models to explore what it means to miniaturize (through architectural representation) the gigantic environmental domain affected by climate change. 


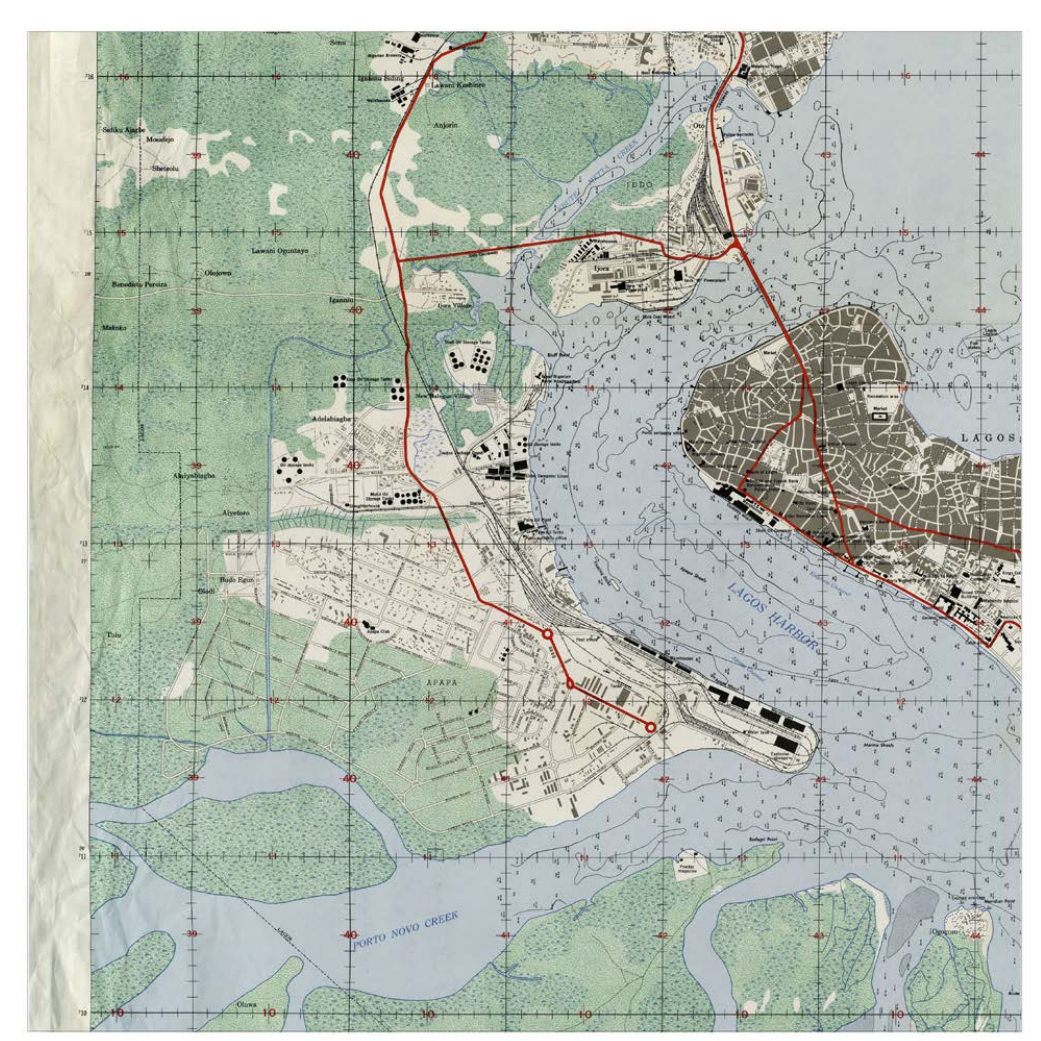

LAGOS 1962

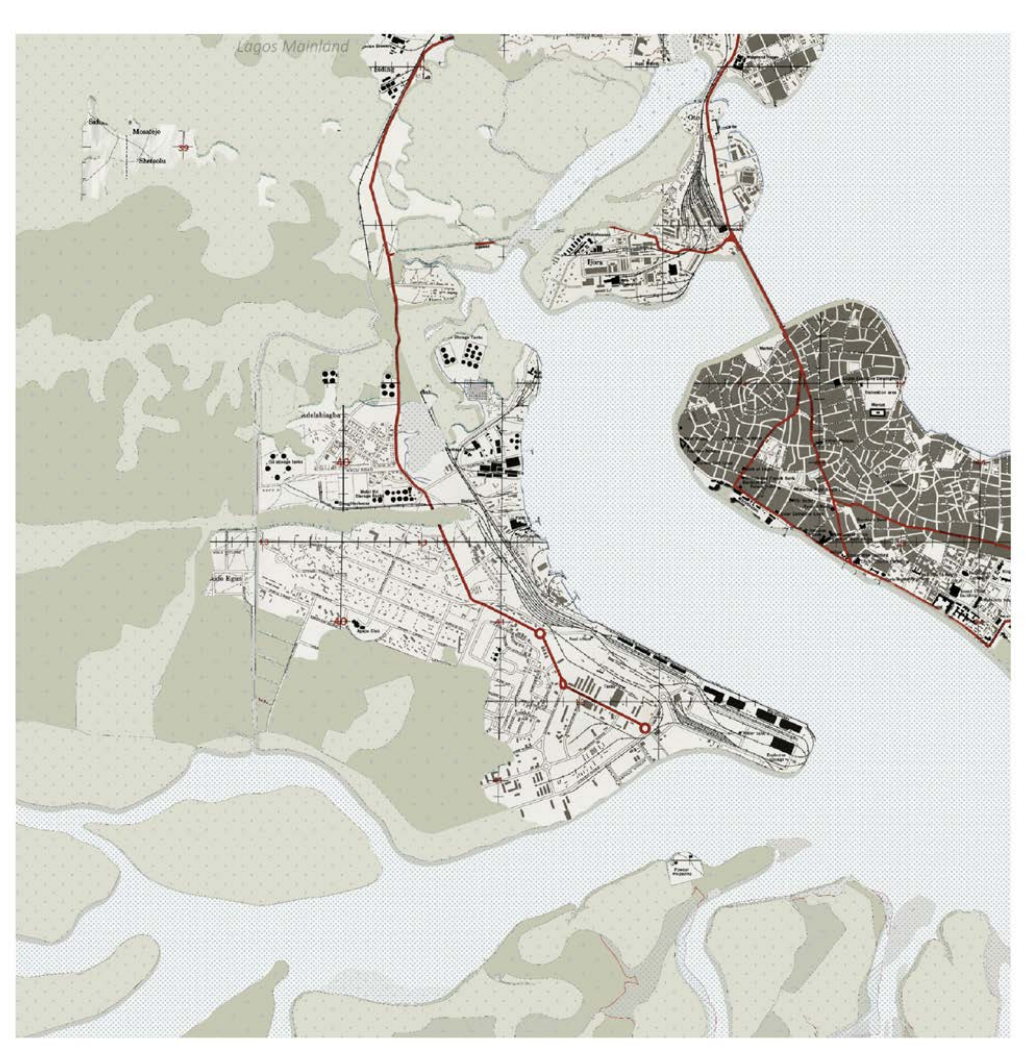

LAGOS 1962

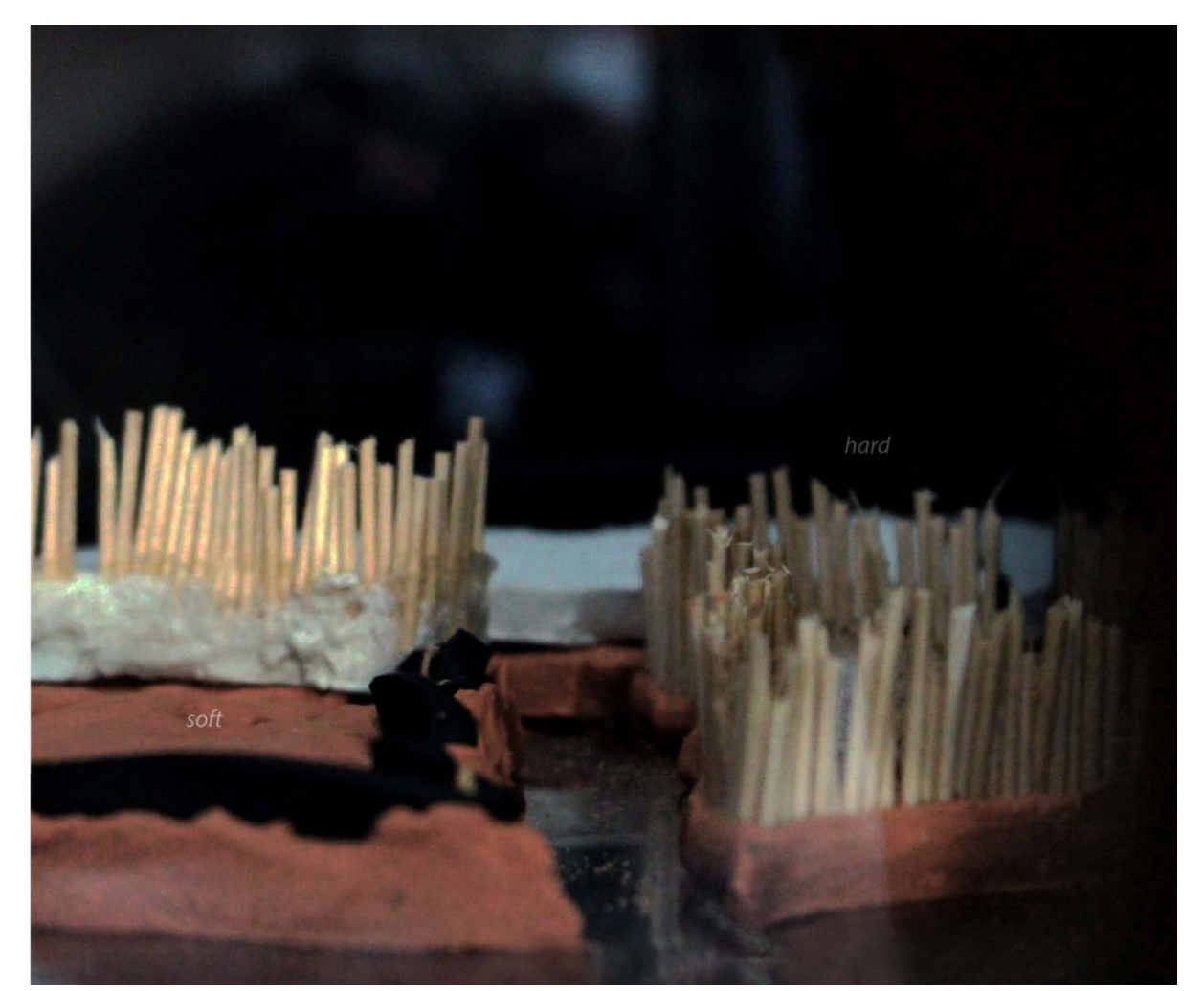

CONCEPTUAL MAP, 2020 


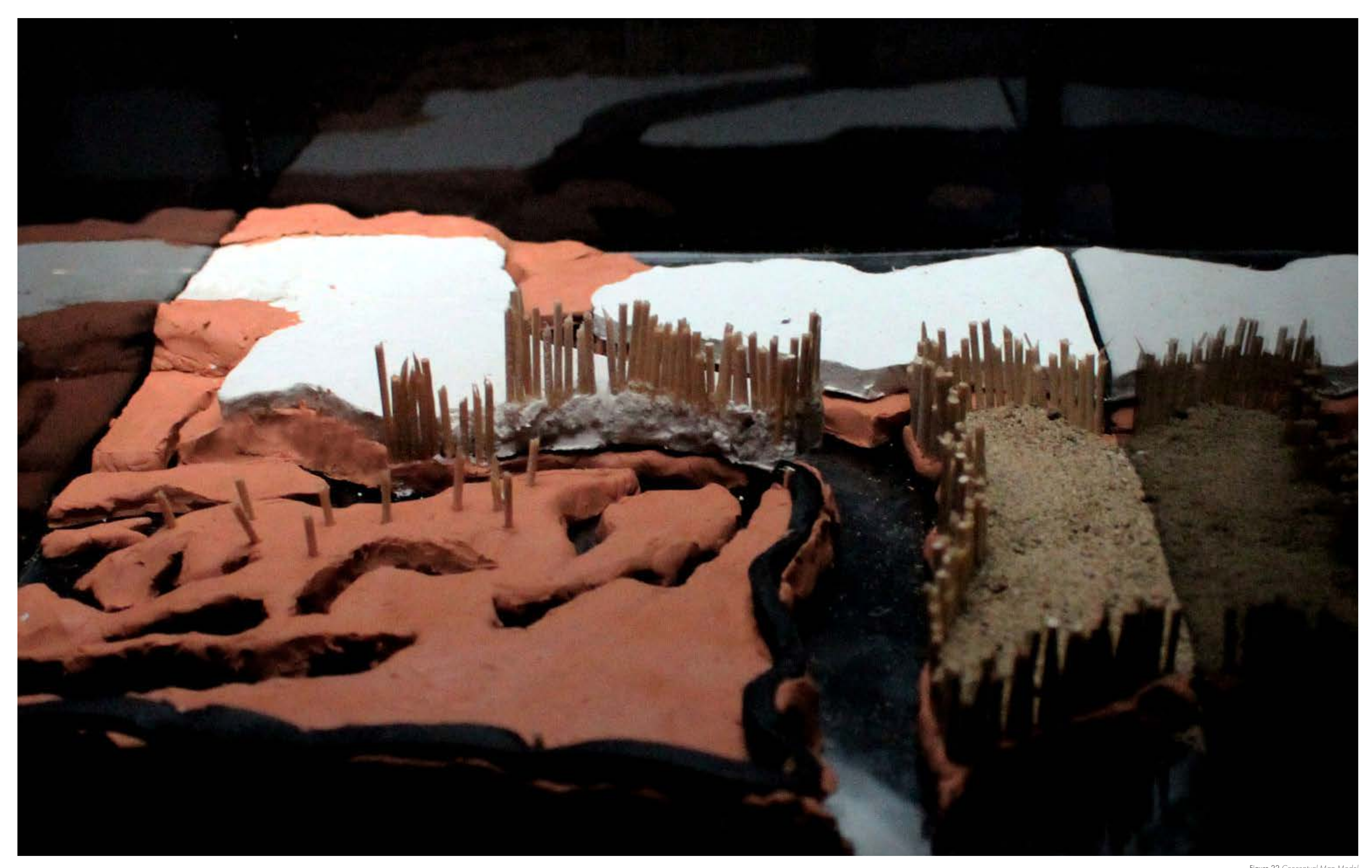




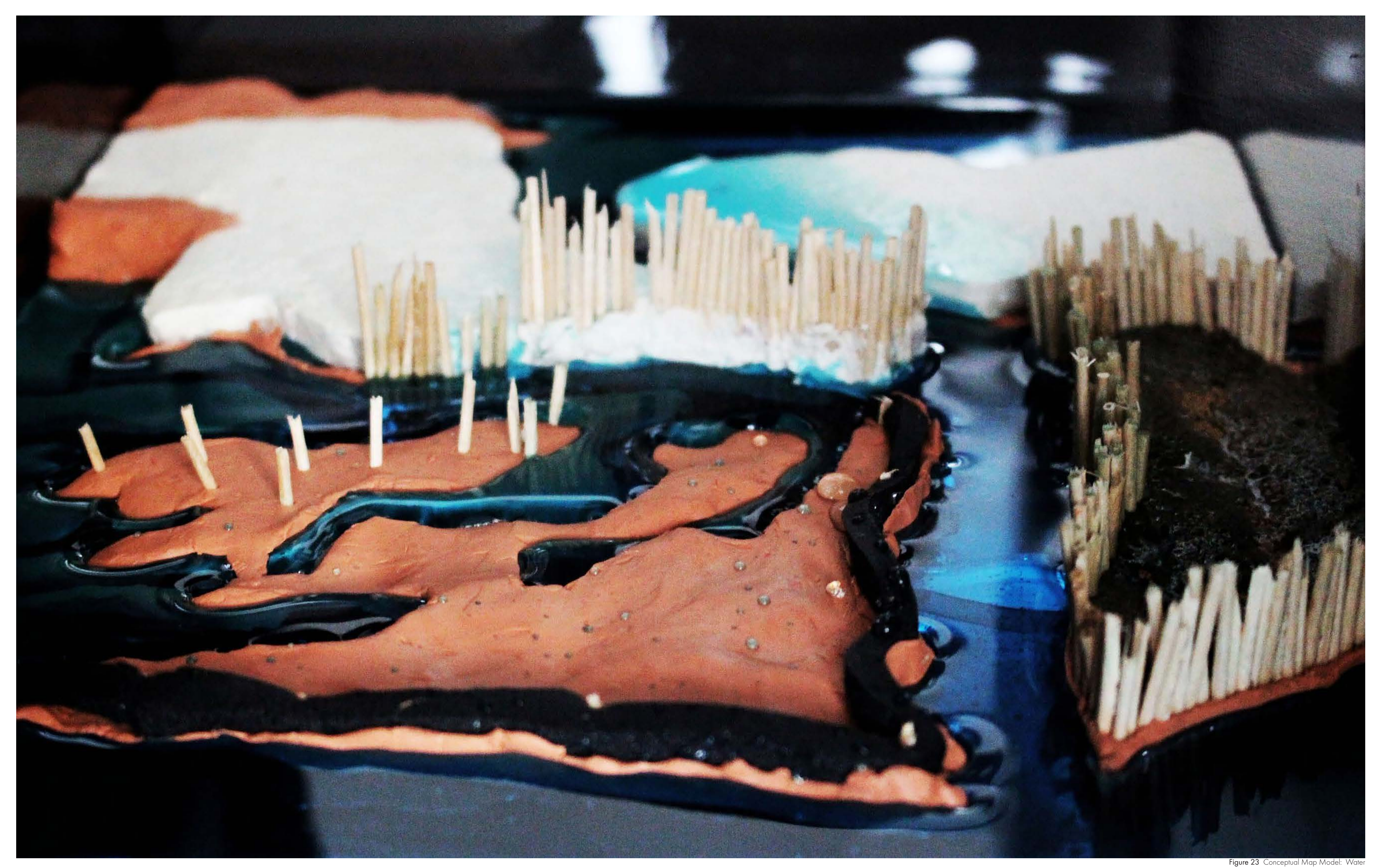




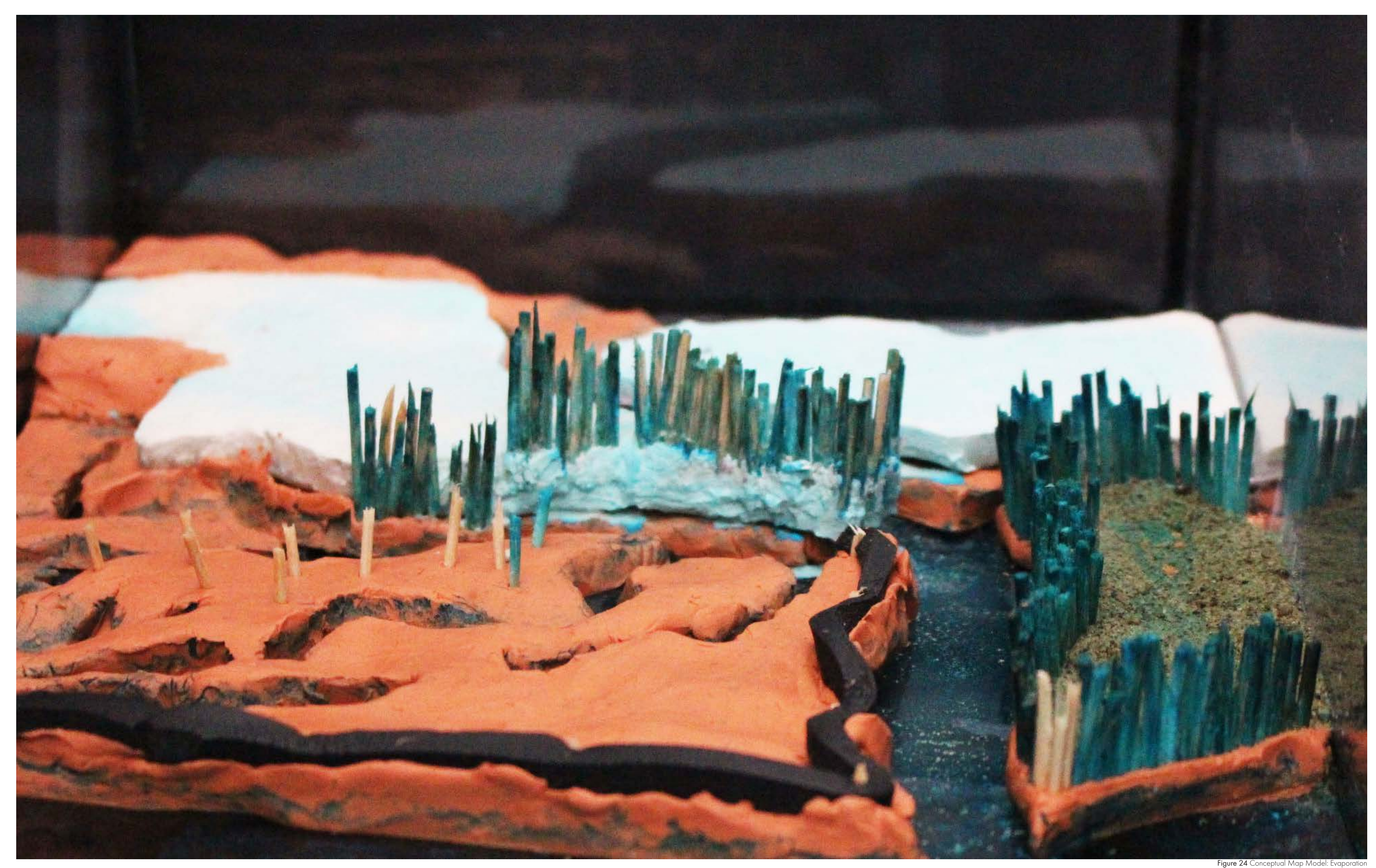



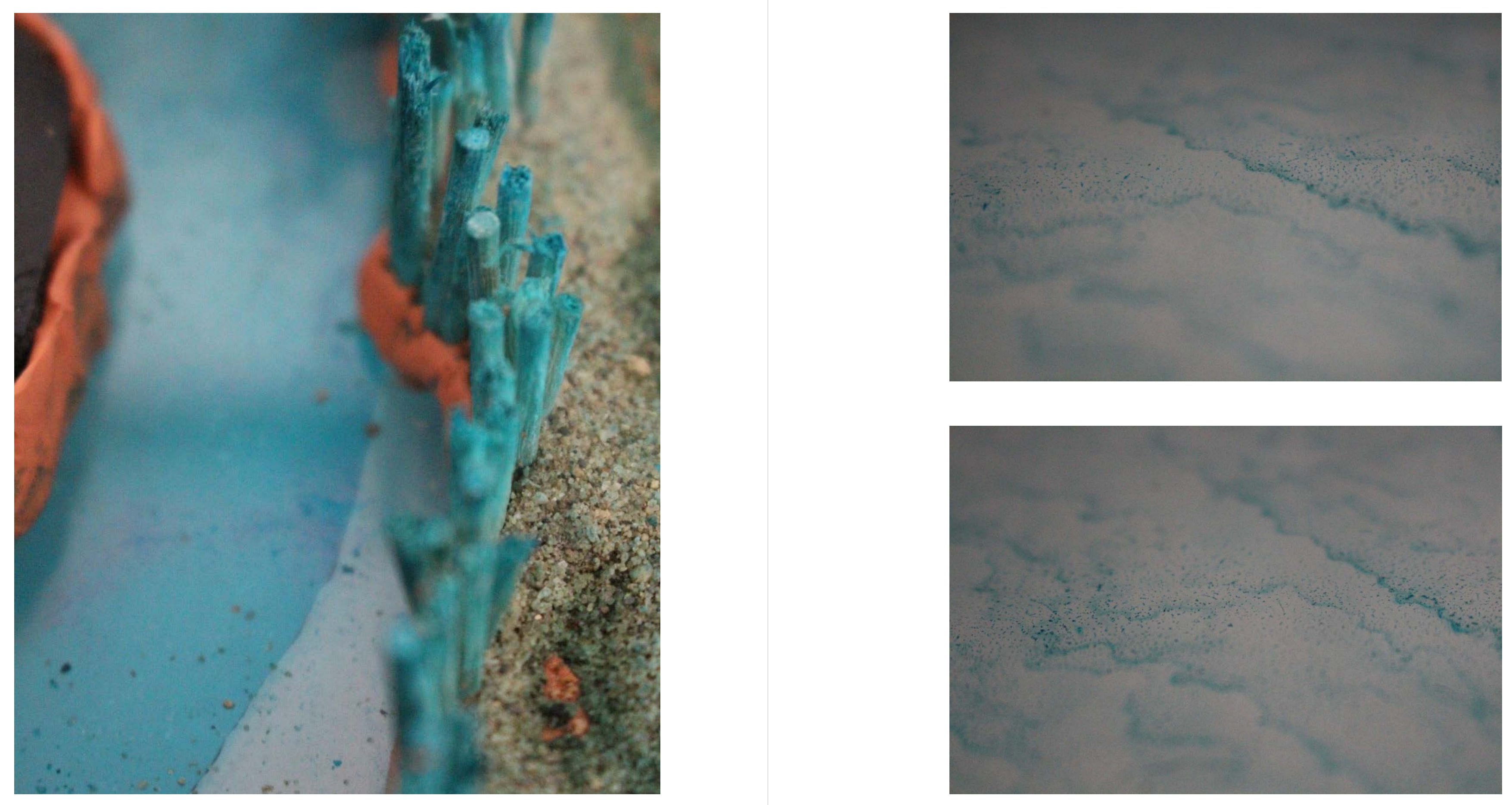

Figure 25 Conceptual Map Model: Aftermath

A (1) Material absorbency

- (2) Sediment and ink accumulated at base 
"The discipline of geography has failed to grasp the simple fact that the nature of accuracy and measure in Lagos is negotiable. Geography and the settlement of property in Lagos cannot be assessed and measured according to the fixed definitions of the census and the aerial photograph. Property lines are continually being reassessed and renegotiated in accordance with intersecting land laws, taxes, claims and interests."

-Koolhaas, Mutations (2001)

The idea of Time-Phased Sections was to offer a corollary to the mapping studies and interpret space in a way that would offer more than one reading. While maps are very one-dimensional—a single projection, ideology and vision, sections offer a more varied reading of what a map might present.

In some ways the sections that follow are speculative, insofar as they combine information from Google street and aerial views, while taking a few leaps of imagination to construct the type of space that might be "extruded" from a few lines and demarcations of boundaries. In other ways they retain some level of specificity; they belong to specific locations and places that may or may not sit on a map due to the fluid conditions of movement (that come with the urban condition), or other changing environmental conditions. Hence, these sections are not a 1:1 translation and should not be read as such but should be regarded simply as another reading of space. The images that follow construct a specific location on the map, with attention to the changing qualities of ground across the years. 


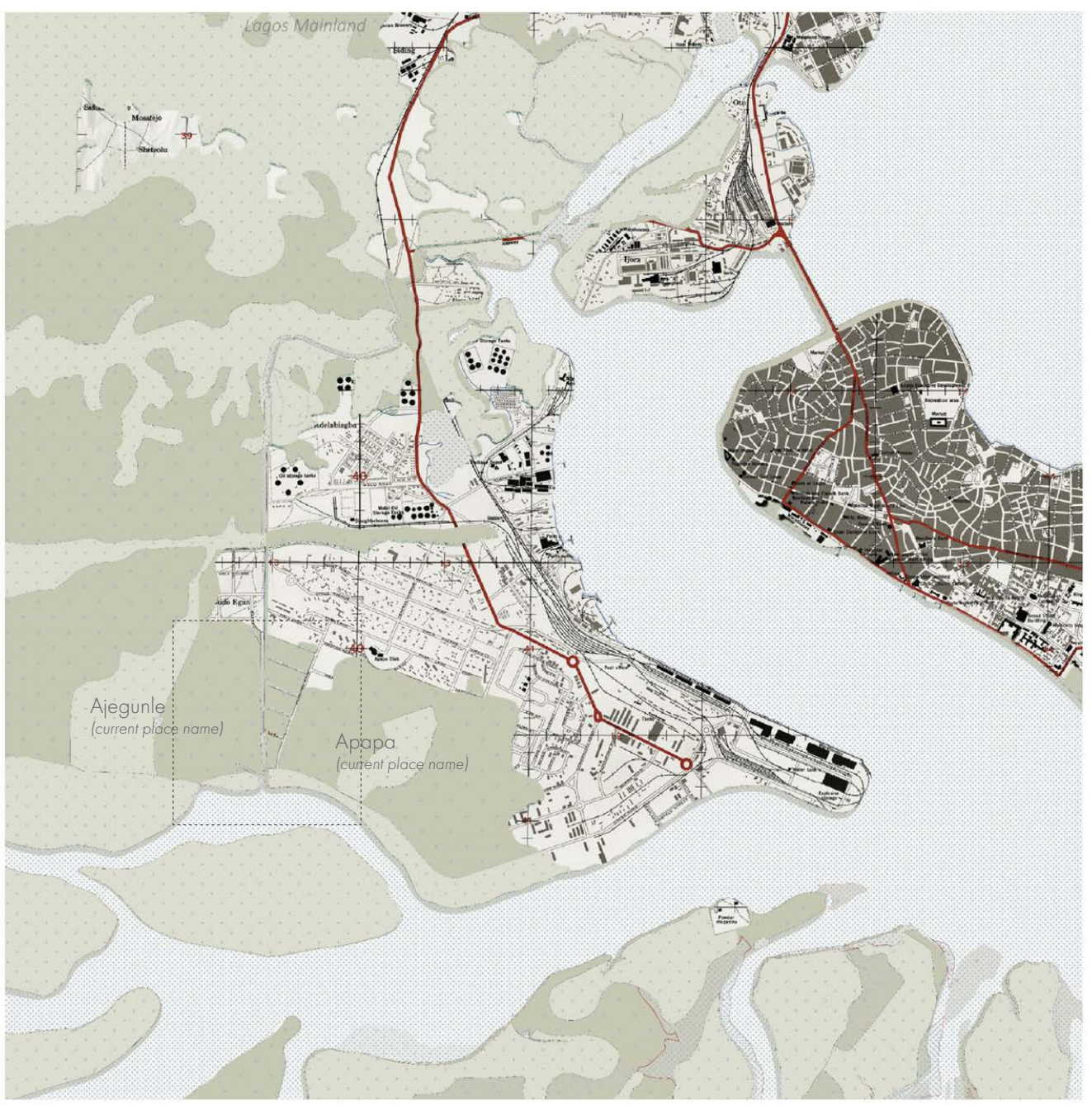

LAGOS 1962 


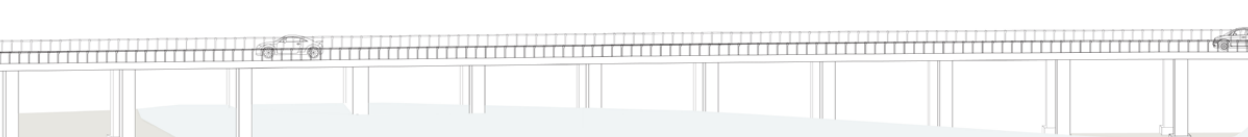

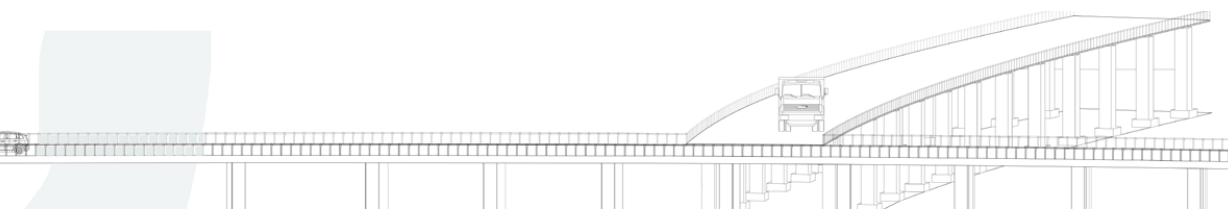

morio beact

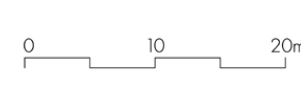

A Figure 28 Section 2- Canal, Apapa-Aiegunle 
METHODOLOGY III: EXCERCISES IN FORM-FINDING

The idea that the history of technology is in many ways a history of environmental modification, ${ }^{31}$ was the guiding principle for exercises in form finding. Embracing the idea that the landscape is by design, it imagined through different conceptual exercises, how the landscape might change, in scales ranging from the urban to the human through different programmed devices. The exercises took inspiration from the improvisational construction of habitation characteristic of selforganized communities, combined with the more formalistic method of patented inventions examined in Richard Hindle's Levees that Might Have Been.

In John Patten's Patent No. 700, 076 for a "Live Wood Wal for Levees" (1902), an invention in which mechanically fastened trees "...grow together to form living enclosures for sediment and levee formation..."32 he states the following:

"My invention relates to a method of forming live-wood walls in various forms; and it consists of fastening together and planting a large number of live trees in such a way that they will grow together, forming a live wood wall or walls of such form as was designed and controlled by the shape of the assembled trees when planted."

Figure 30 which details my imagination of a vegetative pod which can disperse seeds for re-vegetating littoral zones or act as a device for collecting and dispersing sediment can perhaps be aggregated to form an ecological embankment, which begins to foster new ecosystems and 


\section{present new opportunities for architectural innovation.}

Further, the idea of Cultivated Levees, positioned by Frank V. Wright imagines "...a new art of growing crops and raising levees simultaneously,"33 which requires the artful coordination of sediment, 'mud carrying water' and agriculture over a period and cycles. $\mathrm{M}_{\mathrm{y}}$ invention of the Utility-Cul alludes to this by acting as a vehicle for the movement of silts, 'mud carrying water' and vegetation which aggregate over time to form avenues for new habitation or ecological occupation. The images that follow, operate within the aforementioned theoretical framework.

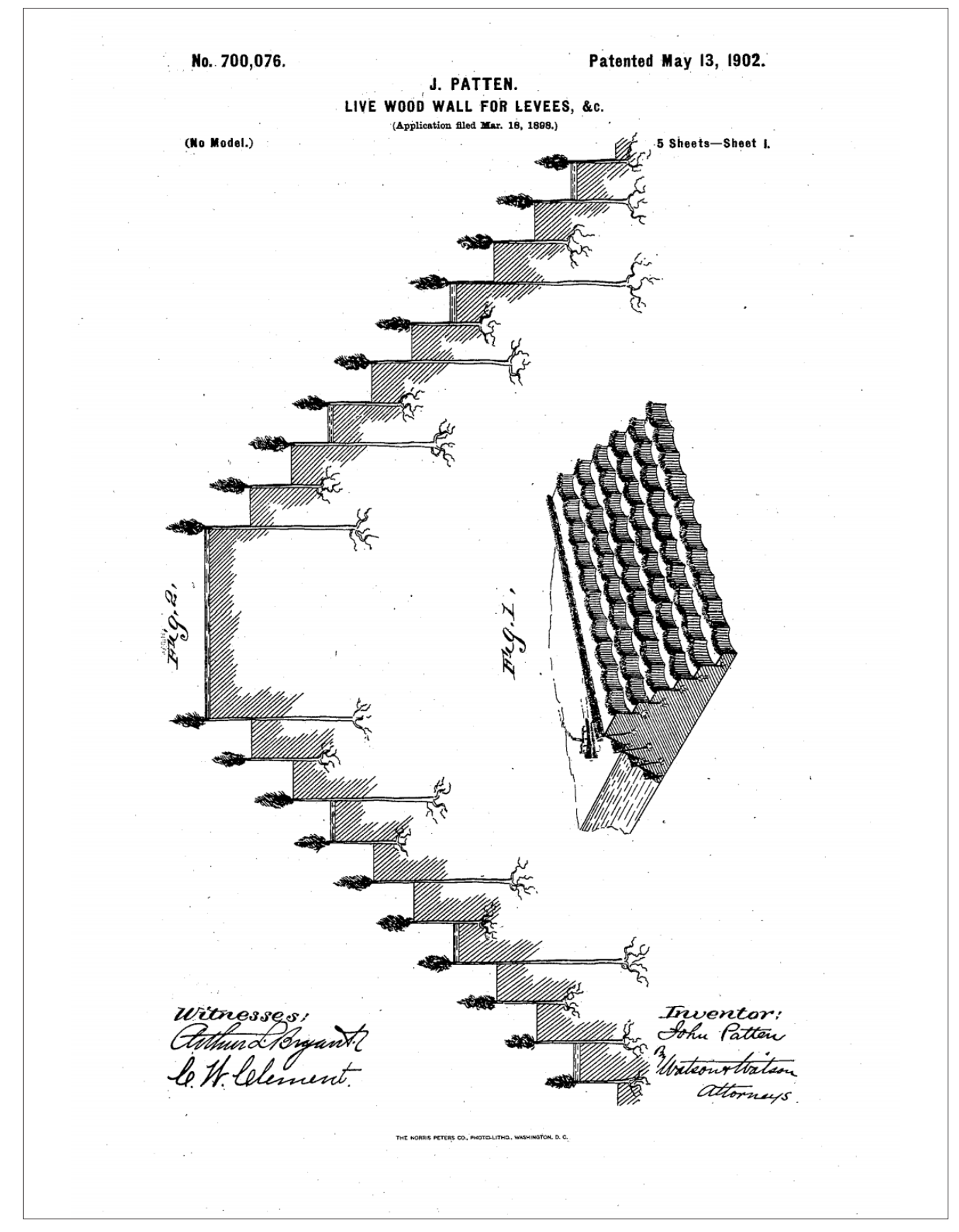

- Figure 30 Patent for Live Wood Wall. From tevees hat Might Hove Been, by richard Hinde.
John Paten, 

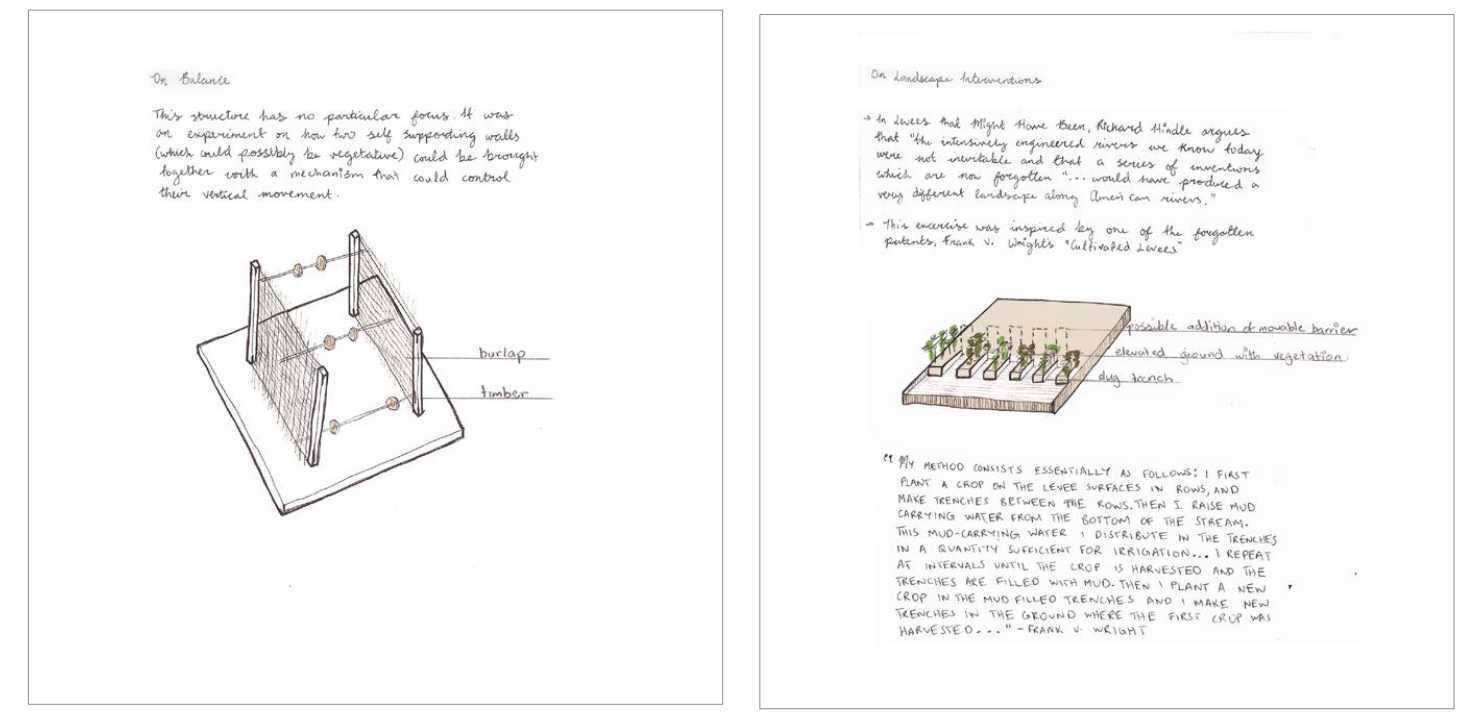

2

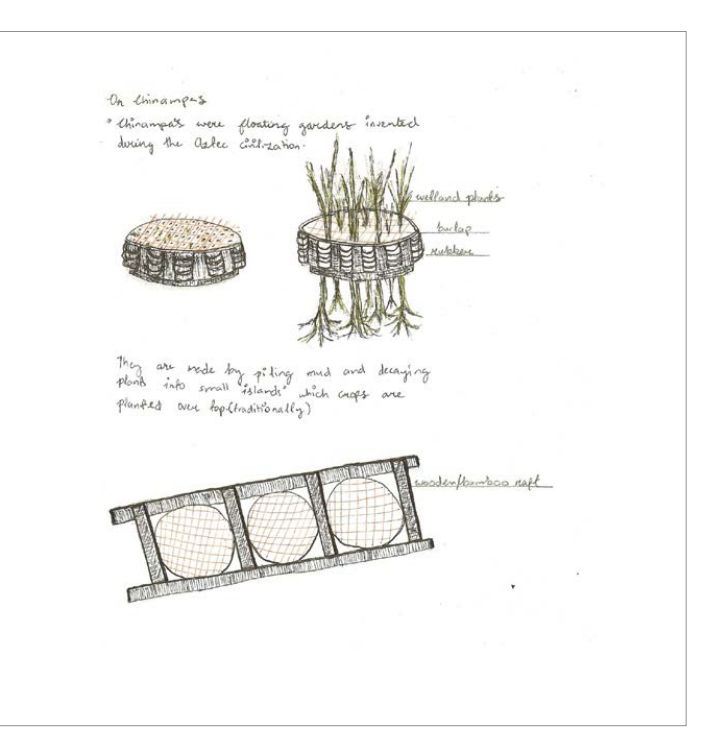

3

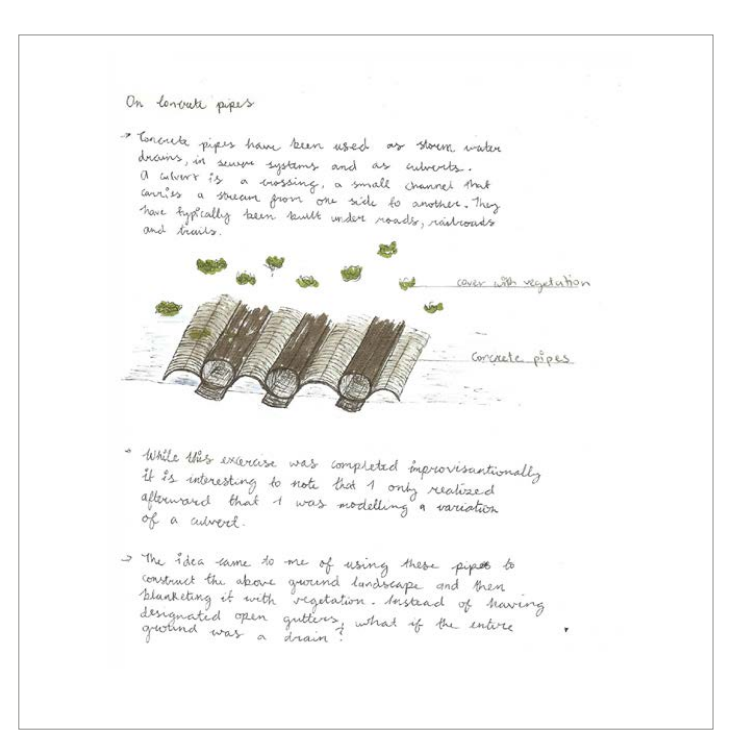

国

$x+5$

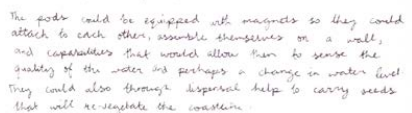

का 
On lontrute pipes

Tonceve pipes have been used ar stoum water

a wivers sewsere systams and as culverts.

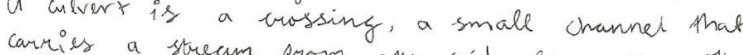

have eypically been buive under for another. They

and truils. $\rightarrow$

$=$

While thins extercise was completed improvisantionall it is interesting to note that 1 only reatised of a culvere.

3 The idea lame to me of using these pipes to construct the above amound landseape and then blanketing it with regetation. Instead of having designated open gutters, what if the intere 

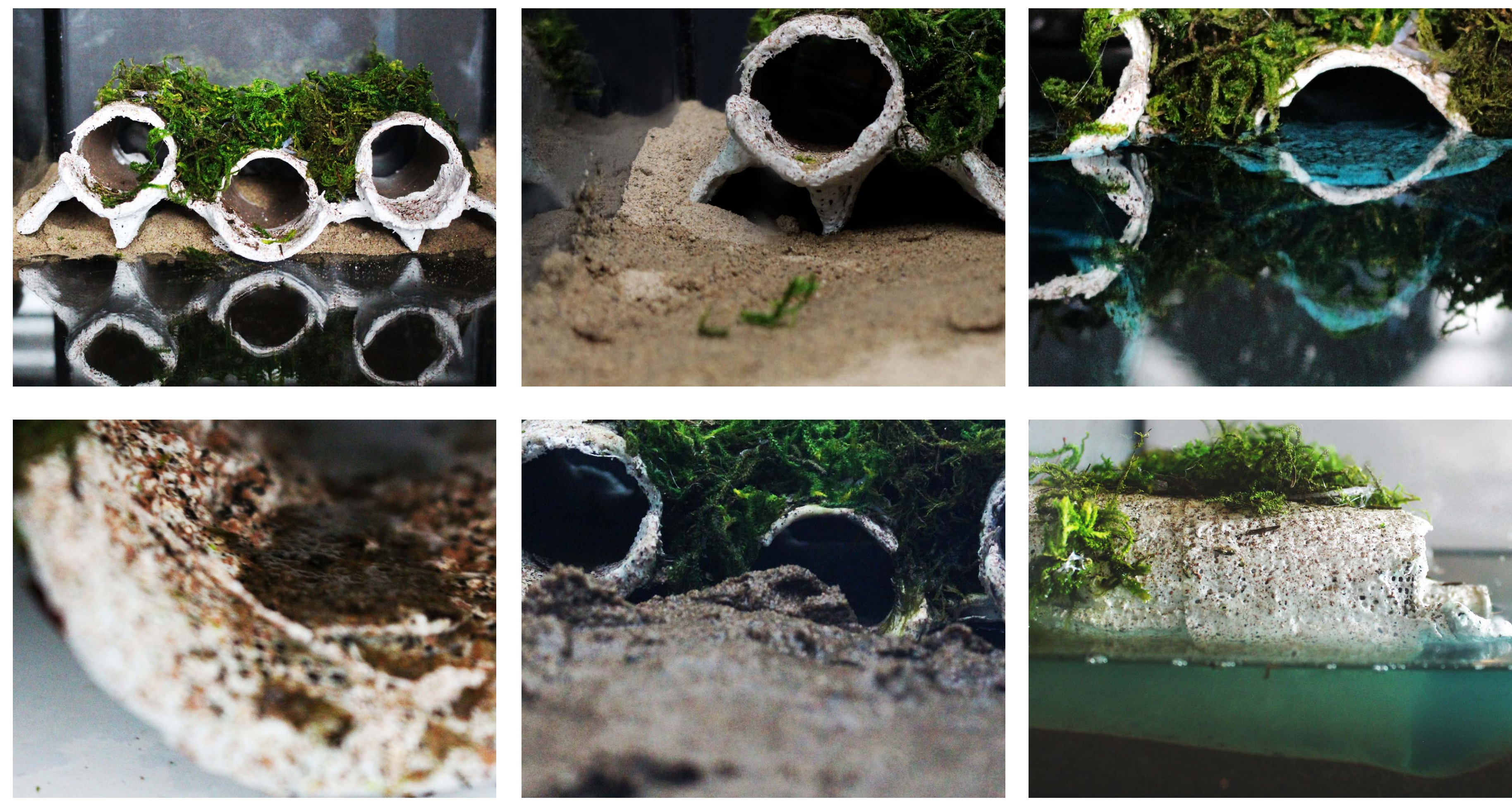


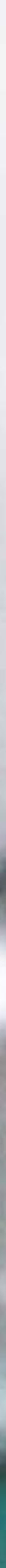

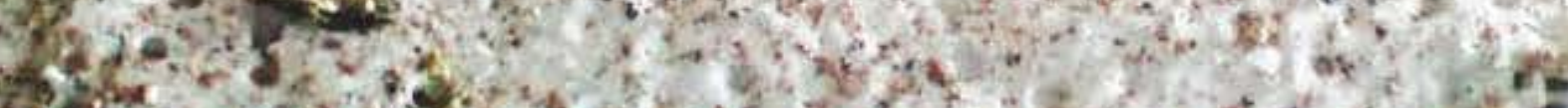
(4.

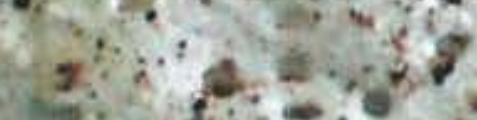
4ivition

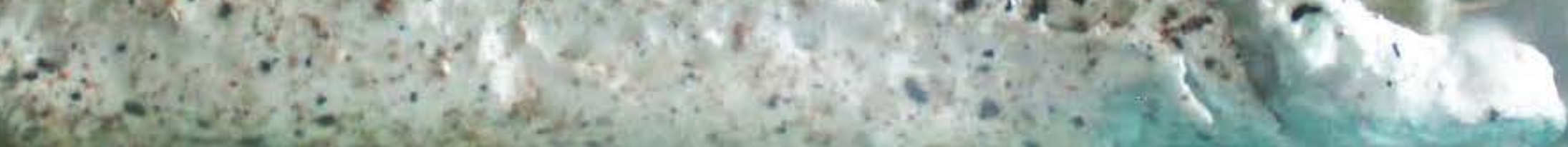

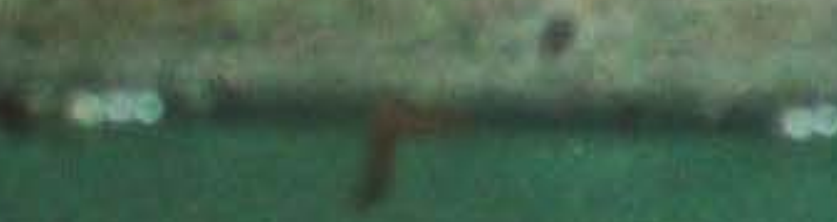




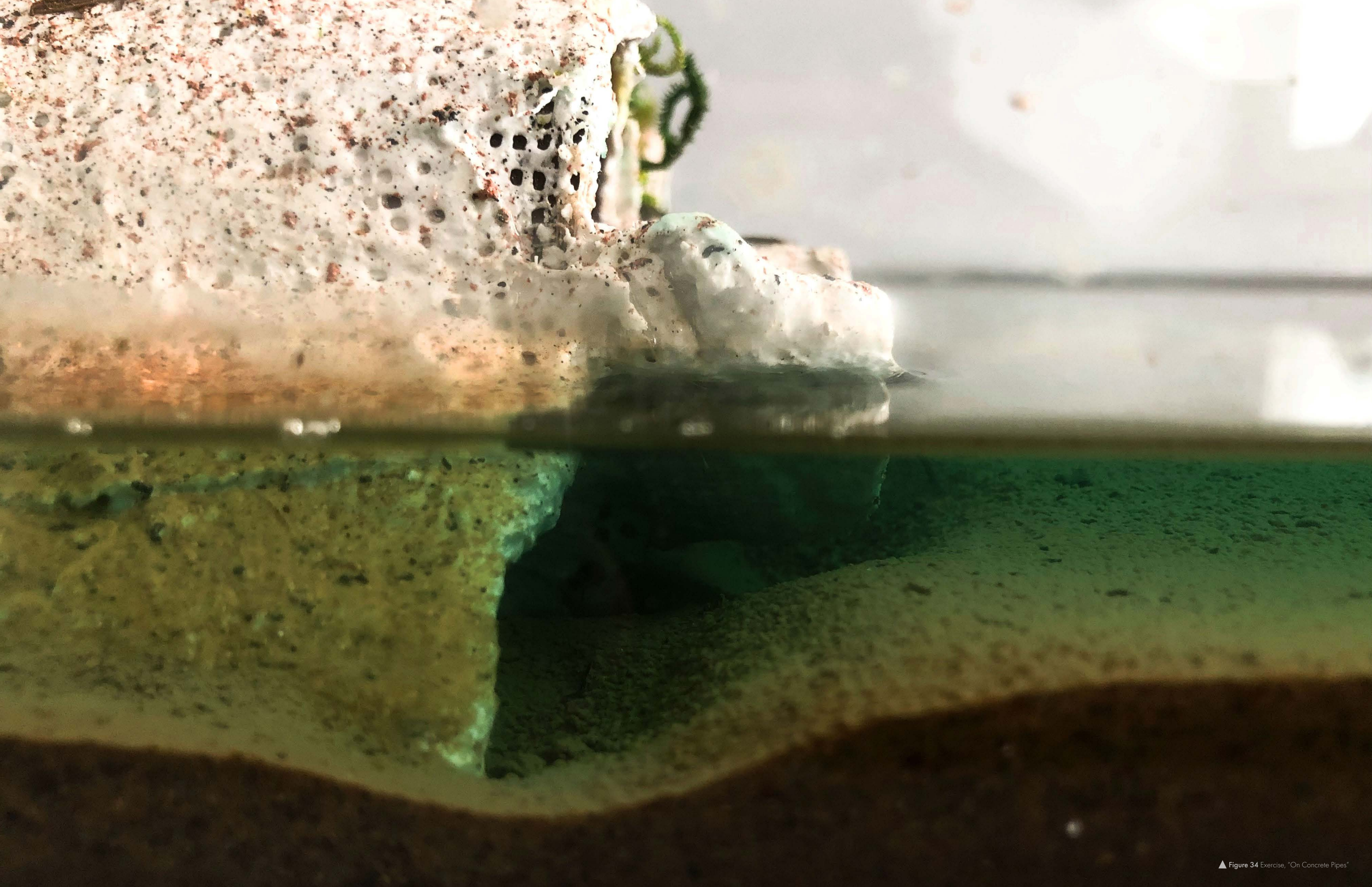




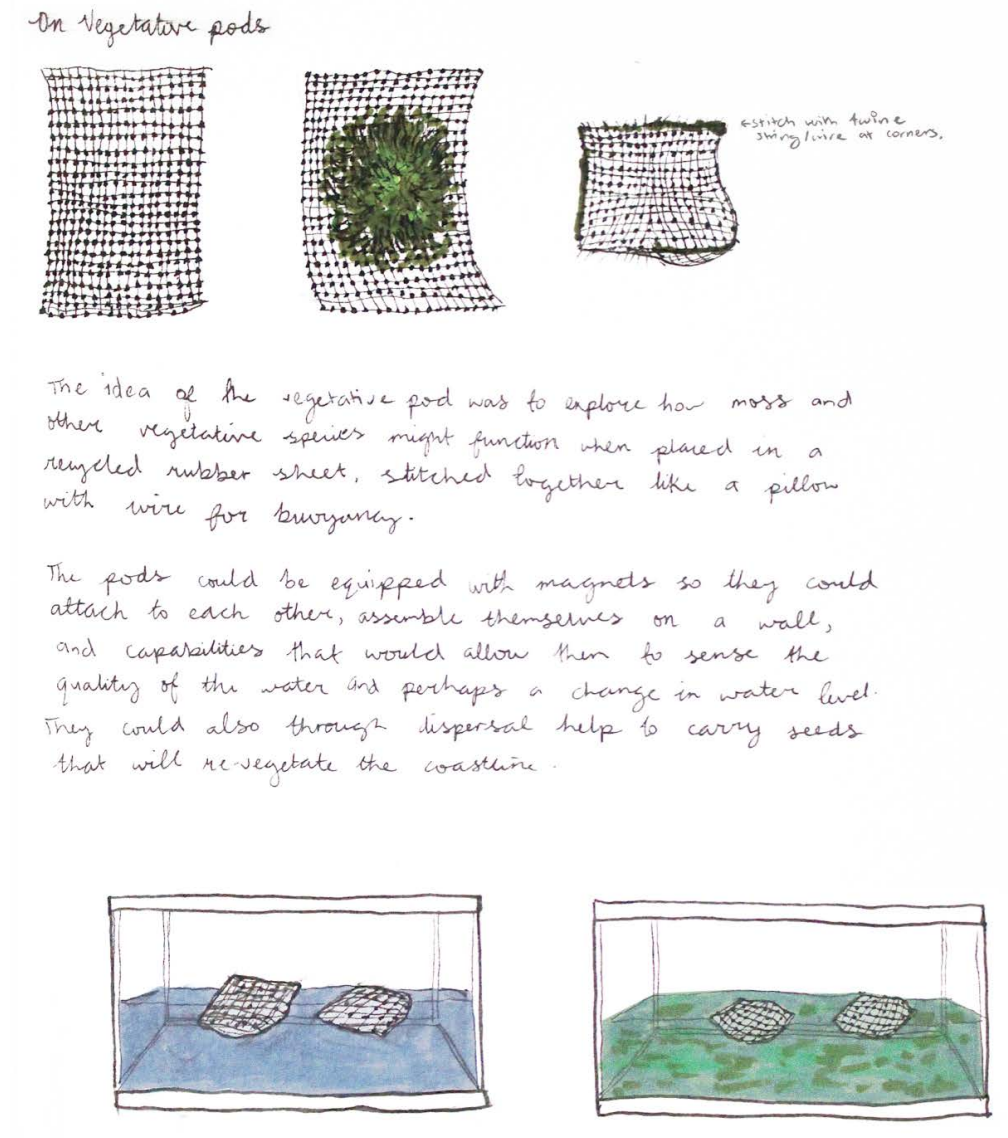



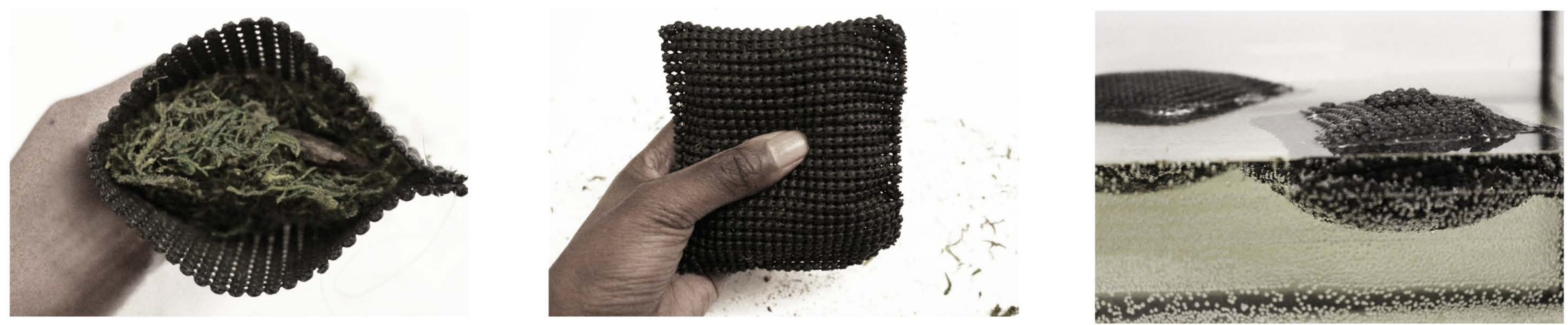

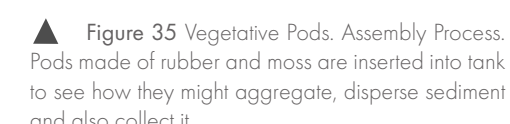


Stop dumping garbage into the drains and stealing my sand (2.) \#littorallycriminal \#whodoyouthinkyouare

12:50 AM · Oct 12022 · Twitter for Geoverse

750 Retweets 47 Likes

〔】 0 个

(9) atlanticthegreat @thelittorallord · $2 \mathrm{~h}$

They can't be diresspering us like this I will terminate their occup

Cl 11

O 50 는 
I am a feat of concrete engineering. I can take on a 1000 year flood 2 \#callmebrutus \#breakwaterbeta @breakwater

10:50 AM - Feb 212013 - Twitter for Geoverse

89 Retweet 57 Likes

$$
\text { 七 }
$$

O

27. atlanticthegreat @ thelittorallord·2h
Replying to @brutus

I'm older than you, I will go wherever I want \#respectyourelders

$657 \quad$ 证 $5 k$

○ 204

(2) utilitycul @culmemaybe·12yrs

Replying to @brutus

weak... channel the force of the Atlantic and still stand my ground don't @ me
Q 80K
七】 $7 \mathrm{~K}$
O $20 \mathrm{~K}$ 
THE FUTURE- IMPROVISING ECOLOGIES

Using the tools and methodologies developed in the first two sections, this section offers a proposal for a future imagination of Apapa rooted in ideas and tools of improvisation, fluidity, and ecology, and what it means to occupy a littoral landscape. What is an architectural response to an outcome that cannot be predicted, in the case of flood, environmental crisis and land scarcity? What becomes of a past shipping and industrial site and the materials it leaves behind? What new economic systems might take their place? The narrative is told through the lens of both human and non-human actors facilitated by the conception of a “Twitter for Geoverse.” 
stis.

Q.

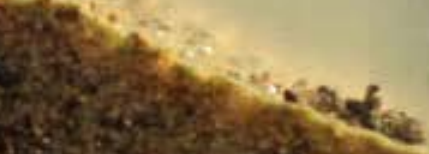




\section{January, 2045}

Activity at the Apapa Port terminal has been rapidly declining, and its economic future is further threatened by the onset of many new economic zones and port developments across Lagos, including the Lekki Deep Sea Port. There is also the reality that Apapa no longer has the capacity to accommodate the thousands of shipments that arrive at its berth daily. The combined effects of infrastructure that is in need of serious repair, roads mired with potholes, trucks which stall the passage of other cars on important thoroughfares, and very slow-moving traffic make it no longer profitable to rely on the area for major shipments and business.

Previously designed as an industrial zone with housing for nearby workers who often worked at the port, this leaves many people without jobs in an area of declining economic activity, yet the area is still growing. Workers have land rights and are reluctant to leave property that has been in the family for generations. The site has history. A new community is growing, yet without land available to accommodate both new economic innovations(required for survival) and habitation. Most of the land in the area is privately owned or owned by either the military or government.

There is only one area left which has so far resisted complete commodification and it presents the best opportunity for both economic and social sprawl; the edge. 


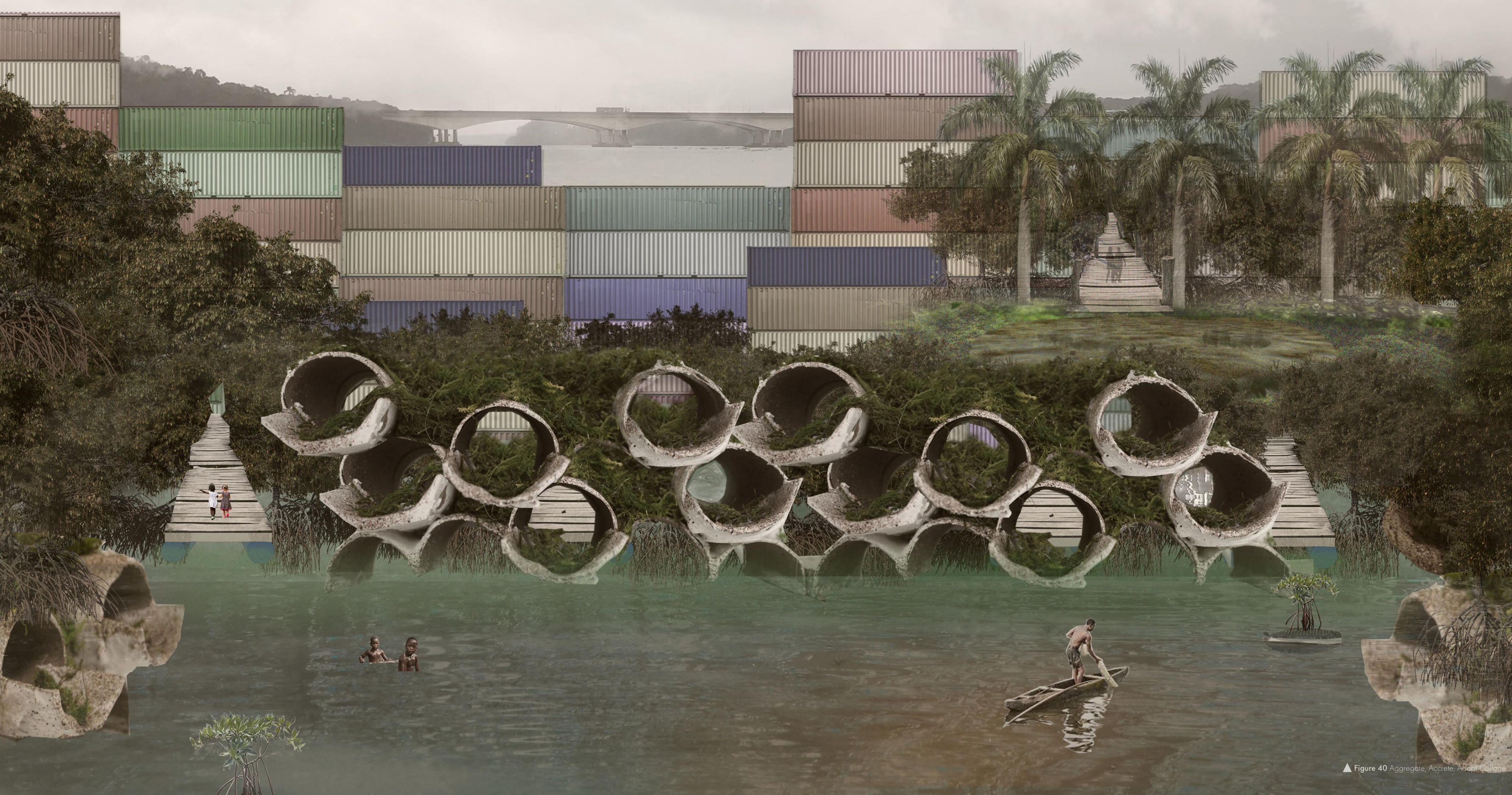



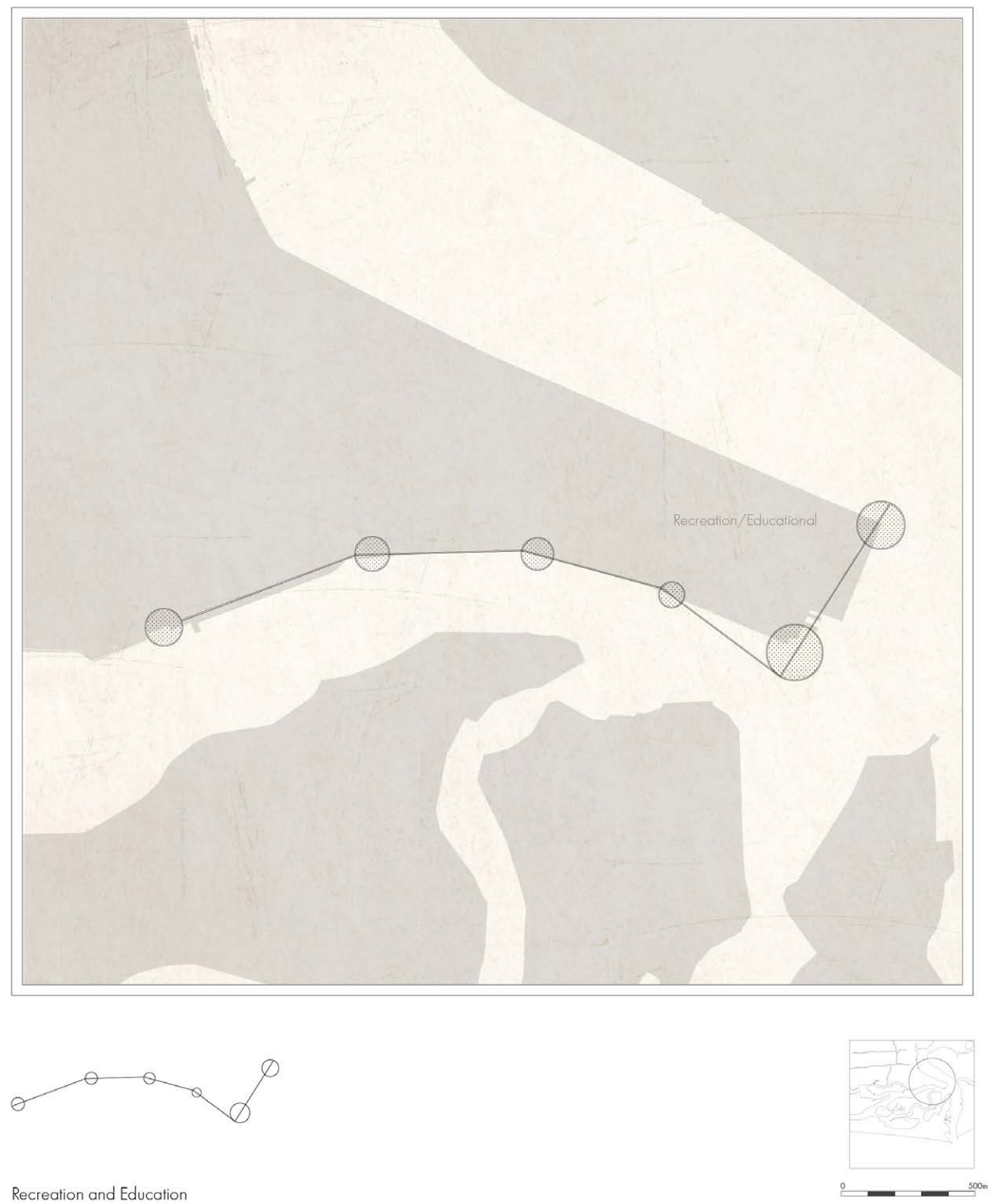

Interventions which offer opportunity for play and learning are docked alongside the edge of the quayside. The dea of docking becomes important in the installation of emporary-permanent interventions- docking extends is purpose beyond the receiving and sending off of goods for a capitalistic market but a device for poridro opportunities for play and habitation. 


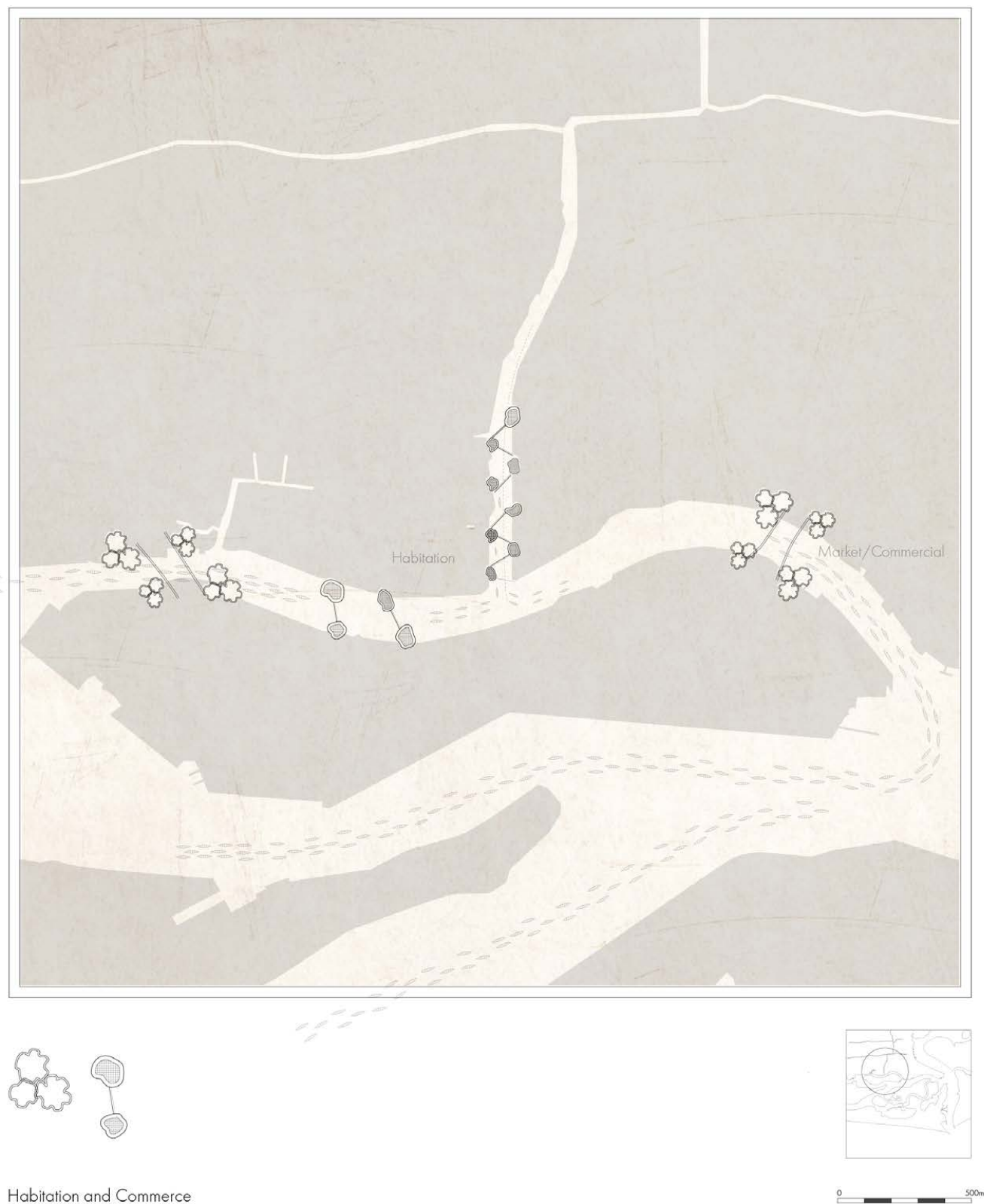

Figure 42 Canal Edge, Plan

Habitation and Commerce

$--$

Caes flock tike fistes on Salurdays to new busting 


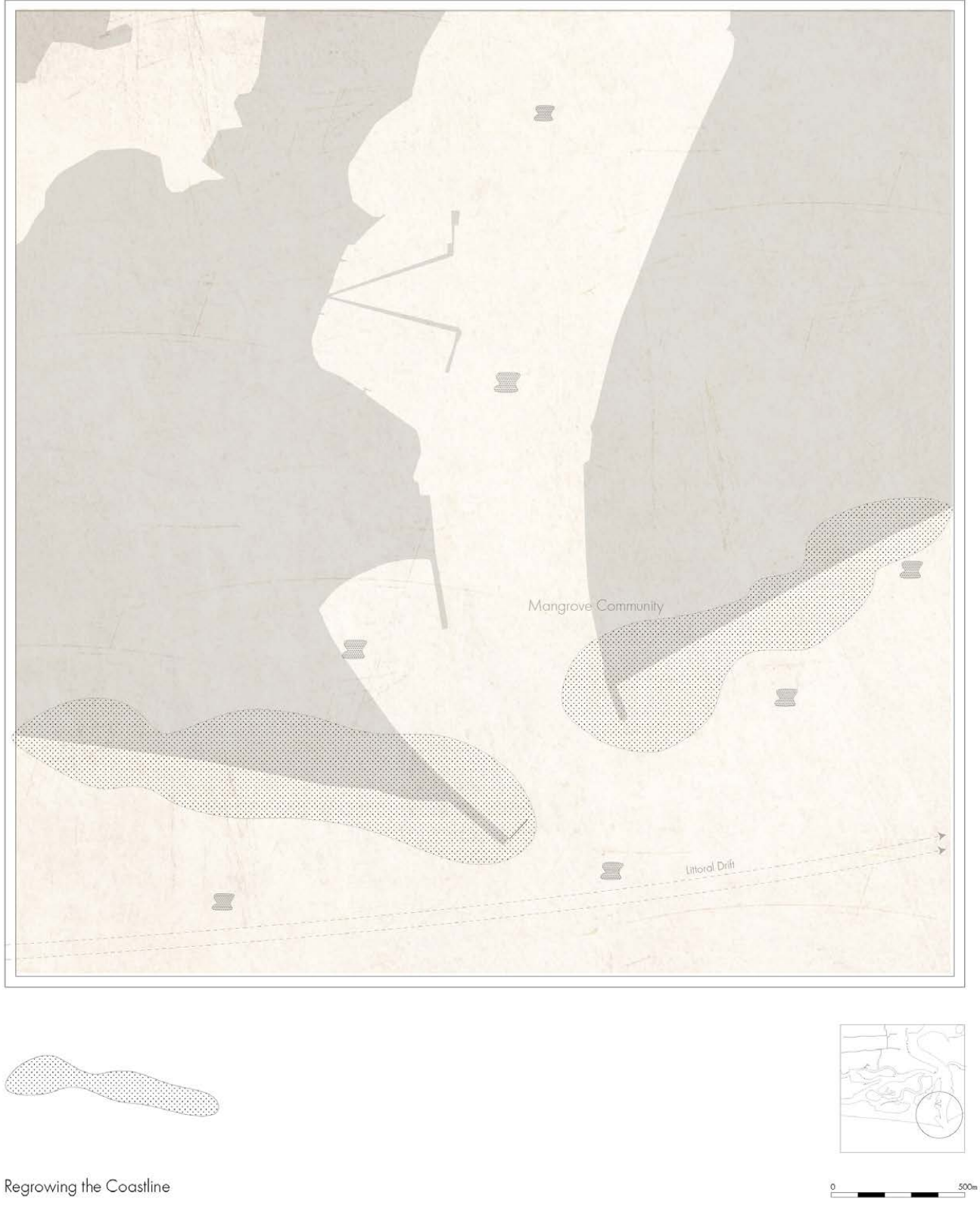

A Ger possibinity for the coasial edge is imagined beyon 


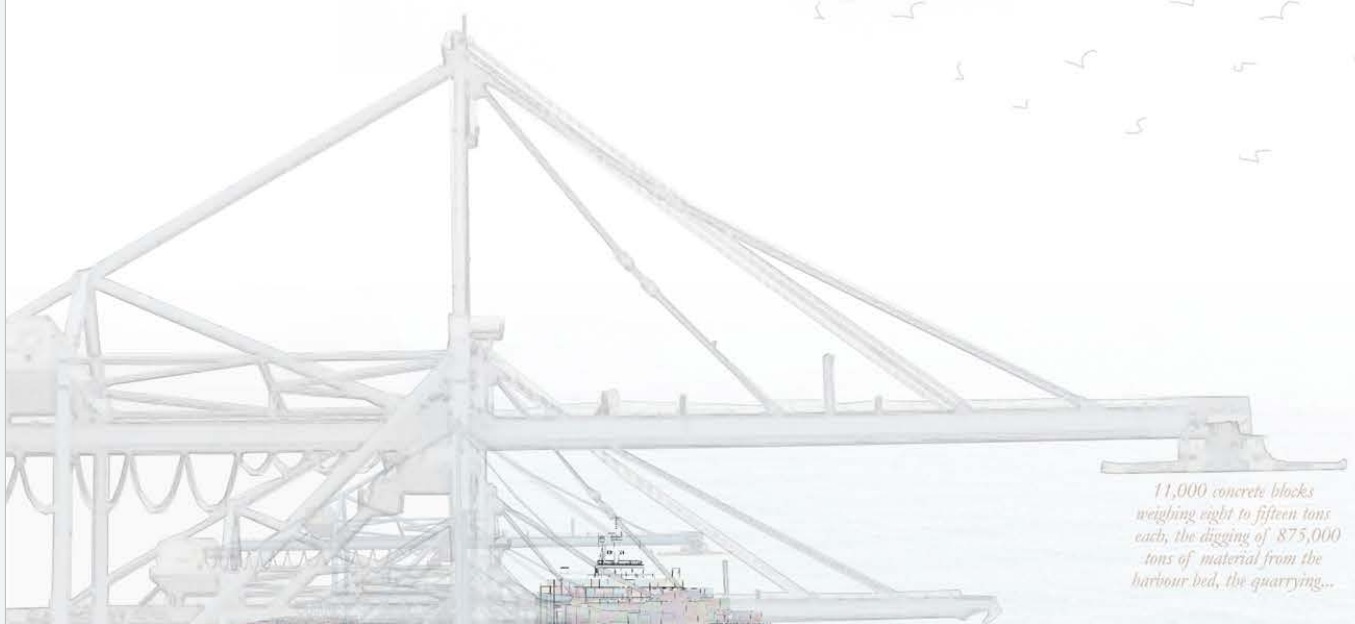

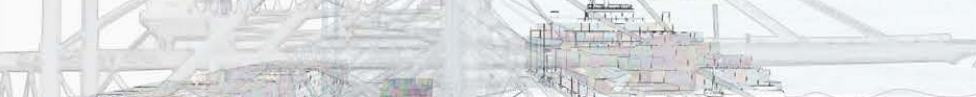

W

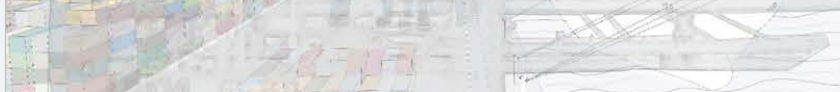

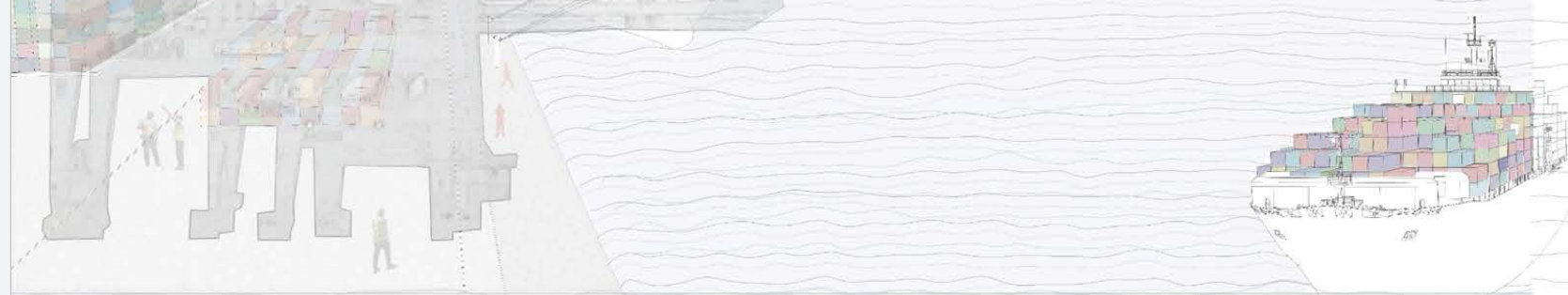





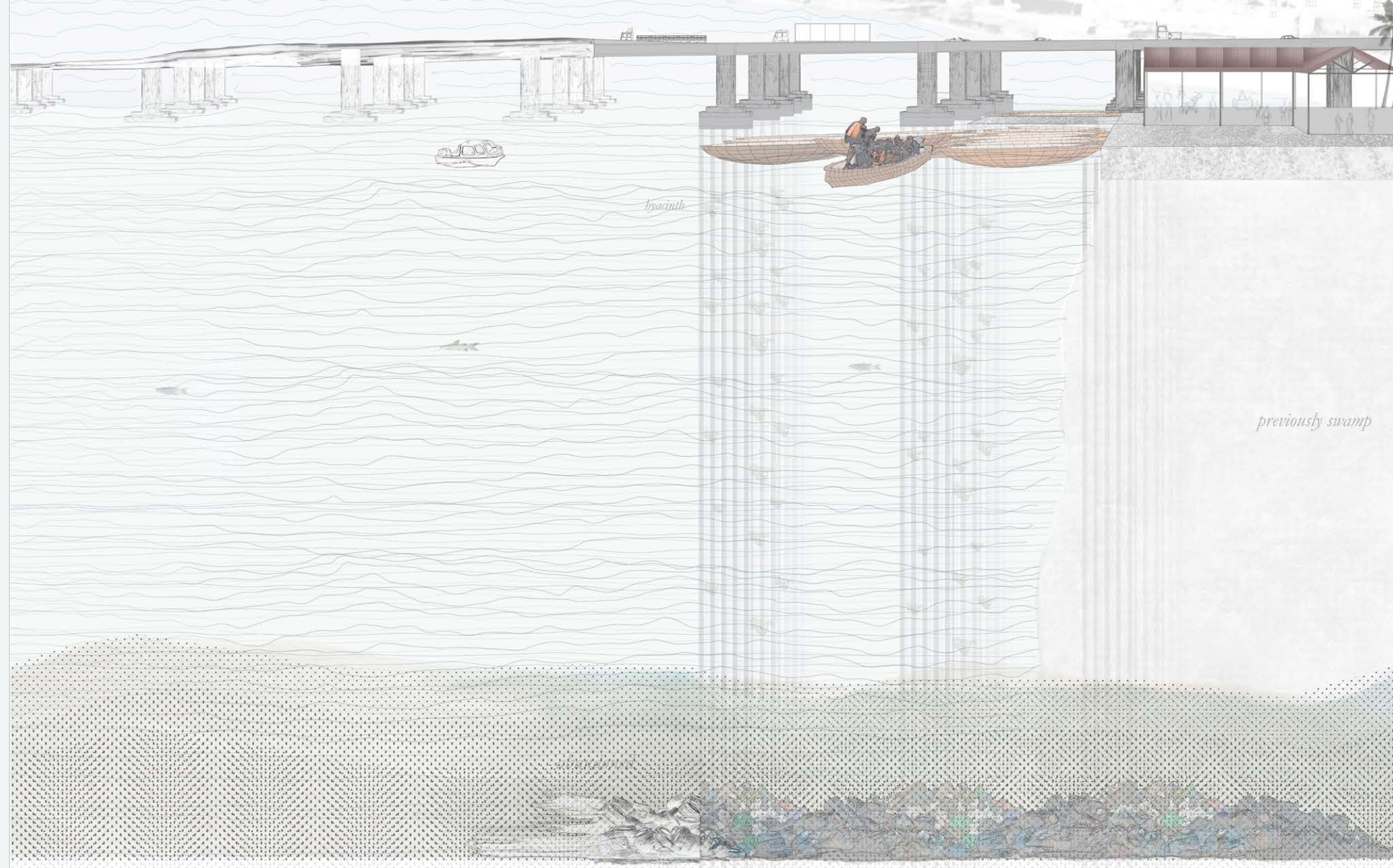




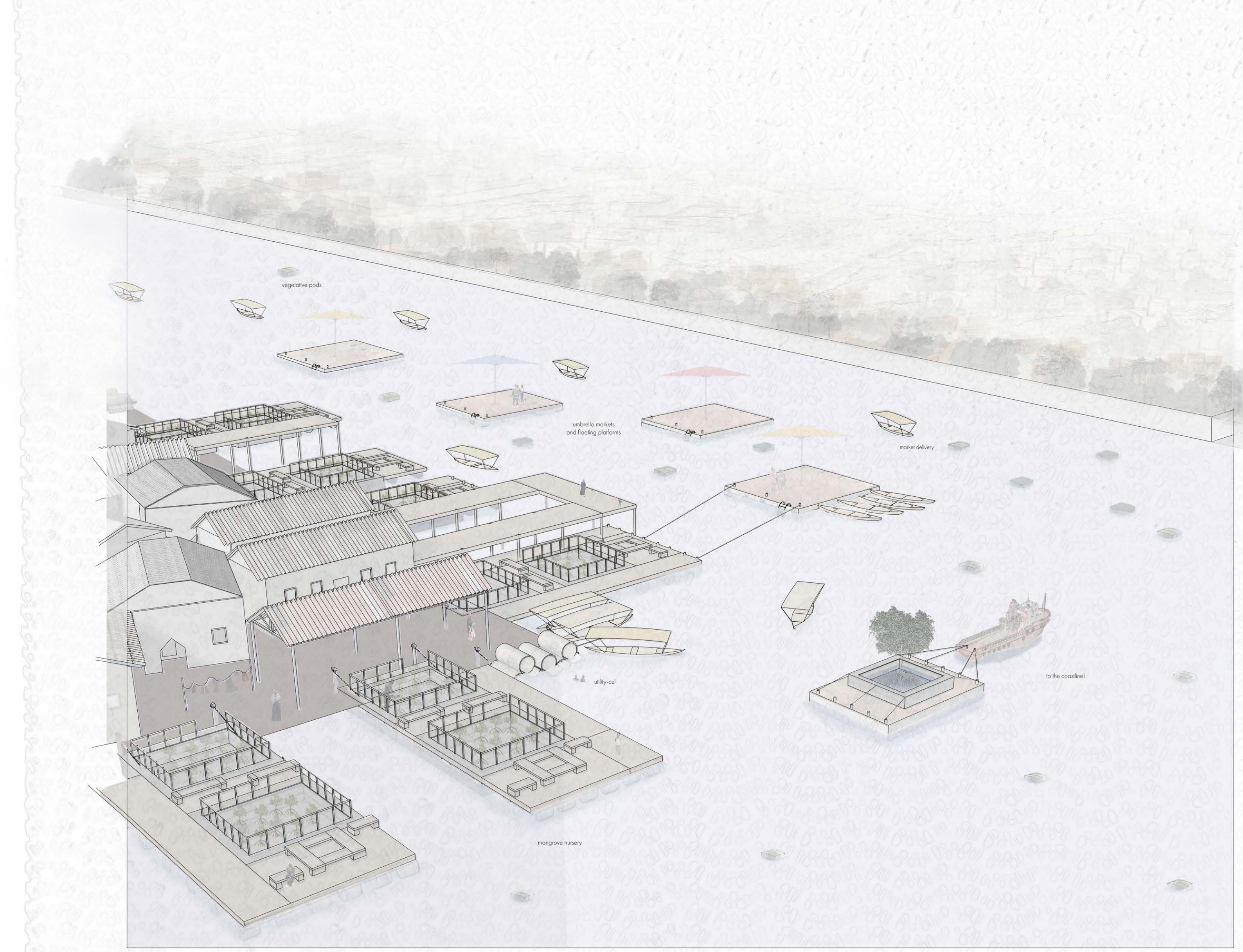


mangrove_expat

it's my birthday friends!! just turned 14! moving to another home on saturday...super excited :))) \#coastlife \#allgrownup \#teammangrove 0.0

3:40 PM · July 42052 - Twitter for Geoverse

80 Retweets 15 Likes

O

2. teammangrove@friends_at_the_nursery·30s plying to @mangrove_expat

oh no way! we can't wait to join you in eight years

$$
\text { Q } 1 \text { 亿】 } 15
$$

(1) farmerboy_seun@itsseun·5

you'll do great! we're so proud of you' more sediment to your roots!
D 5
〔๖
O 0 


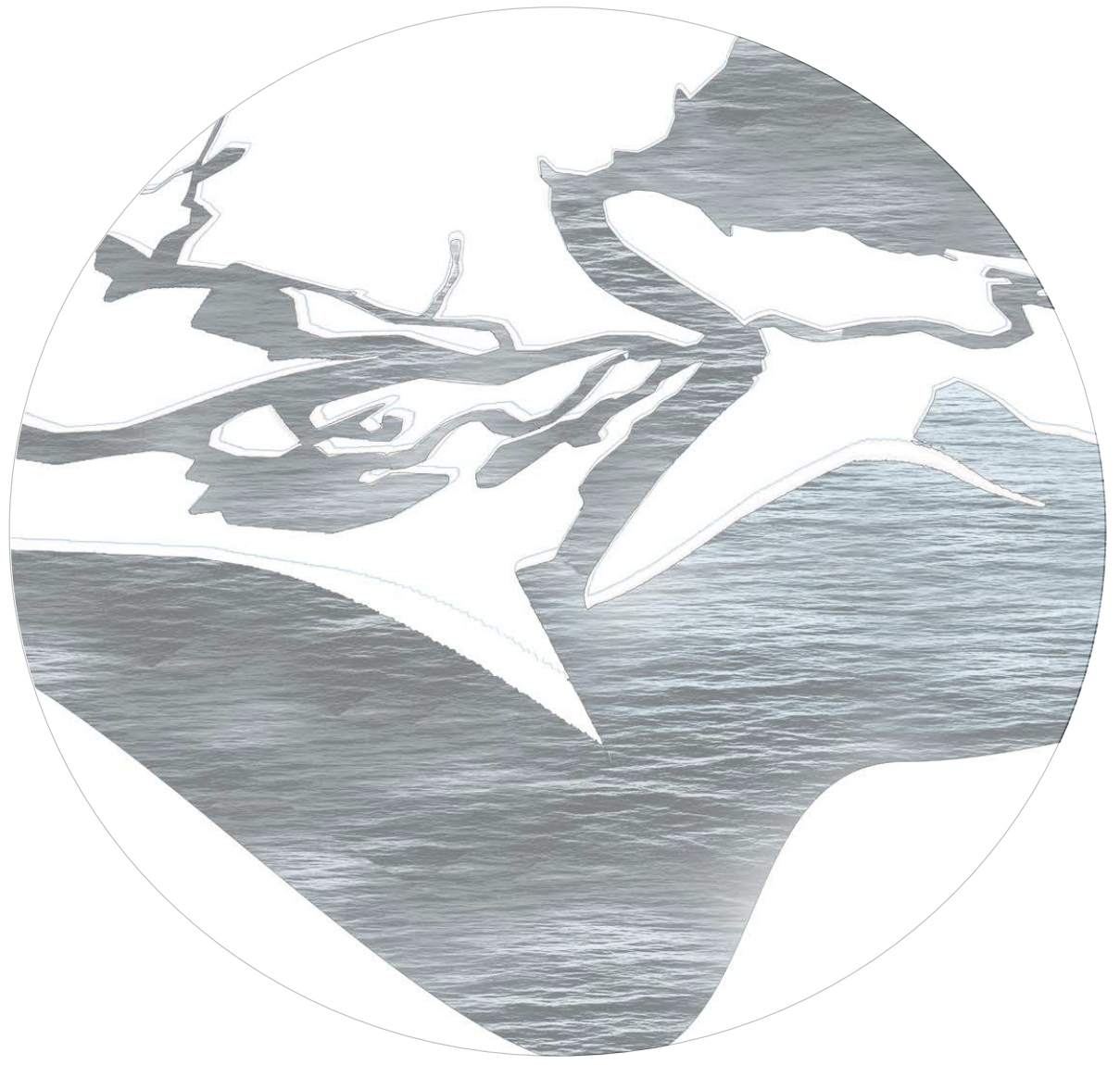

The Lagoon has been bere longer than all of us. 


\section{The Mangrove Nursery}

Mangrove nurseries cross hatch along an edge community which have the option of being taken to the coast of the city when they reach their full maturity between 10 and 15 years. In between that time aquatic creature gather their perimeters swimming through their roots like children running around a park. Fishermen gather every few weeks benefitting from these new ecologies and taking only what they need.

\section{The Feasting of the Lagoon}

In the late summer to early fall months, the lagoon opened its mouth to feast on the nourishment of the land. And it seemed that the ground was so pleased that it would rise to dine with it.

During the months of July and October, the festival of the Feasting of the Lagoon is celebrated on the first Sunday of every month. During these months, the community disperses excess sediment gathered by utility culs and spreads it across the land. Every year the ground is raised by 4-6" through a community effort, and certain habitations must be readjusted to accommodate and adapt to the change. Progressively the elevation of the land changes, and every time the lagoon returns to "feast," the ground always welcomes it- never to be overwhelmed by such a presence.

The Floating Platform

As essential as the canoe, the floating platform simply allows for the temporary occupation of different locations on water. Constructed with simple materials—barrels and planks of wood, or alternatively compressed stacks of plastic - in bale form, the floating platform is the 


\section{essential device for "setting up shop" anywhere.}

\section{The Hyacinth Catcher}

Like the bounty hunters of the old days, water hyacinth is a highly sought-after commodity. Once an invasive species—almost as pervasive as the mosquito it has become an all-purpose material. It is used for biogas, cleaning sewage and for making woven items like baskets, which are used at the farmers market on Sundays. Sundays—everything community oriented happens on Sundays. Sunday has always been sacred. In the Tolu Complex which contains highly specialized schools, focussed on everything from boat building to developing new forms of biogas, important work is consistently happening concerning the lates technologies in sustainability and high-tech agriculture.

\section{The Dirty Drain}

There were always complaints about people dumping things into the drains, so much so that the gutters had to be converted into recycling chutes. It is hard to imagine why those large holes in the ground always invited the deposition of cans of cola soft drinks, pure water plastic bags, and all other sorts of curiosities. Consequently, this meant that the neighbourhood would need new ways of draining water. Recycling has become an especially important industry here only second to high tech agriculture. A declining port has offered much material for innovating minor infrastructures. There are recycling stations everywhere. This also forms part of the landscape- the trash landscape.

\section{The Fisherperson}

Contrary to popular belief the fisherperson never went out of busines despite the hyacinth, the threat of warming waters and biodiversity depletion resulting from industrial economic activities. New ecosystem are being generated and new species are being discovered, and the utility-cul is one device that helps with this. In fact, the fisherperson is one of the most important businesspeople. They provide food for the community and help to steward aquatic ecosystems. 


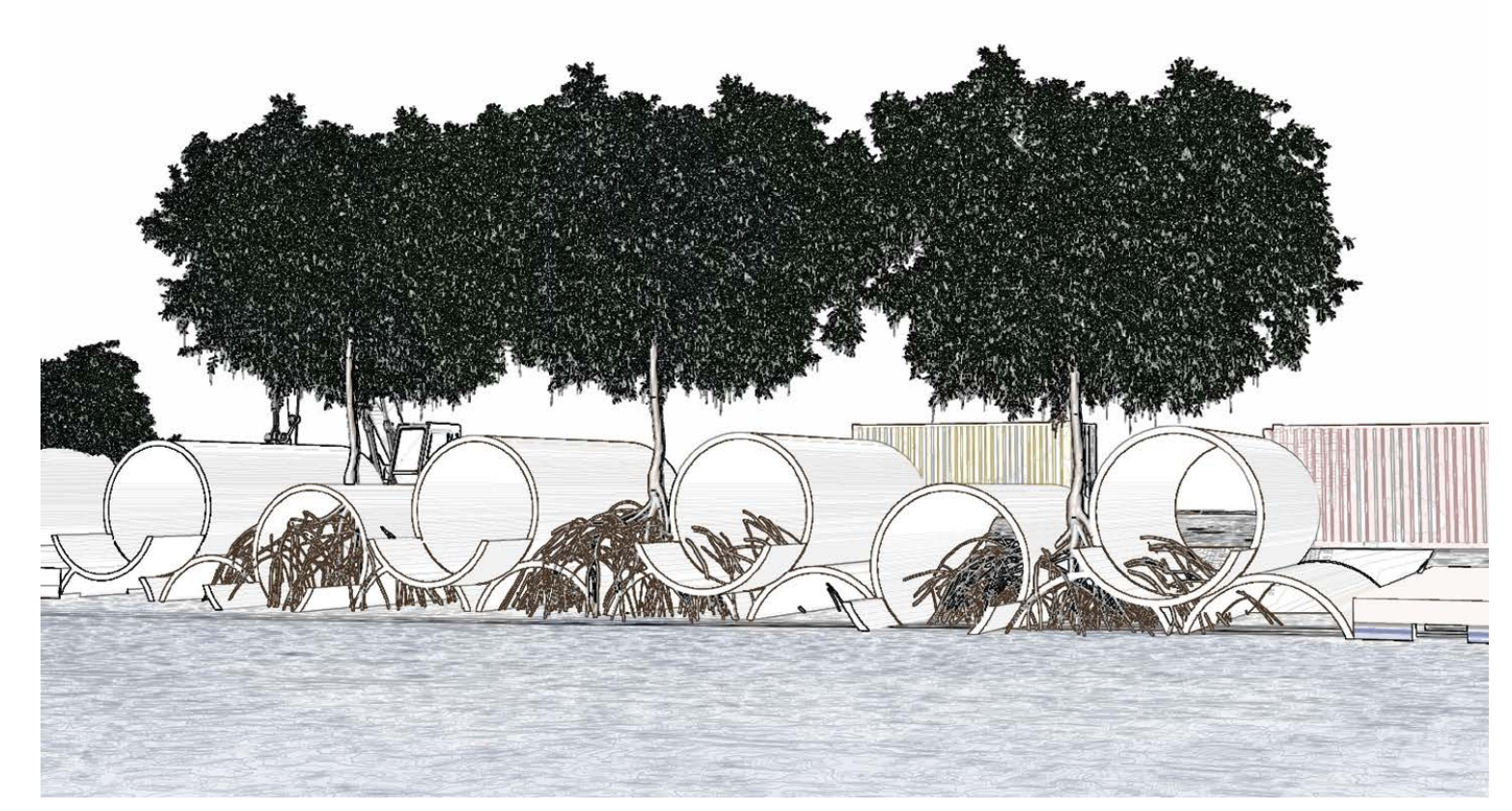

The Utility-Cul is a tool, thing, and device that helps to facilitate the architectural environment. It can be programmed or generate programs by creating space. It accretes sediment carried by the flow of the lagoon. Over time the device can help to facilitate the creation of new topographies that evolve through natural processes_-giving rise to new kinds of habitation and possibilities for such. 


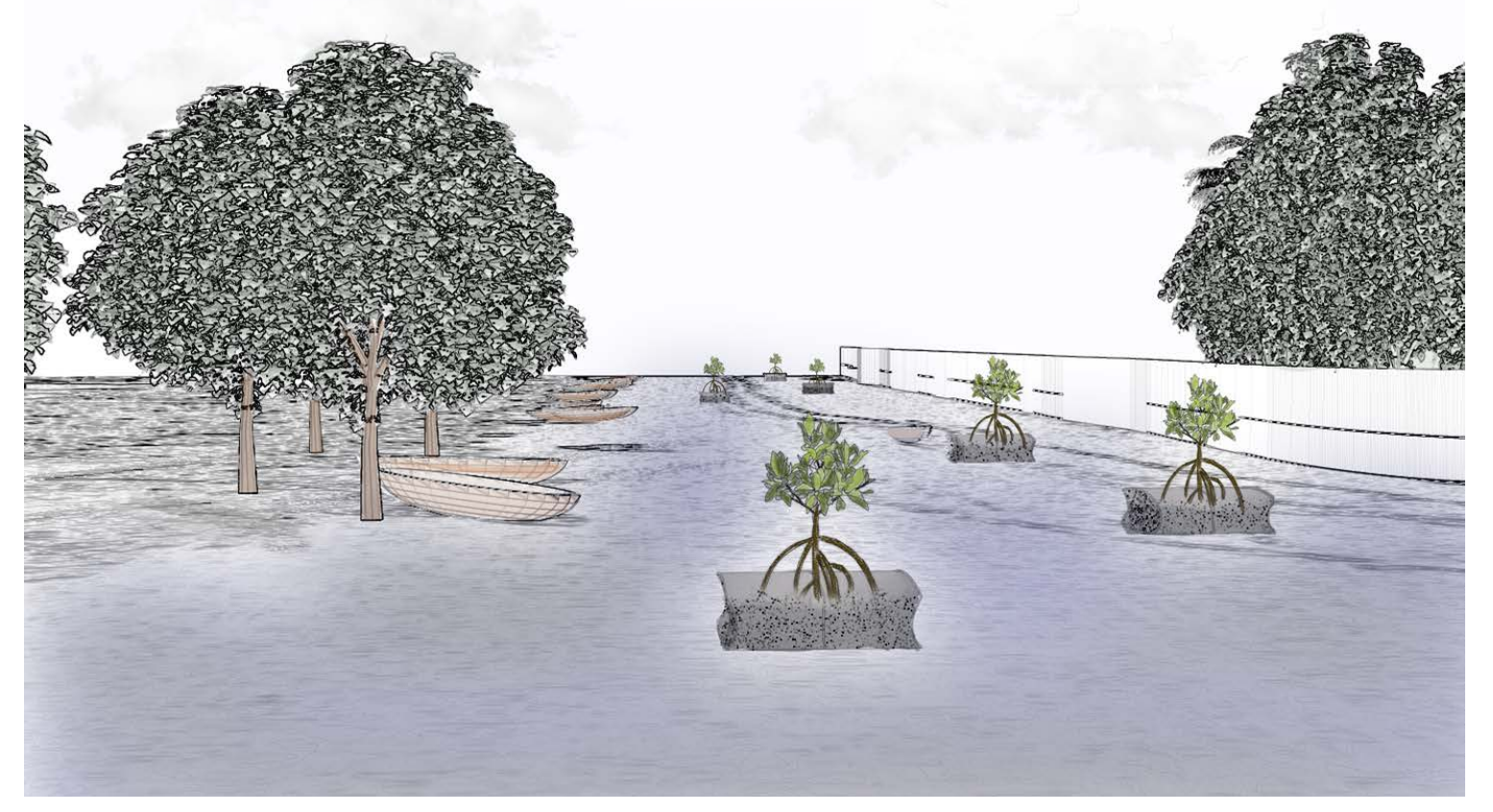

Pods made of recycled material make their way down the lagoon, collecting sediment to redistribute along edges. In alternative roles, they act as agents of seed dispersal, working diligently to introduce new and beneficial ecologies to different areas of the city. 


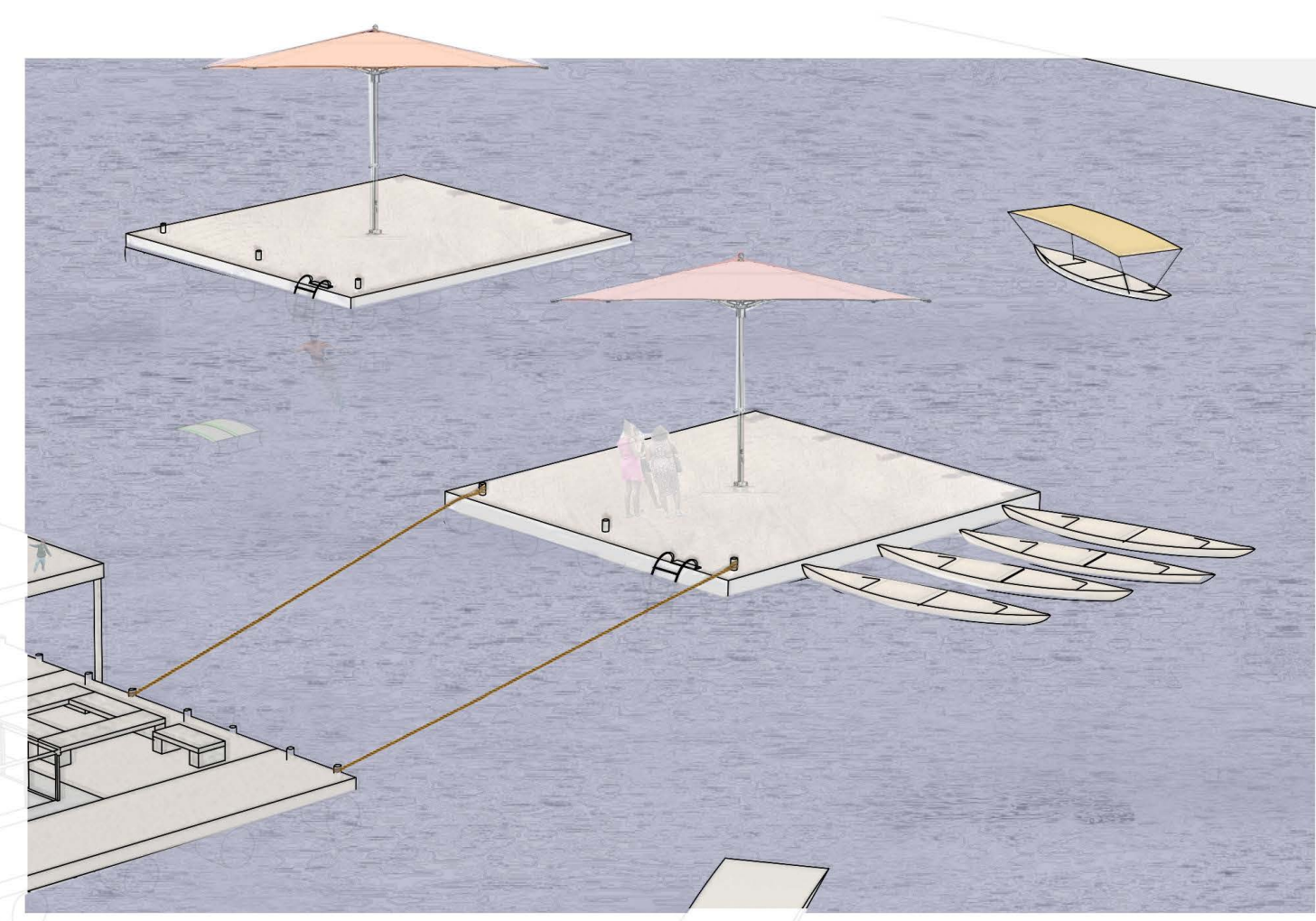

Everyone knows of the umbrella market and its undisputed value on the street corner or in dedicated areas of the city, especially when in search for unique meals and snacks that can only be found in certain areas. The Umbrella Market is no longer limited to the street but has diversified itself using floating platforms. Umbrella markets attach themselves to different piers along the coast. The lagoon becomes an avenue for commerce, and it is very much as alive as the activity that occurs on it. Rather than being monster of the sea, as it snakes its way from the Atlantic through the urban core, the lagoon is a refuge—it only asks that you make its acquaintance. A flexible module allows two people to enjoy a sunset while an assemblage of modules creates a flotilla for vendors on market day or for festivals. 
instead of an ocean warming, this year i'll be hosting a pool party and everyone is invited \#wavy @toocoolforschool

@friends_at_the_nursery @thelifegiver@culmemaybe @itsseun

6:00 PM · September 102080 - Twitter for Geoverse

500 Retweets 200 Likes

Q 〔】 $\quad$ 个

2nah @toocoolforschool·2m

Replying to @thelittorallord

super excited to cool off !! \#breathoffreshair

Q 12 ¿】 2

farmerboy_seun@itsseun·5m

Replying to @2nah

what a catch ;)

Q 1

โ】 2

03

teammangrove@friends_at_the_nursery · 30s

Replying to @thelittorallord

love me some waves;)

Q 1

〔】 3

O 6

12utilitycul@culmemaybe·1m

Replying to @thelittorallord

๑】 20

O 4

^
Q 5

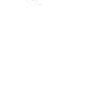


This thesis revealed the generative potential of visual storytelling to explore and offer new ways of seeing and understanding within a critical framework. The treachery of traditional forms of representation is that things only have meaning in the context of certain systems and inverting those systems also necessitates a change in the way things are presented.

The first portion of this thesis attempted to subvert old ways of representing the coastal city, by creating a system in which to understand a series of maps in a way that reflected on the conditions of what it meant to occupy a city in political, environmental and economic flux The mapping exercises explored a system that showed material qualitie as defined by water rather than as an act of zoning or territorialization.

Through the alternative presentation of maps in a traditional plan view, the difficulty of conveying complex environments in fluidity and flux like a mangrove forest or a housing community on stilts was established. This led to the creation of a conceptual map model in which tactile materials analogous to the notational gradient created in the exploration of the previous map, allowing for another re-reading of two-dimensional space. This way of working allowed for an engagement with spatial social and ecological questions from a vantage point that was more personal than a helicopter view. Understanding that the rigour and accuracy of mapping requires an oscillation between a "wide" and "close" view of space, especially regarding the scale of a city, models and materials studies added definition and complexity to the abstractness of 
the aerial view.

The thesis also revealed the potentialities and limitations of different visualization techniques. Several re-mappings of Lagos led to the realization that the medium matters and the medium also carries within itself a message - a particular ontological and epistemological orientation in which the work must be viewed.

A network of maps, narratives, collages, models, drawings, and tweets from the Geoverse allowed a reading of space within a multiplicity of vantage points, acknowledging the fact that each medium of storytelling presents a different perspective. Working together simultaneously, space -the domain of habitation, also reveals itself as a domain which is coconstructed by many actors-the human, non-human and the entire network of social, political, historical and environmental systems that influence the milieu in which architecture operates.

A proposal for how to aggregate, accumulate and adapt within the social construction of space also resulted in the imagining of a possible economic system which existed outside a wholly capitalistic/extractive framework. How could people and the ecological systems in which they were oriented work together towards a more sustainable and collaborative future? How would the results of this thesis change if the economic systems shifted?

The results of this thesis are one part of a collection of edge morphologies of how socially constructed spaces along littoral edges, within specific socio-political and environmental conditions might emerge. As the conditions and the narratives change, the architecture necessarily changes. The constellation of stories (in plan, section, drawings, tweets, etc.) that capture this flux might accumulate or aggregate themselves into something like an atlas of socially constructed spaces or an anthology of spatial occupations which operate within cycles of seasons or rising water. Finally, the idea of scale has prominence in these stories for a littoral future. An intervention at the scale of someone's front yard (i.e a mangrove nursery) could accumulate into an aquaculture farm at the scale of an entire community, which then works as part of a greater strategy to rehabilitate a coastline.

Avoiding the pitfalls of solutionism, the final offering then is not a proposal, but several starting points, from which to approach community-driven design as process, rather than resolution. 
Used in Drawings

Nigeria Federal Surveys. The Nation's Capital, a Street Guide to Lagos. Lagos: Federal Surveys, 1977

Nigerian Mapping Company. Enemsi's New Map of Greater Lagos. Yaba, Nigeria: Nigerian Mapping CoLtd, 1981.

OpenStreetMap. "OpenStreetMap." Accessed September 30, 2020 https://www.openstreetmap.org/.

Reclus, Elisée, and A. H. (Augustus Henry) Keane. "West Africa." In The Earth and Its Inhabitants ..., 270. New York, D. Appleton and company, 1882. http://archive.org/details/earthitsinhabita13recl_0.

Used as Reference

Sketch of Lagos River, Lt. J. H. Glover, 1859 Map of Lagos/Upper Guinea, 1885

Plan of the Town of Lagos West Coast of Africa 1886, Prepared for the Lagos Executive Commissioners of the Col \& Indian Exhibition 1886 Lagos \& Environs 1: 12, 500 Sheet 1, Fifth Edition. Drawn \& reproduced by Federal Surveys Nigeria, 1960

Lagos \& Environs 1: 12, 500 Sheet 2, Fifth Edition. Drawn \& reproduced by Federal Surveys Nigeria, 1960

Lagos \& Environs 1: 12, 500 Sheet 3, Fifth Edition. Drawn \& reproduced by Federal Surveys Nigeria, 1960

Lagos \& Environs 1: 12, 500 Sheet 4, Fifth Edition. Drawn \& reproduced by Federal Surveys Nigeria, 1960 
Lagos \& Environs 1: 12, 500 Sheet 5, Fifth Edition. Drawn \& reproduced by Federal Surveys Nigeria, 1960

Lagos \& Environs 1: 12, 500 Sheet 6, Fifth Edition. Drawn \& reproduced by Federal Surveys Nigeria, 1960

Lagos 1: 12, 500 Sheet 7, Sixth Edition. Drawn \& reproduced by Federal Surveys Nigeria, 1960

U.S. Army Map Service. Lagos 1:12,500, Edition 1-AMS, Series G961 1962 
Figure 1 Falola, Fiki. The Colonial Hand: Land, Water, Waste. 2020

Figure 2 Falola, Fiki. Geoverse Tweet, Breakwater-Victoria Island. Twitter for Geoverse. 2021. Map: "The History of The Great Wall of Lagos - Eko Atlantic." Accessed March 15, 2021. https://www. ekoatlantic.com/education/sea-wall/.

Figure 3 Falola, Fiki. Precarious Possibilities Digital Collage. 2021

Figure 4 Falola, Fiki. Dredge, Drill, Drain. Digital Collage. 2021

Figure 5 Swamp Drainage Map, Lagos. Gandy, Matthew. "Mosquitos, Modernity and Postcolonial Lagos." The Fabric of Space: Water,

Modernity, and the Urban Imagination. The MIT Press, 2014. https:// www.jstor.org/stable/j.ctt9qf9xf.

Figure 6 News Article, Excerpt from "Little Lagos has Big Importance." "LITTLE LAGOS." Daily Mercury (Mackay, QId. : 1906 - 1954). April $8,1942$.

Figure 7 News Article, A Most Modern Port. "A MOST MODERN PORT." Kojonup Courier (WA : 1951 - 1958). June 13, 1956.

Figure 8 Photograph of Apapa with Rail. The National Archives UK. CO 1069-65-85. February 7, 2011. Photo. Africa through a lens. https://www.flickr.com/photos/nationalarchives/5425693368/.

Figure 9 Falola, Fiki. Grades of Colonial Ground Gradient. 2021

Figure 10 Falola, Fiki. Holding Tanks for Water Gradient. 2021 
Figure 11 Falola, Fiki. Featured Maps in Document. 2021

Figure 12 Lagos 1885. (See List of Maps for Reference)

Figure 13 Falola, Fiki. Lagos 1885. 2020

Figure 14 Lagos 1962. (See List of Maps for Reference)

Figure 15 Falola, Fiki. Lagos 1962. 2020

Figure 14 Lagos 1977. (See List of Maps for Reference)

Figure 15 Falola, Fiki. Lagos 1977. 2020

Figure 17 Lagos 1981. (See List of Maps for Reference)

Figure 18 Falola, Fiki. Lagos 1981. 2020

Figure 19 Lagos 2020 (See List of Maps for Reference)

Figure 20 Falola, Fiki. Lagos 2020. 2020

Figure 21 Falola, Fiki. Comparison of Different Mapping Styles. 2021

Figure 22 Falola, Fiki. Conceptual Map Model. 2021

Figure 23 Falola, Fiki. Conceptual Map Model: Water. 2021

Figure 24 Falola, Fiki. Conceptual Map Model: Evaporation. 2021

Figure 25.1 Falola, Fiki. Conceptual Map Model: Aftermath, Material

absorbency. 2021

Figure 25.2 Falola, Fiki. Conceptual Map Model: Aftermath, Sediment and ink accumulated at base of tank. 2021

Figure 26 Falola, Fiki. Selected Area for Section. 2021
Figure 27 Falola, Fiki. Section 1- Canal, Apapa-Ajegunle. 2021

Figure 28 Falola, Fiki. Section 2-- Canal, Apapa-Ajegunle. 2021

Figure 29 Falola, Fiki. Section 3-The Wharf. 2021

Figure 30 Patent for Live Wood Wall. Hindle, Richard L. "Levees That Might Have Been." Places Journal, May 18, 2015. https://doi. org/10.22269/150518

Figure 31 Falola, Fiki. Exercises in Form Finding, Summary. 2021

Figure 32 Falola, Fiki. Exercise, "On Concrete Pipes". 2021

Figure 33 Falola, Fiki. Exercise, "On Concrete Pipes": Tank Experiment, Profile 1.2021

Figure 34 Falola, Fiki. Exercise, "On Concrete Pipes": Tank

Experiment, Profile 2. 2021

Figure 35 Falola, Fiki. Vegetative Pods: Assembly Process. 202

Figure 36 Falola, Fiki. Vegetative Pods: Tank Experiment. 2021

Figure 37 Falola, Fiki. Geoverse Tweet, LasGidi Lagoon. Twitter for Geoverse. 2021

Figure 38 Falola, Fiki. Geoverse Tweet, Great Wall of Lagos, The Atlantic, Utility-Cul. Twitter for Geoverse. 2021

Figure 39 Falola, Fiki. Fluid Futures, Collage. 2021

Figure 40 Falola, Fiki. Aggregate, Accrete Adapt Collage. 2021

Figure 41 Falola, Fiki. Ship Edge, Plan. 2021 
Figure 42 Falola, Fiki. Canal Edge, Plan. 2021

Figure 43 Falola, Fiki. Regrowing the Coastline, Plan. 2021

Figure 44 Falola, Fiki. Ship Edge (Berthed), Section. 2021

Figure 45 Falola, Fiki. Canal/Creek Edge, Section. 2021

Figure 46 Falola, Fiki. Bridge-Underside Edge, Section. 2021

Figure 47 Falola, Fiki. Communal Edge. 2021

Figure 48 Falola, Fiki. Mangrove Tweet, Geoverse Thread. Twitter for Geoverse. 2021

Figure 49 Falola, Fiki. The Atlantic et.al, Geoverse Thread. Twitter for Geoverse. 2021 
1 Dredging Today. "USA: DredgeFest Approaches," September 6, 2012. https://www.dredgingtoday.com/2012/09/06/usa-dredgefest-approaches/.

2 Thomas E. Dahl, and Gregory J. Allord. History of Wetlands in the Conterminous United States. U.S. Geological Survey, 1997.

3 Idowu, Ajibade. "Can a Future City Enhance Urban Resilience and Sustainability? A Political Ecology Analysis of Eko Atlantic City, Nigeria." International Journal of Disaster Risk Reduction, Africa's Urban Risk and Resilience, 26 (December 1, 2017): 85-92. https://doi org/10.1016/j.jjdrr.2017.09.029.

4 Lorena, Zárate. "They Are Not 'Informal Settlements'-They Are Habitats Made by People." The Nature of Cities (blog), April 26, 2016. https://www.thenatureofcities.com/2016/04/26/they-are-not-informal-settlements-they-are-habitats-made-by-people/. This idea was inspired by Lorena Zárate's concept- The Social Production of Habitat which details the production of habitat by people using people-centered processes to create and manage housing, services and community infrastructure. Lorena Zárate, President of Habitat International Coalition critiques the use of the term slum and its variations because it often highlights the negative aspects of such living conditions while ignoring their complexity and the rights of people to produce and manage their own habitats as a fundamental right to the city.

5 The term "New World" was historically used by European navigators to refer to issues concerning the exploration and colonization of the 
Americas. It was called the New World because previously, most exploration and known land had existed in Africa, Asia, and Europe. The term "New World" here, not to be confused with its historical use is placed in the context of architecture to describe new ground for architectural theorization and exploration that has not previously been rigorously studied or examined.

6 Anuradha Mathur and Dilip Da Cunha. Soak: Mumbai in an Estuary. New Delhi: Rupa Publications, 2009. In Soak, Dilip and Anuradha imagine Mumbai as an estuary rather than an island they note that an estuary demands gradients not walls, fluid occupancies not defined land uses, negotiated moments not hard edges.

7 In the essay "Why has Critique Run out of Steam? From Matters of Fact to Matters of Concern, Bruno Latour describes matters of concern as "... what happens to a matter of fact [indisputable and usually scientific facts,] when you add to it its whole scenography, much like you would do by shifting your attention from the stage to the whole machinery of a theatre..."(Latour, 39).

8 Melissa Lawford, "Lagos Homes Spill over on to Reclaimed Land," October 12, 2018, https://www.ft.com/content/80f4c41a-c71d-11e886e6-19f5b7134d1c

9 M. O. Ajibola, Adewale B. A. , and K. C. ljasan. "Effects of Urbanisation on Lagos Wetlands." International Journal of Business and Social Science 3, no. 17 (September 2012): 310-18.

10 Elisée Reclus and A. H. (Augustus Henry) Keane, The Earth and Its Inhabitants ... (New York, D. Appleton and company, 1882), http://archive.org/details/earthitsinhabita13recl_0.
11 Mathur and Da Cunha, 6

12 John, McPhee. "Atchafalaya." The New Yorker, February 16, 1987. https://www.newyorker.com/magazine/1987/02/23/atchafalaya. 13 Ayodeji Olukoju, "The Development of the Port of Lagos, c. 1892 1946 - Ayodeji Olukoju, 1992,” The Journal of Transport History, August 1, 2016, https://journals-sagepub-com.myaccess.library.utoronto.ca/ doi/10.1177/002252669201300105

14 Edward W. Soja, "History: Geography: Modernity," in Postmodern Geographies: The Reassertion of Space in Critical Social Theory, 2nd ed. edition (London New York, 2011), 21. Foucault's 'Eye of Power' is the preface to Jeremy Bentham's La Panotptique.

15 Ademide Adelusi-Adeluyi, "Mapping Old Lagos: Digital Histories and Maps about the Past," The Historian 82, no. 1 (January 2, 2020): 52, https://doi.org/10.1080/00182370.2020.1734725.

16 Thomas E. Dahl and Gregory J. Allord, History of Wetlands in the Conterminous United States (U.S. Geological Survey, 1997).

17 Anuradha Mathur and Dilip Da Cunha, Soak: Mumbai in an Estuary (New Delhi: Rupa Publications, 2009).

18 Mathur and $\mathrm{Da}$ Cunha, 4

19 Richard L. Hindle, "Levees That Might Have Been," Places Journal, May 18, 2015, https://doi. org/10.22269/150518.

\section{$20 \mathrm{lbid}$}

$21 \mathrm{lbid}$

22 Nnabugwu, Uluocha. "Fifty Years of Post-Colonial Mapping in Nigeria: An Overview." Cartographica: The International Journal for Geographic Information and Geovisualization 47, no. 3 (January 1, 2012): 
179-94. https://doi.org/10.3138/carto.47.3.1069, 188

23 Kye Whiteman, "The Topography of Lagos," in Lagos: A Cultural History (Interlink Publishing, 2013), 38.

24 Matthew Gandy, "Mosquitos, Modernity and Postcolonial Lagos," in The Fabric of Space: Water, Modernity, and the Urban Imagination (The MIT Press, 2014), 89.

$25 \mathrm{Ibid}, 83$

26 Whiteman, 35

27 Ibid, 37

28 In Lo-TEK. Design by Radical Idigenism, Julia Watson argues for Traditional Ecological Knowledge and living in symbiosis with nature, as a counterpractice to responding to climate change with hard infrastructures.

29 Should Trees Have Standing? - Toward Legal Rights for Natural Objects. Environmental Rights. Routledge, 2017. https://doi. org/10.4324/9781315094427-13, 286

30 Ibid, 291

31 Hindle, "Levees That Might Have Been"

32 lbid

33 lbid 
BIBLIOGRAPHY

Adeloye, Adebayo J., and Rabee Rustum. "Lagos (Nigeria) Flooding and Influence of Urban Planning." Proceedings of the Institution of Civil Engineers - Urban Design and Planning 164, no. 3 (September 1, 2011): 175-87. https://doi.org/10.1680/ udap.1000014.

Adelusi-Adeluyi, Ademide. "Mapping Old Lagos: Digital Histories and Maps about the Past." The Historian (Kingston) 82, no. 1 (2020):

51-65. https://doi.org/10.1080/00182370.2020.1734725.

Agrest, Diana, Peter L. Galison, Caroline A. Jones, D. Graham Burnett, and John Angus McPhee. Architecture of Nature: Nature of Architecture. Novato, CA: Applied Research \& Design, 2019.

Ajibade, Idowu. "Can a Future City Enhance Urban Resilience and Sustainability? A Political Ecology Analysis of Eko Atlantic City, Nigeria." International Journal of Disaster Risk Reduction, Africa's Urban Risk and Resilience, 26 (December 1, 2017): 85-92. https:// doi.org/10.1016/j.j.jdrr.2017.09.029.

Ajibola, M. O., B. A. Adewale, and K. C. ljasan. "Effects of Urbanisation on Lagos Wetlands." International Journal of Business and Social Science 3, no. 17 (September 2012): 310-18.

Falola, Toyin, and Matthew M. Heaton. A History of Nigeria. Cambridge, UK ; New York: Cambridge University Press, 2008.

Food and Agriculture Organization of the United Nations. "Mangrove Management." Accessed October 4, 2020. http://www.fao.org/ 
forestry/mangrove/vegetation/en/nga/.

Gandy, M. "Learning from Lagos." Gandy, M. (2005) Learning from Lagos. New Left Review, 33 . Pp. 37-53. ISSN 0028606033 (June $1,2005)$

Gandy, Matthew. "Planning, Anti-Planning and the Infrastructure Crisis Facing Metropolitan Lagos." Urban Studies 43, no. 2 (2006): $371-96$.

Gandy, Matthew. The Fabric of Space: Water, Modernity, and the Urban Imagination. The MIT Press, 2014. https://www.jstor.org/stable/j. ctt9qf9xf.

Hindle, Richard L., "Levees That Might Have Been," Places Journal, May 18, 2015, https://doi.org/10.22269/150518.

Koolhaas, Rem; Boeri Stefano; Kwinter Sanford; Fabricius Daniela; Obrist Hans Ulrich ; Tazi Nadia. MUTATIONS. Barcelona: ACTAR, Arc-en-Rêve, 2000.

Lawford, Melissa. "Lagos Homes Spill over on to Reclaimed Land," October 12, 2018. https://www.ft.com/content/80f4c41a-c71d11e8-86e6-19f5b7134d1c

Latour, Bruno. "Why Has Critique Run out of Steam? From Matters of Fact to Matters of Concern." Critical Inquiry 30, no. 2 (January 1, 2004): 225-48. https://doi.org/10.1086/421123.

Mathur, Anuradha, and Dilip Da Cunha. Soak: Mumbai in an Estuary. New Delhi: Rupa Publications, 2009
McPhee, John. "Atchafalaya." The New Yorker, February 16, 1987. https://www.newyorker.com/magazine/1987/02/23/atchafalaya.

Mendelsohn, Ben. "Making the Urban Coast. A Geosocial Reading of Land, Sand, and Water in Lagos, Nigeria." Comparative Studies of South Asia, Africa and the Middle East 38, no. 3 (December 1, 2018) 455-72. https://doi.org/10.1215/1089201x-7208801.

Nigeria. Federal Surveys (1960). Nigeria 1:12,500: Lagos \& environs (5th ed). Federal Surveys, [Lagos]

Nkwunonwo, U., M. Whitworth, and B. Baily. "Review Article: A Review and Critical Analysis of the Efforts towards Urban Flood Risk Management in the Lagos Region of Nigeria," 2016. https://doi. org/10.5194/NHESS-16-349-2016.

Odume, Nelson. "Lagos Is Getting Less Rain, but More Heavy Storms. What lt Can Do to Prepare." The Conversation. Accessed August 12, 2020. http://theconversation.com/lagos-is-getting-less-rain-butmore-heavy-storms-what-it-can-do-to-prepare-134437.

Olukoju, Ayodeji. "The Development of the Port of Lagos, c. 1892 1946 - Ayodeji Olukoju, 1992." The Journal of Transport History, August 1, 2016.

Reclus, Elisée, and A. H. (Augustus Henry) Keane. The Earth and lts Inhabitants... New York, D. Appleton and company, 1882. http:// archive.org/details/earthitsinhabita13recl_0

Stone, Christopher D. Should Trees Have Standing? - Toward Legal Rights for Natural Objects. Environmental Rights. Routledge, 2017. 
https://doi.org/10.4324/9781315094427-13

Thomas E. Dahl and Gregory J. Allord, History of Wetlands in the Conterminous United States (U.S. Geological Survey, 1997).

Uluocha, Nnabugwu. "Fifty Years of Post-Colonial Mapping in Nigeria: An Overview." Cartographica: The International Journal for Geographic Information and Geovisualization 47, no. 3 (January 1, 2012): 179-94. https://doi.org/10.3138/carto.47.3.1069.

Watson, Julia, W. -E. studio, and Taschen. Julia Watson. Lo-TEK, De sign by Radical Indigenism. Taschen, 2020. 